Prepared in cooperation with the

Charles County Department of Planning and Growth Management Maryland Department of the Environment

Maryland Geological Survey

\title{
Summary and Interpretation of Discrete and Continuous Water-Quality Monitoring Data, Mattawoman Creek, Charles County, Maryland, 2000-11
}

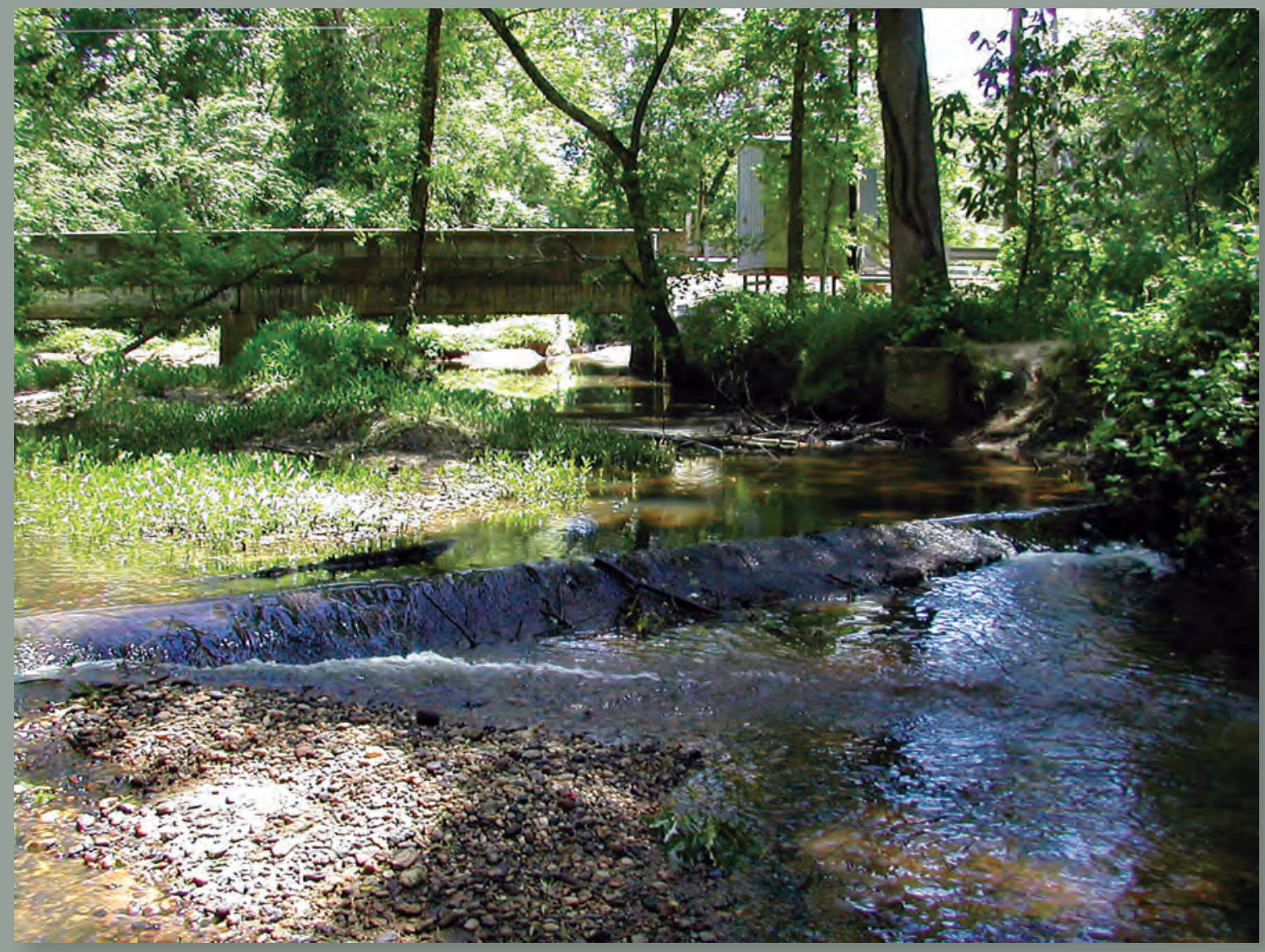

Scientific Investigations Report 2012-5265

U.S. Department of the Interior

U.S. Geological Survey 
Cover. View of Mattawoman Creek looking upstream at the U.S. Geological Survey (USGS) streamgaging station 01658000 near Pomfret Road, Charles County, Maryland. [Photograph taken June 2010 by David P. Brower, USGS.] 


\section{Summary and Interpretation of Discrete and Continuous Water-Quality Monitoring Data, Mattawoman Creek, Charles County, Maryland, 2000-11}

By Jeffrey G. Chanat, Cherie V. Miller, Joseph M. Bell, Brenda Feit Majedi, and David P. Brower

Prepared in cooperation with the Charles County Department of Planning and Growth Management Maryland Department of the Environment Maryland Geological Survey

Scientific Investigations Report 2012-5265 


\section{U.S. Department of the Interior \\ KEN SALAZAR, Secretary \\ U.S. Geological Survey \\ Marcia K. McNutt, Director}

U.S. Geological Survey, Reston, Virginia: 2013

For more information on the USGS - the Federal source for science about the Earth, its natural and living resources, natural hazards, and the environment, visit http://www.usgs.gov or call 1-888-ASK-USGS

For an overview of USGS information products, including maps, imagery, and publications, visit http://www.usgs.gov/pubprod

To order this and other USGS information products, visit http://store.usgs.gov

Any use of trade, product, or firm names is for descriptive purposes only and does not imply endorsement by the U.S. Government.

Although this report is in the public domain, permission must be secured from the individual copyright owners to reproduce any copyrighted materials contained within this report.

Suggested citation:

Chanat, J.G., Miller, C.V., Bell, J.M., Majedi, B.F., and Brower, D.P., 2013, Summary and interpretation of discrete and continuous water-quality monitoring data, Mattawoman Creek, Charles County, Maryland, 2000-11:

U.S. Geological Survey Scientific Investigations Report 2012-5265, 42 p. 


\section{Contents}

Abstract

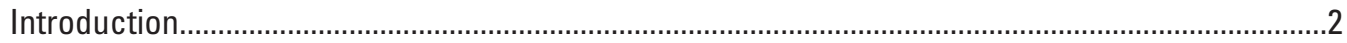

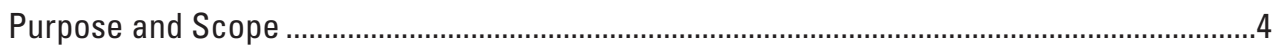

Description of Mattawoman Creek and Watershed ……….....................................................

Description of Comparison Basins ............................................................................................

Choptank River near Greensboro, Maryland, U.S. Geological Survey

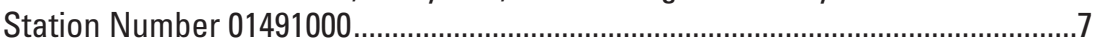

North Branch Patapsco River at Cedarhurst, Maryland, U.S. Geological

Survey Station Number 01586000 .........................................................................

Georges Creek at Franklin, Maryland, U.S. Geological Survey Station

Number 01599000 ...............................................................................................

Northwest Branch Anacostia River near Hyattsville, Maryland,

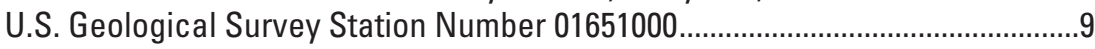

Potomac River at Chain Bridge, U.S. Geological Survey Station Number

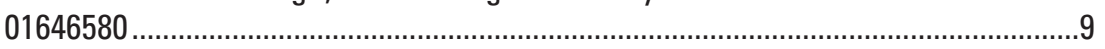

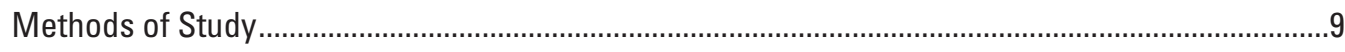

Measurements of Continuous Flow and Water Quality.......................................................

Field Collection of Discrete Water-Quality Samples...............................................................

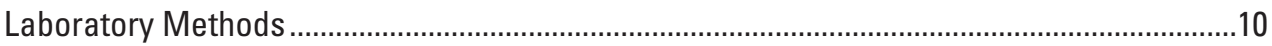

Regression Models for Nutrients and Sediment ..................................................................11

Estimates of Loads and Yields ............................................................................................11

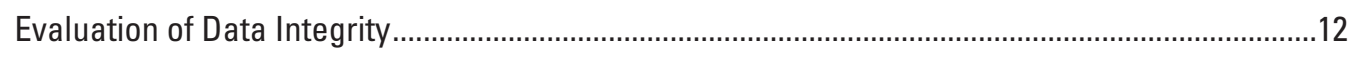

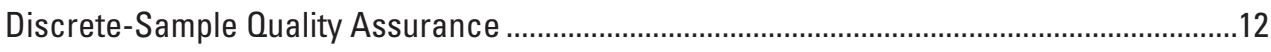

Constituents Computed by Difference .....................................................................................

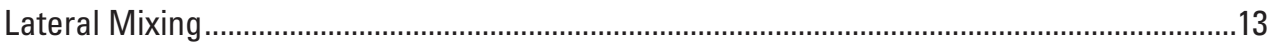

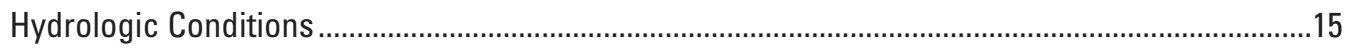

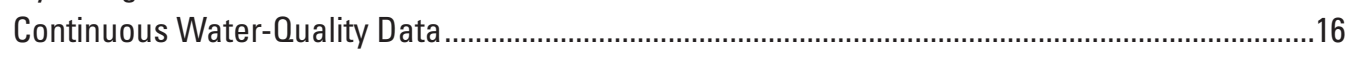

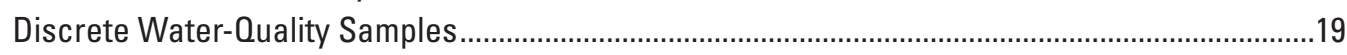

Corresponding Range of Continuous Conditions .................................................................

Suspended-Sediment and Nutrient Concentrations..............................................................19

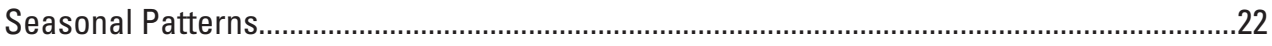

Interrelations between Physical Parameters, Nutrients, and Suspended Sediment ............24

Comparisons between Watersheds_Concentration Data ..................................................26

Estimation of Continuous Concentrations of Nutrients and Suspended Sediment .........................26

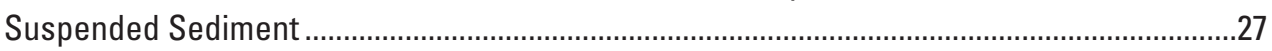

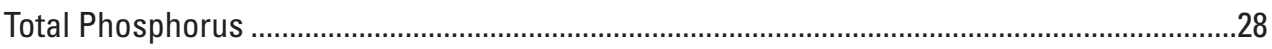

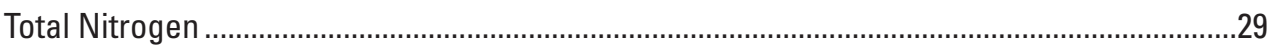

Estimation of Nutrient and Suspended-Sediment Loads and Yields.............................................30

Comparisons between Watersheds_-Load Estimates.............................................................3

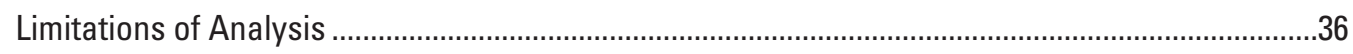

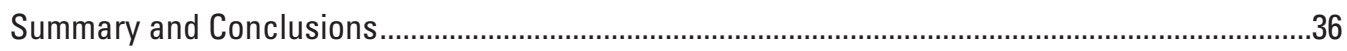

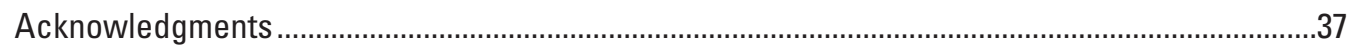

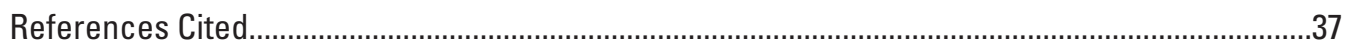

Appendix A1: Relations between Measured Water-Quality Parameters and Constituents Discussed in this Report................................................................................41 


\section{Figures}

1. Map showing location of Mattawoman Creek watershed study area...

2. Graphs showing $(A)$ median monthly precipitation for lower southern Maryland (Charles, St. Mary's, and Calvert Counties), and (B) discharge at Mattawoman Creek for water years 1951-71 and 2002-10..

3. Map showing land cover in the Mattawoman Creek watershed, 2006 .6

4. Aerial orthophotograph of the gage location showing location of main channel braids and the mouth of Old Womans Run relative to the location of the gage, continuous water-quality sonde, and sampler intake, 2007

5. Graph showing example storm hydrographs for a 3-week period in 2004 at Mattawoman Creek showing varying degrees of influence of inflow from Old Womans Run on the shape of the hydrograph rising limb .14

6. Graphs showing examples of concurrent 15-minute data collected by the operational water-quality sonde at left-edge water (presumed to be influenced by Old Womans Run) and the temporary sonde (Sonde 2) deployed in 2011 in the center of the rightmost bridge culvert (presumed to be primarily representative of the Mattawoman Creek main channel) $(A)$ specific conductance, $(B)$ turbidity, and $(C)$ discharge

7. Graphs showing difference in specific conductance and turbidity between the operational sonde mounted at left-edge water (presumed to be influenced by Old Womans Run) and the temporary sonde (Sonde 2) deployed in 2011 in the center of the rightmost bridge culvert (presumed to be primarily representative of the Mattawoman Creek main channel). $(A)$ specific conductance, (B) turbidity, and (C) discharge

8. Graphs showing hydrologic conditions at Mattawoman Creek, water years 2002-10 (A) Annual precipitation for southern Maryland, $(B)$ mean annual discharge, (C) monthly distribution of days with flow greater than 400 cubic feet per second (overbank at gage), and (D) monthly distribution of days with no measureable flow

9. Graphs showing monthly variation in 15-minute observations collected by the continuous water-quality sonde, Mattawoman Creek, 2003-10 $(A)$ discharge, $(B)$ turbidity, $(C)$ temperature, $(D)$ dissolved oxygen, (E) $\mathrm{pH}$, and (F) specific conductance

10. Graphs showing cumulative frequency distributions of 15-minute discharge and water-quality sonde data, showing median parameter values (dots) and parameter ranges (whiskers) corresponding to collection of discrete water-quality samples $(A)$ discharge, $(B)$ turbidity, $(C)$ temperature, $(D)$ dissolved oxygen, $(E) \mathrm{pH}$, and (F) specific conductance.

11. Boxplots showing monthly variation in continuous discharge observations at times corresponding to collection of discrete water-quality samples, Mattawoman Creek, 2001-10..

12. Boxplots showing monthly variation in suspended-sediment concentrations, discrete water-quality samples, Mattawoman Creek, 2001-10.

13. Boxplots showing monthly variation in total phosphorus concentrations, discrete water-quality samples, Mattawoman Creek, 2001-10.

14. Boxplots showing monthly variation in total nitrogen concentrations, discrete water-quality samples, Mattawoman Creek, 2001-10.

15. Graph showing monthly variation in median concentrations of major phosphorus species, Mattawoman Creek, 2001-10 
16. Graph showing monthly variation in median concentrations of major nitrogen species, Mattawoman Creek, 2001-10...

17. Boxplots comparing distributions of concentration data from Mattawoman Creek with data from four comparison watersheds, and the Potomac River, 2000-10 (A) suspended sediment (total suspended solids for Georges Creek and Patapsco River, $(B)$ total phosphorus, and $(C)$ total nitrogen

18. Graph showing comparison of observed suspended-sediment concentrations at Mattawoman Creek with values predicted by model equation shown in table 4

19. Graph showing comparison of observed total phosphorus concentrations at Mattawoman Creek with values predicted by model equation shown in table 4

20. Graph showing comparison of observed total nitrogen concentrations at Mattawoman Creek with values predicted by model equation shown in table 4

21. Graphs showing LOADEST estimates of flux for suspended sediment, total phosphorus, and total nitrogen, Mattawoman Creek, water years 2002-10, comparing estimates based on daily and hourly time steps. Whiskers indicate 95-percent confidence intervals $(A)$ suspended sediment, $(B)$ total phosphorus, and $(C)$ total nitrogen.

22. Graphs showing time series of discharge, turbidity, and LOADEST estimates of suspended-sediment flux for a 10-day period in January 2009 comparing time series of load estimates based on a daily model with discharge, an hourly model with discharge, and an hourly model with discharge and turbidity $(A)$ discharge and turbidity, and

(B) load estimates 


\section{Tables}

1. Station location, size, and land cover for Mattawoman Creek, four similarly sized comparison basins, and the Potomac River.... .8

2. Constituent summary statistics for discrete water-quality samples collected at Mattawoman Creek, October 2000 through January 2011

3. Pearson correlation coefficients between and among physical waterquality parameters, nutrients, and suspended sediment,

Mattawoman Creek.

4. Regression models for concentrations of suspended sediment, total phosphorus, and total nitrogen, Mattawoman Creek, with corresponding models for Northeast and Northwest Branches of the Anacostia River near Washington, D.C.

5. Comparison of annual loading estimates made during this study with estimates made in 2010 by the U.S. Geological Survey for Mattawoman Creek as a component of the Chesapeake Bay Program Nontidal Monitoring Network (NTN)

6. Regression model coefficients (p-values), and model performance statistics for LOADEST models, comparing models constructed using seven parameters with models constructed using turbidity as an eighth parameter

7. Total loading estimates and model prediction uncertainty for the period January 6-March 6, 2009, comparing LOADEST models constructed using discharge with daily data, discharge with hourly data, and discharge and turbidity with hourly data

8. Annual yields of suspended sediment, total nitrogen, and total phosphorus for the 2008 water year (October 1, 2007-September 30, 2008) for Mattawoman Creek, four comparison watersheds, and the Potomac River 


\section{Conversion Factors}

\begin{tabular}{|c|c|c|}
\hline Multiply & By & To obtain \\
\hline \multicolumn{3}{|c|}{ Length } \\
\hline inch (in.) & 2.54 & centimeter $(\mathrm{cm})$ \\
\hline foot $(\mathrm{ft})$ & 0.3048 & meter $(\mathrm{m})$ \\
\hline mile (mi) & 1.609 & kilometer $(\mathrm{km})$ \\
\hline \multicolumn{3}{|c|}{ Area } \\
\hline acre & 0.004047 & square kilometer $\left(\mathrm{km}^{2}\right)$ \\
\hline square mile $\left(\mathrm{mi}^{2}\right)$ & 2.590 & square kilometer $\left(\mathrm{km}^{2}\right)$ \\
\hline \multicolumn{3}{|c|}{ Volume } \\
\hline ounce, fluid (fl. oz) & 0.02957 & liter (L) \\
\hline gallon (gal) & 3.785 & liter (L) \\
\hline cubic inch $\left(\right.$ in $\left.^{3}\right)$ & 0.01639 & liter (L) \\
\hline cubic foot $\left(\mathrm{ft}^{3}\right)$ & 0.02832 & cubic meter $\left(\mathrm{m}^{3}\right)$ \\
\hline \multicolumn{3}{|c|}{ Flow rate } \\
\hline inch per year (in/yr) & 25.4 & millimeter per year (mm/yr) \\
\hline cubic foot per second $\left(\mathrm{ft}^{3} / \mathrm{s}\right)$ & 0.02832 & cubic meter per second $\left(\mathrm{m}^{3} / \mathrm{s}\right)$ \\
\hline cubic meter per second $\left(\mathrm{m}^{3} / \mathrm{s}\right)$ & 22.83 & million gallons per day (Mgal/d) \\
\hline \multicolumn{3}{|c|}{ Mass } \\
\hline ounce, avoirdupois (oz) & 28.35 & $\operatorname{gram}(\mathrm{g})$ \\
\hline pound, avoirdupois (lb) & 0.4536 & kilogram $(\mathrm{kg})$ \\
\hline \multicolumn{3}{|c|}{ Concentration } \\
\hline milligrams per liter (mg/L) & $1,000 \mathrm{n} / \mathrm{m}^{*}$ & microequivalents per liter $(\mu \mathrm{eq} / \mathrm{L})$ \\
\hline \multicolumn{3}{|c|}{ Yield } \\
\hline $\begin{array}{l}\text { pound per year per square mile } \\
\left(\mathrm{lb} / \mathrm{yr} / \mathrm{mi}^{2}\right)\end{array}$ & 0.1751 & $\begin{array}{l}\text { kilogram per year per square } \\
\text { kilometer }\left(\mathrm{kg} / \mathrm{yr} / \mathrm{km}^{2}\right)\end{array}$ \\
\hline
\end{tabular}

Temperature in degrees Celsius $\left({ }^{\circ} \mathrm{C}\right)$ may be converted to degrees Fahrenheit $\left({ }^{\circ} \mathrm{F}\right)$ as follows:

$$
{ }^{\circ} \mathrm{F}=\left(1.8 \mathrm{x}^{\circ} \mathrm{C}\right)+32
$$

Specific conductance is given in microsiemens per centimeter at 25 degrees Celsius $(\mu \mathrm{S} / \mathrm{cm}$ at $\left.25^{\circ} \mathrm{C}\right)$.

Concentrations of chemical constituents in water are given either in milligrams per liter (mg/L) or micrograms per liter $(\mu \mathrm{g} / \mathrm{L})$.

Concentrations of chemical constituents on suspended particulates are given in milligrams per kilogram $(\mathrm{mg} / \mathrm{kg})$ of dry weight of the suspended particles.

Units of turbidity are given in formazin turbidity units (FNU), which are nephelometric turbidity units based on a formazin standard.

Water year is the 12-month period starting October 1, and ending September 30 of the following year. 



\title{
Summary and Interpretation of Discrete and Continuous Water-Quality Monitoring Data, Mattawoman Creek, Charles County, Maryland, 2000-11
}

\author{
By Jeffrey G. Chanat, Cherie V. Miller, Joseph M. Bell, Brenda Feit Majedi, and David P. Brower
}

\section{Abstract}

Discrete samples and continuous (15-minute interval) water-quality data were collected at Mattawoman Creek (U.S. Geological Survey station number 01658000) from October 2000 through January 2011, in cooperation with the Charles County (Maryland) Department of Planning and Growth Management, the Maryland Department of the Environment, and the Maryland Geological Survey. Mattawoman Creek is a fourth-order Maryland tributary to the tidal freshwater Potomac River; the creek's watershed is experiencing development pressure due to its proximity to Washington, D.C. Data were analyzed for the purpose of describing ambient water quality, identifying potential contaminant sources, and quantifying nutrient and sediment loads to the tidal freshwater Mattawoman estuary. Continuous data, collected at 15-minute intervals, included discharge, derived from stage measurements made using a pressure transducer, as well as water temperature, $\mathrm{pH}$, specific conductance, dissolved oxygen, and turbidity, all measured using a waterquality sonde. In addition to the continuous data, a total of 360 discrete water-quality samples, representative of monthly low-flow and targeted storm conditions, were analyzed for suspended sediment and nutrients. Continuous observations gathered by a second water-quality sonde, which was temporarily deployed in 2011 for quality-control purposes, indicated substantial lateral water-quality gradients due to inflow from a nearby tributary, representing about 10 percent of the total gaged area upstream of the sampling location. These lateral gradients introduced a time-varying bias into both the continuous and discrete data, resulting in observations that were at some times representative of water-quality conditions in the main channel and at other times biased towards conditions in the tributary. Despite this limitation, both the continuous and discrete data provided insight into the watershed-scale factors that influence water quality in Mattawoman Creek.

Annual precipitation over the study period was representative of the long-term record for southern Maryland. The median value of continuously measured discharge was 25 cubic feet per second $\left(\mathrm{ft}^{3} / \mathrm{s}\right)$, and the maximum observed value was $3,210 \mathrm{ft}^{3} / \mathrm{s}$; there were 498 days, or about 15 percent of the study period, when flow was zero or too low to measure. Continuously measured water temperature followed a seasonal trend characteristic of the geographic setting; the trend in dissolved oxygen was inverted relative to temperature, and reflected nearly saturated conditions year round. Relations between discharge and both $\mathrm{pH}$ and specific conductance indicate that stream water can be conceptualized as a mixture of acidic, dilute precipitation with $\mathrm{pH}$-neutral groundwater of higher conductance. Specific conductance data showed a pronounced winter peak in both median and extreme measurements, indicating the influence of road salt. However, this influence is minor relative to that observed in the Northeast Branch Anacostia River (U.S. Geological Survey station number 01649500 ), a nearby, more heavily urbanized comparison basin.

The median suspended-sediment concentration in discrete samples was 24 milligrams per liter $(\mathrm{mg} / \mathrm{L})$, with minimum and maximum concentrations of $1 \mathrm{mg} / \mathrm{L}$ and 2,890 mg/L, respectively. Total nitrogen ranged from $0.21 \mathrm{mg} / \mathrm{L}$ to 4.09 $\mathrm{mg} / \mathrm{L}$, with a median of $0.69 \mathrm{mg} / \mathrm{L}$; total phosphorus ranged from less than $0.01 \mathrm{mg} / \mathrm{L}$ to $0.98 \mathrm{mg} / \mathrm{L}$, with a median of 0.07 $\mathrm{mg} / \mathrm{L}$. Total nitrogen was dominated by the dissolved organic fraction (49 percent based on median species concentrations); total phosphorus was predominantly particulate (70 percent). Seasonal trends in suspended-sediment concentration indicate a supply subsidy in late winter and spring; this could be linked to flood-plain interaction, mobilization of sediment from the channel or banks, or anthropogenic input. Seasonal trends for both total phosphorus and total nitrogen generally corresponded to seasonal trends for suspended sediment, indicating a common underlying physical control, likely acting in synchrony with seasonal biological controls on total nutrient concentrations. Speciation of phosphorus, including proportional concentration of the biologically available dissolved inorganic fraction, did not vary seasonally. The speciation of nitrogen reflected demand for inorganic nitrogen and associated transformation into organic nitrogen during the growing season. 
Stepwise regression models were developed, using continuous data corresponding to collection times for discrete samples as candidate surrogates for suspended sediment, total phosphorus, and total nitrogen. Turbidity and discharge were both included in the model for suspended sediment $\left(\mathrm{R}^{2}=0.76\right.$, $\mathrm{n}=185)$; only turbidity was selected as a robust predictor of total phosphorus and nitrogen $\left(\mathrm{R}^{2}=0.68\right.$ and 0.61 , respectively, $\mathrm{n}=186$ for both). Loads of sediment and nutrients to the downstream Mattawoman estuary were computed using the U.S. Geological Survey computer program LOADEST. Load estimation included comparison of a routinely applied seven-parameter regression model based on time, season, and discharge, with an eight-parameter model that also includes turbidity. Adding turbidity decreased total load estimates, based on hourly data for a fixed 2-month period, by 21,8 , and 3 percent for suspended sediment, total phosphorus, and total nitrogen, respectively, in addition to decreasing the standard error of prediction for all three constituents.

The seasonal pattern in specific conductance, reflecting road salt application, is the strongest evidence of the effect of upstream development on water quality at Mattawoman Creek. Accordingly, ongoing continuous monitoring for trends in specific conductance would be the most reliable means of detecting further degradation associated with increased development.

\section{Introduction}

Effective watershed management requires a comprehensive understanding of hydrology and water quality in addition to geography and land use within a watershed. Mattawoman Creek, a tributary of the tidal freshwater Potomac River, drains 93.8 square miles $\left(\mathrm{mi}^{2}\right)$ in the Coastal Plain of southern Maryland (fig. 1). Although the watershed is predominantly forested, it is becoming urbanized due to its proximity to the Washington, D.C. urban corridor. The creek is regionally recognized as one of the most pristine Coastal Plain Chesapeake Bay tributaries of comparable size; it provides an important spawning ground for anadromous fish, a thriving sport fishery, habitat for a wide variety of terrestrial and aquatic organisms, and numerous recreational opportunities (Denny, 2009). However, as one of the least-developed areas within comparable commuting time of Washington, D.C., the watershed is changing rapidly: growth rates in Charles County, where most of the watershed lies, were 21.6 percent between 2000 and 2010, compared to 9.0 percent for the entire State of Maryland for the same period (U.S. Census Bureau, 2011). The creek is listed on Maryland's 303(d) list, the mechanism for reporting the regulatory status of the State's waters to the U.S. Environmental Protection Agency, as impaired for nutrients and sediment. The Charles County Department of Planning and Growth Management is developing a comprehensive management plan with a major focus on preservation of Mattawoman Creek and its watershed. Major technical recommendations of a 2003 study by the U.S. Army Corps of Engineers, commissioned by Charles County, include protecting the stream valley from development, using low-impact development (LID) with distributed stormwater management, and retrofitting existing stormwater conveyance facilities to the maximum extent practical (U.S. Army Corps of Engineers, 2003).

Some of the most challenging problems in the field of watershed science involve quantifying the mass flux, or load, of sediment and nutrients leaving a watershed, as well as identifying both the sources of sediment and nutrients and the transformations that they undergo during transport. These sources and transformations can vary substantially, even between neighboring watersheds in areas of relatively undisturbed land use, due to factors evident only with detailed study (Böhlke and Denver, 1995; Feller, 2009). Sediment and nutrient fluxes typically increase with urbanization (Paul and Meyer, 2001; Walsh and others, 2005). However, the magnitude and timing of these increases, as well as the potential for transformation, is highly dependent on site-specific factors such as the presence of wastewater treatment plant discharge, type of wastewater treatment, design and age of retention and conveyance infrastructure, land use preceding urbanization, and watershed hydrology and lithology (Paul and Meyer, 2001). These factors complicate the separation of land-use impacts from variability in natural watershed processes.

Weller and others (2003) presented evidence that watersheds in the Atlantic Coastal Plain are generally more sensitive to development impacts than those in the Piedmont Province to the west. Ator and others (2011) constructed and interpreted an empirical model of the factors influencing nitrogen and phosphorus loading throughout the Chesapeake Bay watershed. They identified the Coastal Plain in general as a source of excess phosphorus, and speculated that this could be the effect of historical agricultural application; legacy phosphorus associated with agriculture can be re-mobilized if agricultural land is subsequently re-developed (Paul and Meyer, 2001). Ator and others (2011) also found that both local vegetation, indicative of the potential for nitrogen uptake, and the available water capacity of local soil, a proxy for denitrifying conditions, influenced nitrogen loadings. They also found that the percentage of total nitrogen input attributable to atmospheric deposition for larger watersheds ranged from 10 to 31 ; locally the significance of atmospheric sources depended largely on the presence of other sources, especially point sources and agriculture. Considering the Bay watershed as a whole, Ator and others (2011) estimated that 27 percent of atmospheric nitrogen input reaches streams.

Mattawoman Creek has been the subject of a number of water-quality research studies. Hall and others (1993) conducted a study relating stream-water acidity to juvenile fish mortality in three Maryland Coastal Plain streams, including Mattawoman Creek. They found that the streams were only moderately buffered against acidic atmospheric inputs, and that in some cases, critical acidic conditions in these streams coincided with the presence of several species' susceptible 




Figure 1. Location of Mattawoman Creek watershed study area.

life stages. The Smithsonian Environmental Research Center (SERC) conducted a study in 1998-99 to assess current conditions, define nonpoint sources of nutrients and sediment, and project future conditions under different development scenarios (Jordan and others, 2000). Noe and Hupp (2007) investigated the role of the Mattawoman flood plain as a source, sink, or transformer of nutrients in four short-duration overbank flooding events. They noted that when forested flood plains are inundated for weeks to months, they are generally found to reduce inorganic nitrogen and increase organic nitrogen. However, they found less consistent patterns for short floods at Mattawoman, with substantial variability depending on season and flood magnitude. Gellis and others (2009) conducted a broad-scale study of sediment sources in the Chesapeake Bay watershed; Mattawoman Creek was among three small tributaries where they applied a "sediment fingerprinting" approach to associate water-column sediment with specific watershed sources. They found the streambanks and forest floor to be the likely dominant sources of suspended sediment at Mattawoman, but found that sediment characteristic of construction sites accounted for roughly a quarter of the total load in one of six storm events sampled.

The U.S. Geological Survey (USGS) has maintained a streamgage (USGS station number 01658000) on Mattawoman Creek near Pomonkey, Maryland, with support from the Maryland Department of the Environment (2001-02) and the Maryland Geological Survey (2003 to present). Starting in 2000, this station was used in a 2-year USGS study of water-quality conditions in the Potomac River watershed. The Charles County Department of Planning and Growth 
Management has supported continued collection of nutrient and suspended-sediment data at the station since 2003, for the purpose of characterizing ambient water quality, quantifying nutrient and sediment loading to the downstream estuarine part of Mattawoman Creek, and identifying water-quality conditions that might be indicative of impacts associated with increased development in the watershed. In 2003, the USGS added 15-minute water-quality monitoring for temperature, specific conductance, $\mathrm{pH}$, turbidity, and dissolved oxygen at this station. The USGS has collected over 10 years of data at this station since October 2000, and data collection is ongoing.

\section{Purpose and Scope}

The purpose of this report is to summarize and interpret the discrete and continuous data collected between October 2000 and January 2011 at USGS station 01658000 on the nontidal part of Mattawoman Creek in relation to the watershed's geographic setting, hydrology, and land use. Specifically, the report provides:

1. an analysis and interpretation of nitrogen, phosphorus, and suspended-sediment data with inferences related to watershed geography, runoff processes, and potential sources of water-quality impairments;

2. regression models to estimate concentrations of total nitrogen, total phosphorus, and suspended sediment using continuously measured surrogates including discharge, water temperature, $\mathrm{pH}$, specific conductivity, dissolved oxygen, and turbidity;

3. estimates of total nitrogen, total phosphorus, and suspended sediment loading to the Mattawoman estuary; and

4. a comparison of results for Mattawoman Creek with five other Chesapeake Bay tributaries, in terms of both ambient water quality and downstream loading.

\section{Description of Mattawoman Creek and Watershed}

The Mattawoman Creek watershed encompasses $93.8 \mathrm{mi}^{2}$ within the Atlantic Coastal Plain Physiographic Province in Charles and Prince George's Counties, Maryland (fig. 1). The creek valley is incised into the Waldorf Upland Plain District, a series of alluvial plains and fluvial-estuarine terraces that make up the higher elevations of southern Maryland (Reger and Cleaves, 2008). Predominant soils are porous silts and fine sandy loams of the Beltsville, Leonardtown, and Sassafras Soil series, atop interbedded sequences of upland gravel, sand, and cobbles (Hack, 1955; McCartan, 1989; Glaser, 2003; Hall and Mathews, 1974). The broad, flat flood plain, which represents the sediment-choked inland extension of the Mattawoman estuary, is separated from the upland by slopes typically exceeding 15 percent (U.S. Army Corps of Engineers, 2003). The creek is a fourth-order tributary of the tidal freshwater Potomac River, originating in forested wetlands in the vicinity of Brandywine, Maryland, and flowing southwest roughly 20 miles (mi) into a 7-mi-long tidal estuary with its mouth near Indian Head, Maryland (fig. 1).

Regionally, southern Maryland has a humid continental climate characterized by large seasonal temperature differences and generally evenly distributed annual precipitation. The 30-year normal mean annual temperature for lower southern Maryland (National Climatic Data Center Climate Division 3; Charles, St. Mary's, and Calvert Counties) for the period 1971-2000 was 55.6 degrees Fahrenheit $\left({ }^{\circ} \mathrm{F}\right)$, with a standard deviation of 1.0 degrees; the coldest and warmest months are January and July, respectively, with 30-year normal mean temperatures of 34.0 and 76.3 degrees, respectively (National Climatic Data Center, 2002a). The 30-year normal mean annual rainfall for the same region and period was 44.75 inches (in.) with a standard deviation of 6.98 in. Month-to-month, normal mean precipitation varied only slightly more than an inch, with the driest and wettest months being February (3.02 in.) and March (4.31 in.), respectively (National Climatic Data Center, 2002b).

The discharge and water-quality monitoring station on Mattawoman Creek (USGS station number 01658000), located off Route 227 near Pomonkey, Maryland, measures flow from a gaged area of $54.8 \mathrm{mi}^{2}$ (fig. 1). Daily discharge data were collected between 1950 and 1972, and again beginning in January 2001, when this study began. Mean annual discharge for this entire period, through water year 2010, was 58.1 cubic feet per second $\left(\mathrm{ft}^{3} / \mathrm{s}\right)$. Despite the nearly even distribution of monthly precipitation over this period, seasonal evapotranspiration resulted in marked seasonality in mean monthly discharge, with median values highest in March (114 $\left.\mathrm{ft}^{3} / \mathrm{s}\right)$ and lowest in September (2.34 ft $\mathrm{ft}^{3} / \mathrm{s}$; fig. 2). Periods of zero flow frequently occurred during the summer; the 25 th percentile for mean monthly flows for the months July through October is less than $2 \mathrm{ft}^{3} / \mathrm{s}$.

Predominant land cover in the gaged part of the watershed in 2006 was forest (47 percent), urban (28 percent), and forested wetland (12 percent; Fry and others, 2011) (fig. 3). The highest-density urban development occurs in the upper half of the watershed on the south side of the creek main stem, along the U.S. Route 301 corridor between Waldorf and St. Charles. The primary source of water for this developed area is groundwater: Charles County withdrew roughly 12 million gallons per day (Mgal/d) in 2005 (Charles County Department of Planning and Growth Management, 2006). The Waldorf water-supply system is the largest in the County, with a total of 16 wells tapping the confined Magothy and Patapsco aquifers. Most of the developed area above the gage is served by the Mattawoman Sewer Service Area (MSSA). This wastewater is treated at the Mattawoman Wastewater Treatment Plant, downstream of the gage, and discharged directly to the Potomac River; there are no permitted point wastewater discharges in the gaged area. However, it is estimated that there 

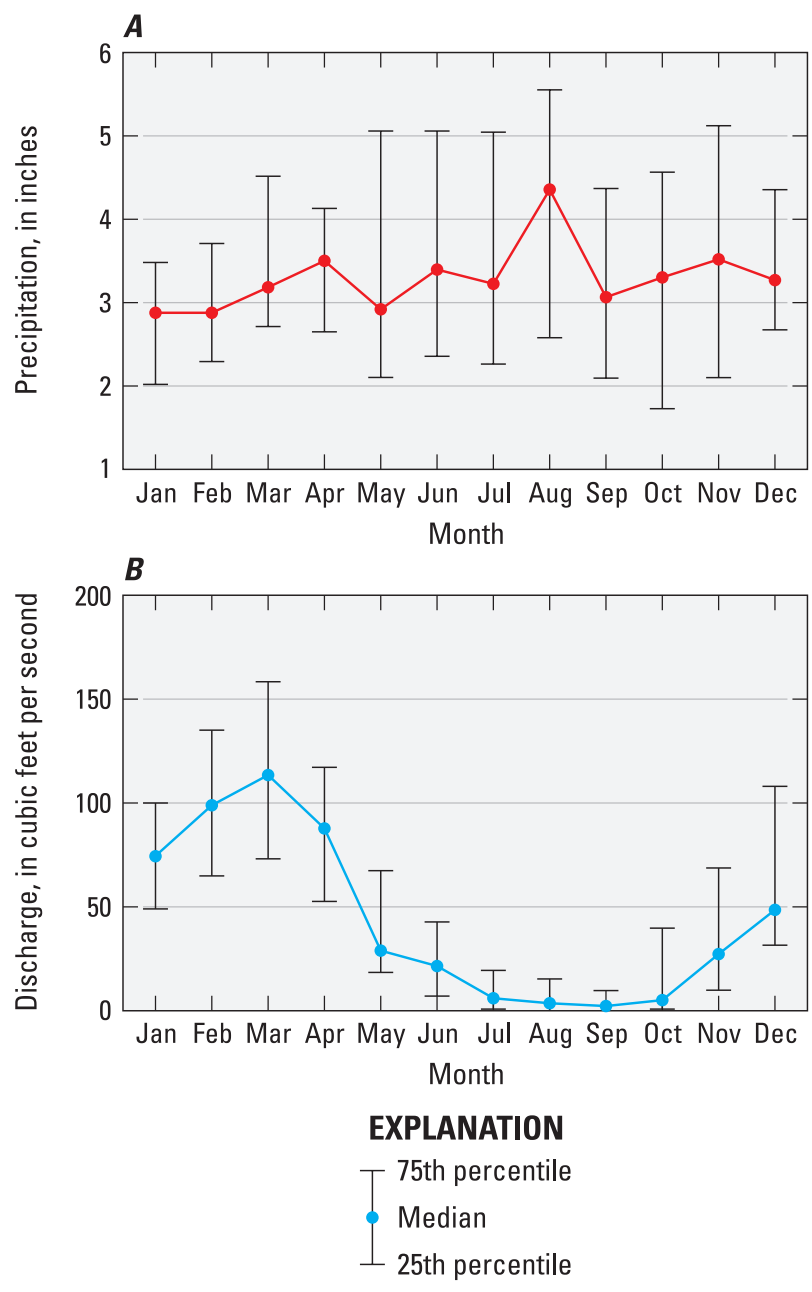

Figure 2. (A) median monthly precipitation for lower southern Maryland (Charles, St. Mary's, and Calvert Counties; National Climatic Data Center, 2002b), and (B) discharge at Mattawoman Creek for water years 1951-71 and 2002-10 (the water years for which complete monthly discharge data are available).

are over 1,000 failing septic systems in the MSSA (Charles County Department of Planning and Growth Management, 2006). Also, whereas County stormwater management practices are consistent with the 2007 Maryland Stormwater Management Act, wet-weather urban runoff was considered the predominant point source of nutrients in the 2005 Total Maximum Daily Load (TMDL) (Maryland Department of the Environment, 2004).

Aside from the pattern of urbanization, perhaps the most prominent land-cover feature in the watershed is the flood plain of Mattawoman Creek, classified almost entirely as woody wetland, and accounting for nearly all of that landcover classification (fig. 3). The bottomland hardwood forest on the flood plain has both Zone IV and V (drier) flood-plain plant communities (Wharton and others, 1982) dominated by Oak (Quercus spp), Swamp Maple (Acer rubrum) and Pawpaw (Asimina triloba), with a patchy herbaceous layer (Noe and Hupp, 2007). The flood plain is episodically inundated, with overbank flows in the vicinity of the streamgage initiating at a discharge of about $400 \mathrm{ft}^{3} / \mathrm{s}$ (Noe and Hupp, 2007); for water years $2001-10$, daily mean discharge exceeded this value an average of 11 days per year.

Mattawoman Creek in the vicinity of the gage (and for most of its length) flows in a low-gradient, sand-bottomed, intermittently braided channel, and is generally well-shaded, with abundant woody debris and occasional beaver dams. The gage is located on the downstream side of the Route 227 (Pomfret Road) bridge. The bridge is a concrete structure with two vertical mid-channel supports. Both are solid, perpendicular to the road centerline, and span the entire bridge width under the road; along with the abutments on each end of the bridge, this configuration creates three side-by-side box culverts of equal dimension (fig. 4). Two main-channel braids join in a small pool just above the bridge. Old Womans Run, a tributary with a drainage area of $5.8 \mathrm{mi}^{2}$ (see fig. 1), enters the river-left braid about 100 feet (ft) upstream of the pool. All instrumentation, including the staff gage, water-level sensor, auto-sampler intake, and multi-sensor sonde, are mounted to the concrete bridge abutment downstream of the bridge at leftedge water (LEW) (fig. 4).

\section{Description of Comparison Basins}

In order to evaluate the nutrient- and sediment-concentration data and load estimates for Mattawoman Creek, four other watersheds in Maryland that are all tributaries to the Chesapeake Bay and similar in size to Mattawoman Creek were identified for comparison. Selection of these watersheds was based on size, availability of a similar record of concentration and flow data supporting load estimates, and representativeness of a range of hydrogeomorphic and land-use settings (table 1). Samples for nutrients and suspended sediment were collected by USGS from Mattawoman Creek, the Northwest Branch Anacostia River, and the Choptank River, and by the Maryland Department of Natural Resources (MDDNR) from Georges Creek and the North Branch Patapsco River. In order to facilitate comparison of water quality in Mattawoman Creek with that of its downstream Bay tributary, the USGS station at the Potomac River at Chain Bridge was included in the comparison group. All of the sites listed in table 1 are currently sampled using a similar protocol, which minimally includes routine monthly sampling as well as at least eight storm samples per year. However, inter-agency differences in regulatory requirements and sampling design, as well as project-specific data needs, result in records that differ in subtle ways; for the comparison sites, the most significant differences are included in table 1. In 2006, MDDNR adjusted its sampling strategy in order to align itself with protocols applied throughout the Chesapeake Bay region. At the two MDDNR stations (North Branch Patapsco River and George's Creek), 


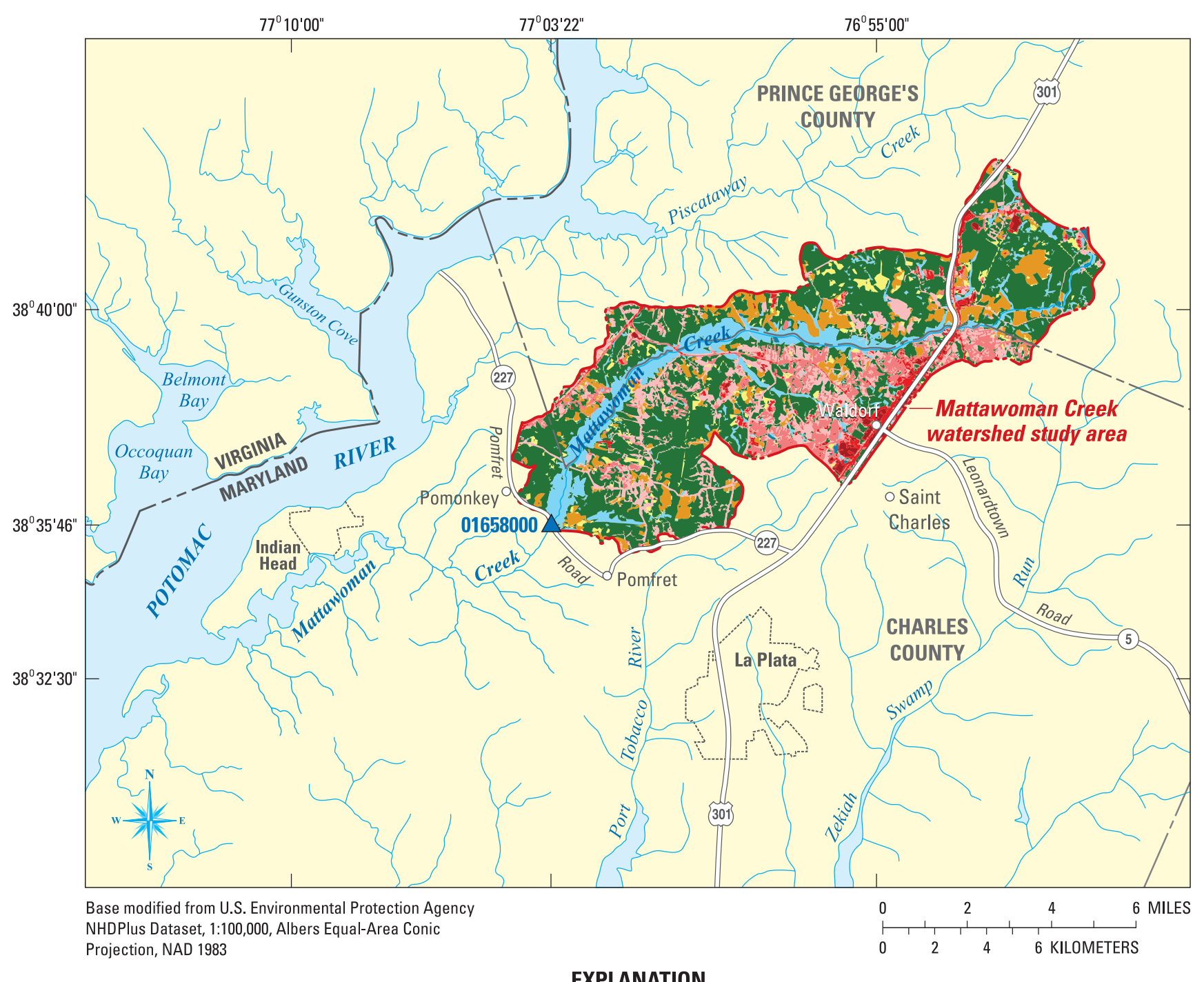

LAND COVER

\begin{tabular}{|l|l|}
\hline Other & Developed, high intensity \\
\hline Open water & Forest \\
\hline Developed, open space & Agriculture \\
\hline Developed, low intensity & Wetland \\
\hline Developed, medium intensity & \\
\hline
\end{tabular}

${ }^{01658000} \triangle$ U.S. Geological Survey streamgaging station and identifier

Figure 3. Land cover in the Mattawoman Creek watershed, 2006 (modified from Fry and others, 2011).

data collected prior to July 2005 consisted of fixed-interval monthly samples; storm sampling was added after July 2005. At that time, the sampling method was changed from edge-ofwater point samples to equal-width-increment (EWI) depthintegrated samples, consistent with USGS methods. Also at that time, the method for measuring water-borne sediment during storms and high monthly flows was changed from total suspended solids (TSS) to suspended-sediment concentration (SSC; W. Romano, MDDNR, oral commun., October 2012). The entire periods of record for both Mattawoman Creek and the Northwest Branch Anacostia River include a mixture of EWI samples collected manually and point samples drawn by an auto-sampler on the bank. All of these differences can influence site-to-site comparisons of concentration and load in ways that are both site- and constituent-specific, but which have not been researched in depth. Compilation of comparison data did not include an in-depth analysis of point sources; such sources are mentioned in the basin descriptions below only in cases where water-quality impacts associated with the source have been documented. 




Figure 4. Aerial orthophotograph of the gage location showing location of main channel braids and the mouth of Old Womans Run relative to the location of the gage, continuous water-quality sonde, and sampler intake, 2007 (source: U.S. Geological Survey National Geospatial Program). [Blue cross indicates location of the operational sonde and auto-sampler intake; red cross indicates location of the temporary sonde deployed in 2011; yellow dashed line indicates location where equal-width-increment (EWI) samples are collected; and black dashed lines indicate positions of flow-segregating bridge supports (underside of bridge)].

\section{Choptank River near Greensboro, Maryland, U.S. Geological Survey Station Number 01491000}

The streamgage at the Choptank River near Greensboro, Maryland (USGS station number 01491000), has been in operation since 1948 and intensive water-quality monitoring by the USGS River Input Monitoring (RIM) Program has been conducted since 1985. The Choptank River above Greensboro drains a $113-\mathrm{mi}^{2}$ watershed in the south-central region of the Delmarva Peninsula. The watershed is primarily agricultural and contributes less than 1 percent of the total freshwater input to the Chesapeake Bay estuary. The Choptank River Basin lies entirely within the Atlantic Coastal Plain and has relatively flat topography with unconsolidated sediments. Phillips and Bachman (1996) classified the watershed above the Choptank River station as "poorly drained," however Ator and others (2005) classified this area as well-drained sands with overlying gravels with strong agricultural land cover indicative of excellent drainage. Land cover in the Choptank River watershed is predominantly agricultural (49 percent; table 1), but there is also a significant amount of wetlands ( 23 percent), indicating the presence of some areas with poor drainage as described by Phillips and Bachman (1996). Poorly drained uplands on the Delmarva often yield lower concentrations of nitrogen than well-drained areas, because saturated soils support reducing conditions necessary for denitrification (Phillips and Bachman, 1996).

\section{North Branch Patapsco River at Cedarhurst, Maryland, U.S. Geological Survey Station Number 01586000}

The North Branch Patapsco River at Cedarhurst, Maryland (USGS station number 01586000) has a period of record for discharge from 1945 to the present. The watershed 
Table 1. Station location, size, and land cover for Mattawoman Creek, four similarly sized comparison basins, and the Potomac River.

[USGS, U.S. Geological Survey; $\mathrm{mi}^{2}$, square miles; EWI, equal-width increment; EW, edge water; SSC, suspended-sediment concentration; TSS, total suspended solids; point, samples collected by auto-sampler at EW]

\begin{tabular}{|c|c|c|c|c|c|c|c|c|c|c|}
\hline \multirow{2}{*}{ Station location } & \multirow{2}{*}{$\begin{array}{l}\text { USGS } \\
\text { station } \\
\text { number }\end{array}$} & \multirow{2}{*}{$\begin{array}{l}\text { Water- } \\
\text { shed } \\
\text { size } \\
\left(\mathrm{mi}^{2}\right)\end{array}$} & \multirow{2}{*}{$\begin{array}{l}\text { Physio- } \\
\text { graphic } \\
\text { province }\end{array}$} & \multicolumn{4}{|c|}{$\begin{array}{l}\text { Land cover } \\
\text { (percent) }\end{array}$} & \multirow{2}{*}{$\begin{array}{l}\text { Sampling } \\
\text { frequency }\end{array}$} & \multirow{2}{*}{$\begin{array}{l}\text { Sampling } \\
\text { method }\end{array}$} & \multirow{2}{*}{$\begin{array}{l}\text { Sedi- } \\
\text { ment } \\
\text { analysis }\end{array}$} \\
\hline & & & & Urban & Forest & Agriculture & Wetlands & & & \\
\hline $\begin{array}{l}\text { Mattawoman Creek } \\
\text { near Pomonkey, Md. }\end{array}$ & 01658000 & 54.8 & $\begin{array}{l}\text { Coastal } \\
\text { Plain }\end{array}$ & 28 & 47 & 9 & 12 & $\begin{array}{l}\text { Monthly } \\
+ \text { storms }\end{array}$ & $\begin{array}{c}\text { EWI + } \\
\text { point } \\
\text { (EW) }\end{array}$ & SSC \\
\hline $\begin{array}{l}\text { Northwest Branch } \\
\text { Anacostia River near } \\
\text { Hyattsville, Md. }\end{array}$ & 01651000 & 49.4 & $\begin{array}{l}\text { Piedmont, } \\
\text { Coastal } \\
\text { Plain }\end{array}$ & 68 & 22 & 7 & 2 & $\begin{array}{l}\text { Monthly } \\
+ \text { storms }\end{array}$ & $\begin{array}{c}\text { EWI + } \\
\text { point } \\
\text { (EW) }\end{array}$ & SSC \\
\hline $\begin{array}{l}\text { Choptank River near } \\
\text { Greensboro, Md. }\end{array}$ & 01491000 & 113 & $\begin{array}{l}\text { Coastal } \\
\text { Plain }\end{array}$ & 6 & 20 & 49 & 23 & $\begin{array}{l}\text { Monthly } \\
+ \text { storms }\end{array}$ & EWI & SSC \\
\hline $\begin{array}{l}\text { Georges Creek at } \\
\text { Franklin, Md. }\end{array}$ & 01599000 & 72.4 & $\begin{array}{c}\text { Appalachian } \\
\text { Plateau }\end{array}$ & 9 & 78 & 9 & 0 & $\begin{array}{l}\text { Monthly; } \\
\text { storms } \\
\text { added } \\
\text { beginning } \\
2005\end{array}$ & $\begin{array}{c}\text { Point } \\
\text { (EW); } \\
\text { EWI } \\
\text { beginning } \\
2005\end{array}$ & $\begin{array}{c}\text { TSS; } \\
\text { SSC } \\
\text { during } \\
\text { storms } \\
\text { begin- } \\
\text { ning } \\
2005\end{array}$ \\
\hline $\begin{array}{l}\text { North Branch Patap- } \\
\text { sco River at Cedar- } \\
\text { hurst, Md. }\end{array}$ & 01586000 & 56.8 & Piedmont & 17 & 27 & 52 & 0.4 & $\begin{array}{l}\text { Monthly; } \\
\text { storms } \\
\text { added } \\
\text { beginning } \\
2005\end{array}$ & $\begin{array}{c}\text { Point } \\
\text { (EW); } \\
\text { EWI } \\
\text { beginning } \\
2005\end{array}$ & $\begin{array}{c}\text { TSS; } \\
\text { SSC } \\
\text { during } \\
\text { storms } \\
\text { begin- } \\
\text { ning } \\
2005\end{array}$ \\
\hline $\begin{array}{l}\text { Potomac River at } \\
\text { Chain Bridge }\end{array}$ & 01646580 & 4,467 & $\begin{array}{l}\text { Valley and } \\
\text { Ridge, } \\
\text { Blue Ridge, } \\
\text { Piedmont }\end{array}$ & 9 & 54 & 27 & 0.4 & $\begin{array}{l}\text { Monthly } \\
+ \text { storms }\end{array}$ & EWI & SSC \\
\hline
\end{tabular}

${ }^{1}$ Fry and others (2011).

above the station is in the Piedmont Physiographic Province in northern Maryland. The geology in the area is fractured and deformed crystalline rock with relatively good drainage at the surface. The topography includes rolling hills with sometimes steep gorges and steep-sided river valleys. The watershed is primarily rural with a significant amount of row cropping and pasture.

\section{Georges Creek at Franklin, Maryland, U.S. Geological Survey Station Number 01599000}

Georges Creek at Franklin, Maryland (USGS station number 01599000) has operated as a streamflow monitoring station intermittently since 1905, and continuously from 1929 to the present. The watershed is in the Allegheny High Plateau
Region of the Appalachian Plateau Physiographic Province in western Maryland, with steep stratigraphy and topography, little or no flood plains, and high-energy, well-dissected streams. The watershed is predominantly forested, although acid mine drainage has had a significant impact, influencing both water quality and hydrology. The site is approximately 2.5 mi downstream from the Allegany County Treatment Plant (wastewater treatment) and is affected by combined sewer overflows (CSOs). Georges Creek was listed on Maryland's 303(d) list for overall impairment by biological oxygen demand (BOD) and nutrients, but was de-listed for nutrients subsequent to TMDL development (Maryland Department of the Environment, 2004). Water-quality samples have been collected by MDDNR under the same program and at the same sampling frequency as the North Branch Patapsco River station. 
Northwest Branch Anacostia River near Hyattsville, Maryland, U.S. Geological Survey Station Number 01651000

The Northwest Branch Anacostia River near Hyattsville, Maryland (USGS station number 01651000) is just above the highest point of tidal influence, which occurs near the confluence with the Northeast Branch Anacostia River at Bladensburg, Maryland. The watershed above the gaging station is highly developed, due to its close proximity to Washington, D.C. Urbanization is the most dominant influence on the Anacostia River; the highest percentage of land cover in the Northwest Branch watershed is urban with several industrial point-source discharges, but no municipal sewagetreatment plants. In the headwaters, there is some agricultural land cover (7 percent) including row and grain crops, pasture, orchards, and forested areas. The physiography of the watershed is transitional between the Atlantic Coastal Plain and the Piedmont Plateau with some steeper gradients through the Fall Line (the junction of these two provinces). The combination of relatively high gradients through the Fall Line and stream channelization from development makes this a very flashy stream with a lot of energy during storm events. There have been numerous stream-restoration projects, both upstream and downstream of the sampling station on the Northwest Branch, and they have potentially influenced the amount of sediment and nutrients that were transported (Miller and others, 2007).

\section{Potomac River at Chain Bridge, U.S. Geological Survey Station Number 01646580}

The Potomac River is the second largest tributary to the Chesapeake Bay, contributing approximately 20 percent of the total flow to the Bay. The Potomac River at Chain Bridge (USGS station number 01646580) has been monitored by the RIM Program since 1985 and was included as a major large-watershed station in the early 1990s for the Potomac River study unit of the USGS National Water-Quality Assessment (NAWQA) Program. This station is of interest to the Chesapeake Bay Program because it is the most downstream nontidal station for the Potomac River Basin, although it is upstream of most of the densely urban influences of Washington, D.C. For logistical reasons and for the purposes of calculating sediment and nutrient loadings, flow measurements are measured 1.2 mi upstream at the Potomac River near Washington, D.C. Little Falls Pumping Station (USGS station number 01646500). The Potomac River watershed above Chain Bridge is a transition of topography and geomorphology from the Appalachian Plateau in the headwaters, through the Valley and Ridge, and Piedmont Physiographic Provinces. The predominant land cover in the watershed is mixed but unevenly distributed across the basin, with primarily forested areas in the headwaters, dense agriculture in the mid- basin, particularly in the Great Valley region, and transitioning into densely populated urban areas in the east.
Major agriculture in the watershed includes crops such as corn and hay with some soybeans, and livestock (poultry, cattle, and sheep).

\section{Methods of Study}

Two types of water-quality and water-quantity data were collected at the sampling station on Mattawoman Creek: (1) 15-minute (hereinafter, "continuous") measurements were made for discharge, $\mathrm{pH}$, water temperature, specific conductance, concentration of dissolved oxygen, and turbidity; and (2) discrete water-quality samples were collected to determine the concentrations of nutrients and suspended sediment. Continuous discharge data were collected beginning in January 2001, turbidity data were collected beginning in October 2003, and all other continuous parameters were collected beginning in March 2003. Discrete samples were collected beginning in October 2000. All data were archived in the USGS National Water-Information System (NWIS) database and are available upon request from the USGS MarylandDelaware-D.C. Water Science Center (MD-DE-DC WSC) in Baltimore, Maryland.

Field methods described in this report are documented in the USGS National Field Manual for the Collection of Water-Quality Data (U.S. Geological Survey, variously dated) and Guidelines and Standard Procedures for ContinuousWater-Quality Monitors (Wagner and others, 2006). Chapters of the National Field Manual are updated on a continuous basis and are available online at http://water.usgs.gov/owq/ FieldManual/.

\section{Measurements of Continuous Flow and Water Quality}

The streamflow-gaging station at Mattawoman Creek was operated according to standard USGS streamgaging protocols (Rantz and others, 1982). Briefly, continuous discharge measurements were estimated from river stage and recorded using a pressure transducer. The gage height was recorded every 15 minutes, and a stage-discharge relation, constructed from individual measurements of discharge made throughout the range of stages over the course of the study, was applied to create a record of continuous discharge. Continuous-data collection for $\mathrm{pH}$, water temperature, specific conductance, concentration of dissolved oxygen, and turbidity was performed using a YSI multi-parameter sonde deployed at LEW (fig. 4). Over the course of the study, Models 6600 and 6980 V2 sondes were used. The sonde reported readings of each parameter collected at 15-minute intervals to a Campbell Scientific CR10X data logger, which stored the data for transmission via satellite to the USGS at 4-hour intervals. Specific conductance and $\mathrm{pH}$ data were temperature-compensated to 77 ${ }^{\circ} \mathrm{F}$ ( 25 degrees Celsius, or ${ }^{\circ} \mathrm{C}$ ). Continuous data were reported 
in near-real time online at $h t t p: / / w a t e r d a t a . u s g s . g o v / m d / n w i s /$ current/?type $=$ quality.

In order to ensure the accuracy and precision of the data, equipment was field-inspected and calibrated at intervals ranging from 1 to 4 weeks as dictated by hydrologic conditions, data quality (fouling and drift), and the known functional limitations of the equipment. For cleaning and calibration of the water-quality sensors, multiple observations of each parameter were made during the entire process, and were used to determine separate corrections for both fouling and drift. Standards for specific conductance and $\mathrm{pH}$ were quality-assured by their manufacturers (RICCA Chemical and Fisher Scientific Company, respectively), and include traceable lot numbers. Standards for turbidity were manufactured by GFS or YSI and were used without dilution. Shifts and corrections, calculated using criteria outlined in Wagner and others (2006), were applied to the continuous water-quality records in the USGS NWIS database after each field inspection was completed. Discharge and discrete and continuous (beginning in 2003) water-quality data were published in the USGS Annual Water Data Report for water years (October through September) 2001 to 2010.

\section{Field Collection of Discrete Water-Quality Samples}

Discrete water-quality samples were collected both manually and by an auto-sampler. Manual samples were collected about $30 \mathrm{ft}$ downstream from the gaging station during wadeable conditions using an isokinetic sampler and EWI sampling techniques (U.S. Geological Survey, variously dated). To collect a sample representative of stream conditions at the time of sample collection, multiple depth-integrated subsamples were collected at equal intervals across the stream (approximately 5 to 10 sections, depending on discharge at the time of sample collection) and composited into a pre-cleaned polyethylene churn splitter. Field data for water and air temperature, barometric pressure, $\mathrm{pH}$, specific conductance, concentration of dissolved oxygen, and turbidity were collected from the stream cross section using a handheld YSI field meter (Model 6600 or $6920 \mathrm{~V} 2$ ) at the time of each manual sampling event.

The water-quality samples were processed on site in the gage house, in a clean USGS field vehicle, or at the USGS MD-DE-DC WSC laboratory in Baltimore, to avoid environmental contamination. Subsamples of whole water were withdrawn from the churn splitter into clean polyethylene bottles while churning at a rate of 9 in. per second. After all whole-water samples had been withdrawn, samples for dissolved analysis were collected from the churn using a peristaltic pump with an in-line polycarbonate capsule filter (0.45-micrometer or $\mu \mathrm{m}$ effective pore size). Samples for whole-water analysis of nutrients were preserved with 1 milliliter $(\mathrm{mL})$ of sulfuric acid. Samples for nutrients were chilled to less than $39^{\circ} \mathrm{F}\left(4^{\circ} \mathrm{C}\right)$ and shipped on ice overnight to the
USGS National Water Quality Laboratory (NWQL) in Denver, Colorado. Samples for suspended sediment were stored and shipped later to the USGS Sediment Laboratory in Louisville, Kentucky.

An ISCO refrigerated auto-sampler was installed so that samples could be collected more frequently during storm events. Samples were collected through the sampler intake into 2.5-liter (L) polyethylene sampler bottles. Automatic sample collection during a storm event was initiated by a pre-determined rise in stream stage above a specified value and proceeded at timed intervals. Three to six discrete samples were collected over each storm hydrograph, based on changes in flow and precipitation. After each targeted storm event, USGS personnel reviewed the hydrograph and selected a subset of samples, typically three, that best represented the rise, peak, and recession of the storm hydrograph. These samples were then processed and analyzed in the manner described above for manually collected samples. To compare methods for EWI and autosampling, several samples were collected simultaneously using both techniques.

\section{Laboratory Methods}

Nutrients were analyzed at the NWQL in Denver, Colorado. Prior to water year 2006, samples for total and soluble phosphorus and Kjeldahl nitrogen were digested concurrently in block digestors at high temperature with a mercury, $\mathrm{Hg}(\mathrm{II})$, catalyst. Ammonium ions, including those that were originally present and those that were generated by the procedure, were analyzed colorimetrically by a salicylatehypochlorite Berthelot-reaction procedure using an airsegmented continuous-flow analyzer. Ammonia nitrogen was analyzed separately on a filtered sample by the same colorimetric procedure, and organic nitrogen was determined by difference; specific relations between measured water quality parameters and constituents computed by sum or difference are provided in Appendix A. Phosphate was analyzed in a separate aliquot from the same digestate using the ammoniummolybdate colorimetric method and automated segmented flow (Fishman, 1993; Patton and Truitt, 2000). Nitrite-nitrogen was analyzed by diazotization and colorimetric detection in automated segmented flow. Nitrate was reduced by cadmium metal and analyzed as nitrite to give total nitrate/nitrite-nitrogen (Fishman, 1993). Nitrate-nitrogen was then determined by difference. Total nitrogen was calculated as the sum of total Kjeldahl nitrogen and total (filtered) nitrate/nitrite-nitrogen. Beginning in October 2005, total nitrogen and phosphorus were determined using alkaline persulfate digestion (Patton and Kryskalla, 2003) in place of Kjeldahl digestion on both filtered and whole-water samples. For nitrogen, this technique measures both organic and inorganic species. Dissolved organic, dissolved inorganic, and particulate components were obtained by difference (Appendix A).

Suspended-sediment concentrations and the percent of sediment that was finer than $63 \mu \mathrm{m}$ were analyzed using 
filtration and gravimetric methods at the USGS Sediment Laboratory in Louisville, Kentucky. All methods and qualityassurance procedures for sediment analyses are documented in the laboratory quality-assurance plan (Shreve and Downs, 2005).

\section{Regression Models for Nutrients and Sediment}

The use of high-frequency in situ observations of parameters that are relatively easy to measure as surrogates for parameters that may be more ecologically relevant, but difficult to measure, is a well-established approach to estimating concentrations and loads, and for interpreting water quality in running waters (Christensen and others, 2000; Christensen, 2001; Rasmussen and Ziegler, 2003; Rasmussen and others, 2005; Jastram and others, 2009). For this study, linear regression relations were determined to estimate suspended sediment, total phosphorus, and total nitrogen at Mattawoman Creek using continuous sonde observations. Model development approaches followed the general procedures described for multiple linear regression in Helsel and Hirsch (1992). The first step in this analysis was to plot chemical concentrations against in-stream sensor measurements in order to visually identify potential relations, explore candidate transformations to linearize relations, and initially screen for potentially problematic observations. Models were then selected using the stepwise procedure as implemented in the SPlus Statistical Package, version 8.1 (TIBCO Corporation, 2008). This procedure iteratively adds and removes candidate predictors from the model, using Akaike's Information Criterion (AIC) (Helsel and Hirsch, 1992) as a measure of the degree of improvement or degradation associated with adding or dropping terms. The "best" model selected on the basis of the AIC balances two opposing objectives: maximizing explanatory power and minimizing the number of predictors used. Models selected with this process were diagnostically screened for adherence to standard assumptions of linear regression, and to assess the degree to which the selection of predictors may have been based on one or a few influential observations. Models identified as robust were further evaluated for susceptibility to bias associated with any required back-transformation to linear space, and a bias-mitigating correction (the "smearing correction"; Duan, 1983; Helsel and Hirsch, 1992) was computed and applied.

\section{Estimates of Loads and Yields}

The USGS RIM Program is an ongoing effort to quantify loads and long-term trends in concentrations of nutrients and suspended material entering the tidal part of the Chesapeake Bay Basin from nine major tributaries. Computations for RIM load and trend estimates are performed by fitting a sevenparameter regression model to estimate log-transformed constituent concentration, using an intercept and terms representing log-transformed daily discharge, log-transformed daily discharge squared, time, time squared, and two sinusoidal terms representing season-of-year (Langland and others, 2006). Regression coefficients are estimated using the Adjusted Maximum Likelihood Estimator (AMLE), which substantially reduces bias in parameter estimates when the data contain censored observations (Cohn, 1988; Cohn and others, 1992; Cohn, 2005). To minimize the effects of multicollinearity, discharge and time terms are represented relative to their mean value (they are "centered"; Langland and others, 2006). Daily loads are then calculated as the product of estimated concentration and observed daily discharge, and summed to compute a total load, with associated confidence bounds, over any period of interest (for example, a water year). These estimates can also be normalized to basin area, to determine "yields" for each basin that are independent of the size of the watershed.

Subsequent to its initial application as the basis for Bay loading estimates, the seven-parameter regression model was published by the USGS as the FORTRAN program LOADEST (Runkel and others, 2004); LOADEST has recently been packaged for either interactive or scripted use as an S-Plus add-on (Lorenz and others, 2011). LOADEST offers considerable additional flexibility, including the ability to include predictor variables other than flow, and to compute estimates based on hourly rather than daily data.

By virtue of the length of its discharge and water-quality record, as well as the sampling protocol that targets both low flows and storm hydrographs, Mattawoman Creek is included in a group of about 40 smaller watersheds in the Chesapeake Bay Program's Nontidal Network (NTN; Chesapeake Bay Program, 2004), for which USGS estimates downstream loads and yields using the same seven-parameter model used for the nine RIM sites. The gaged part of Mattawoman Creek is less than half the size of the smallest of the nine RIM watersheds (Choptank River; gaged area is $113 \mathrm{mi}^{2}$ ), and the proportion of total loading to the Bay that originates in the watershed is correspondingly small. However, estimates computed using this modeling framework still provide a credible indication of loading from the upland part of the Mattawoman Creek watershed to the Mattawoman estuary itself. Thus, the results are ecologically relevant at the local scale.

In this component of the study, annual loading estimates for suspended sediment, total phosphorus, and total nitrogen for water years 2002-10 were computed using the LOADEST implementation of the seven-parameter model, and compared to estimates for the same period published by the NTN Program, to confirm the comparability of the models.

LOADEST was then used to assess the effect of applying the seven-parameter models for these constituents at an hourly, as opposed to daily, time step. Finally, the potential benefit of including continuously measured parameters as additional predictor terms in the model, as suggested by the regression models developed for nutrients and sediment, was explored. 


\section{Evaluation of Data Integrity}

Quality-control measures for this study included (1) field maintenance of the continuous water-quality sondes and subsequent application of corrections for fouling and drift (discussed earlier); (2) analysis and interpretation of 78 discrete quality-assurance and quality-control (QA-QC) water-quality samples, (3) QA checks on selected constituents computed from water-quality parameters by difference, and (4) temporary deployment of an additional continuous sonde to assess the potential effects of incomplete lateral mixing, associated with the location of the sampling equipment downstream of the mouth of Old Womans Run.

\section{Discrete-Sample Quality Assurance}

QC discrete samples included blanks and replicates. Blanks provide an indication of the concentrations of target water-quality parameter(s) present in the environmental sample that could be attributed to field procedures, sample handling, or analytical methods. Of the 19 blanks processed during the study period, analysis of 15 of them resulted in concentrations below the laboratory reporting limit for all parameters considered; this indicates that the influence of collection, processing, and laboratory procedures on reported environmental concentrations is generally negligible. Analysis of a blank collected on October 20, 2009 indicated a suspendedsediment concentration of 12 milligrams per liter $(\mathrm{mg} / \mathrm{L})$, well above the reporting limit of $1 \mathrm{mg} / \mathrm{L}$ and greater than the 25th percentile of concentrations observed for environmental samples. Analysis of a blank collected on December 19, 2006 resulted in a suspended-sediment concentration of $4 \mathrm{mg} / \mathrm{L}$, near the 10th percentile of concentrations observed in environmental samples, and had detectable filtered total nitrogen. Results for a blank collected on December 12, 2007 indicated a concentration of ammonia of $0.04 \mathrm{mg} / \mathrm{L}$, twice the reporting limit and greater than the median of observed environmental concentrations. Finally, analysis of a blank collected on March 27,2008 resulted in a concentration of filtered total nitrogen of $0.28 \mathrm{mg} / \mathrm{L}$, above the reporting limit of $0.1 \mathrm{mg} / \mathrm{L}$ but less than the 10th percentile of observed environmental concentrations. All four of these blanks were auto-sampler blanks; they were obtained by drawing pure water through the normally submerged end of the auto-sampler intake, using the same pre-collection flushing procedure used for environmental sampling. The source of the contamination may have been inadequate flushing, or material dislodged from the interior of the submerged part of the sampler intake. However, the unusual manipulation required to artificially expose the intake to obtain the blank is itself a potential source of contamination. Of the 19 blanks analyzed over the course of this study, 9 were autosampler blanks, and laboratory results for 5 of these indicated concentrations below the reporting limits for all parameters. For the first three of the four problematic blanks discussed above, affected parameters (suspended sediment, suspended sediment and filtered total nitrogen, and ammonia, respectively) associated with environmental samples collected on the same day were excluded from further analysis. The sampler tubing was changed immediately after the blank was collected on March 27, 2008, and analysis of a second blank collected immediately thereafter indicated that all concentrations were below reporting limits; thus, the corresponding environmental sample, collected through the new tubing, was retained.

Replicates provide an indication of variability in the environmental process being sampled, or of variability introduced at a particular stage of sample collection, processing, and analysis. For the purposes of discussion, replicates are grouped herein as persulfate, cross-section, or other procedural/environmental. Persulfate replicates are split samples, one of which was analyzed for nutrients using Kjeldahl digestion (used in this study through water year 2005) and the other using alkaline persulfate digestion (beginning in water year 2006). A total of nine such replicates were collected and analyzed, all during water year 2005. Only the first, collected on December 28, 2004, indicated a notable discrepancy between the two methods. Both filtered and unfiltered total nitrogen determined by the persulfate method for that sample were lower than values determined by the corresponding Kjeldahl method (Kjeldahl plus nitrate plus nitrite) by a factor of roughly 2.5 . No explanation was evident from examination of field and laboratory notes/remarks.

Cross-section replicates in this study consist of paired observations, one of which was drawn by the auto-sampler at LEW, and the other collected simultaneously as an EWI cross-section composite. Comparison of analytical results for the two samples provides an indication of the degree to which samples drawn at LEW are representative of the entire stream cross section. The 10 cross-section replicates collected and analyzed over the course of the study indicate the potential for incomplete lateral mixing under low-flow conditions. Considering missing observations for some parameters, the 10 cross sections yielded 88 possible pair-wise comparisons of parameter values. Of these, 79 comparisons, or roughly 90 percent, showed absolute differences in parameter values less than the 10th percentile of that parameter's observed concentration in all environmental samples. In three cases, absolute differences in parameter values exceeded the 25 th percentile of the parameter's observed range. In a comparison of samples collected on September 5, 2001 under low-flow conditions, the concentration of suspended sediment observed at LEW was $14 \mathrm{mg} / \mathrm{L}$ higher than the concentration observed in the cross section composite (19 mg/L compared to $5 \mathrm{mg} / \mathrm{L}$, a difference of 280 percent). In another low-flow comparison performed on July 19, 2005, suspended-sediment concentration observed at LEW was higher than the cross section composite value by $34 \mathrm{mg} / \mathrm{L}$ (43 mg/L compared to $9 \mathrm{mg} / \mathrm{L}$, a relative difference of 380 percent). In the same pair of samples, Kjeldahl nitrogen observed at LEW was $0.3 \mathrm{mg} / \mathrm{L}$ less than that observed in the composite $(0.5 \mathrm{mg} / \mathrm{L}$ compared to $0.8 \mathrm{mg} / \mathrm{L}$, a relative 
difference of about 40 percent). The two samples with noteworthy discrepancies were collected under two of the three lowest flow conditions encountered over the 10 visits at which cross-section comparisons were made. This indicates that there is potential for incomplete lateral mixing downstream of the mouth of Old Womans Run, at least under steady low-flow conditions (fig. 4).

Other procedural/environmental replicates included pairs collected either concurrently from different samplers or sequentially from the same sampler at exactly the same location, or a single sample that is split at some point subsequent to sampling, and then subjected to identical handling and laboratory analysis. Depending on the specific intent of the replication method, differences in analytical results for this set of replicates may reflect sample-to-sample variability in the environment, or variability introduced through sample handling, processing, and analysis. The 18 such replicates collected and analyzed over the course of the study generally indicated that the sampling protocol accurately and precisely represented environmental conditions. Of all of the water-quality parameters considered, 86 percent of all possible pair-wise differences in concentration between these replicates were below the laboratory reporting limit for the parameter under consideration. Because of differences in the intent of specific replicates, and because water-quality parameters varied widely in their range of environmental concentrations, exceptions were considered on a case-by-case basis. Generally, exceptions deemed "practically significant" differed in absolute magnitude by more than the 10th percentile of the given parameter's observed concentration in environmental samples and differed in relative magnitude by more than 20 percent. For suspended sediment, differences of this type were observed in the analysis of a split replicate derived from the auto-sampler collected on the rising limb of a storm hydrograph on January 20, 2001. Analysis of another auto-sampler split replicate collected near a large storm peak on April 14, 2002 showed practically significant differences in unfiltered Kjeldahl nitrogen, probably resulting from the presence of entrained particulate organic matter in one of the subsamples. Analysis of a split replicate derived from an EWI cross-sectional sample collected at low flow on June 1, 2005 revealed differences in both filtered ammonia and filtered nitrite, indicating spurious contamination during or after the splitting procedure. Finally, analysis of a sequential replicate obtained by manually re-triggering the auto-sampler immediately after a programmed sample on the falling limb of a large storm hydrograph on April 18, 2007 resulted in practically significant differences in both orthophosphate and suspended sediment. Only these 6 pair-wise discrepancies were present in 18 procedural/environmental replicates, each analyzed for 8-12 water-quality parameters. These results indicate that (1) variability associated with sample collection and handling is generally small compared to environmental variability, and (2) environmental sampling is repeatable and precise.

\section{Constituents Computed by Difference}

In this study, particulate organic nitrogen was computed using the difference between unfiltered and filtered Kjeldahl nitrogen prior to water year 2006, and using the corresponding difference in values obtained by the persulfate method beginning in water year 2006 (Appendix A). Of 346 samples for which particulate organic nitrogen was computed, 64 results were less than zero, a physically unrealistic outcome. Of the 64, 6 were computed using the Kjeldahl method, and 58 were computed using the persulfate method. The median particulate nitrogen concentration considering all observations was 0.10 $\mathrm{mg} / \mathrm{L}$, with the distribution of the persulfate values shifted to the left (negatively) relative to the Kjeldahl values by 0.07 $\mathrm{mg} / \mathrm{L}$ (median values $0.06 \mathrm{mg} / \mathrm{L}$ and $0.13 \mathrm{mg} / \mathrm{L}$, respectively, $\mathrm{n}=167$ and 179; Wilcoxon rank sum $\mathrm{p}$ is less than 0.0001). For context, the smallest total (particulate plus dissolved organic plus dissolved inorganic) nitrogen concentration observed in environmental samples $(\mathrm{n}=346)$ was $0.22 \mathrm{mg} / \mathrm{L}$.

In 2009, the USGS Office of Water Quality documented several instances of suspected under-estimation of unfiltered total nitrogen using the persulfate method. Subsequent investigation revealed that in some cases, the method can fail to digest and detect an environmentally relevant proportion of particulate nitrogen; the degree of underestimation was found to be related to suspended-sediment concentration, but the nature of the relation was site-specific (U.S. Geological Survey, 2009). The marked increase in negative values for computed particulate nitrogen at Mattawoman after the persulfate method was adopted in water year 2006 indicate that this analytical problem likely introduced a bias in the Mattawoman particulate nitrogen data. Analysis of particulate nitrogen in this study was limited to reporting median monthly concentrations, relative to other nitrogen species. Since particulate nitrogen was the smallest component of total nitrogen in this study (median overall value of $0.10 \mathrm{mg} / \mathrm{L}$, compared to $0.35 \mathrm{mg} / \mathrm{L}$ and $0.26 \mathrm{mg} / \mathrm{L}$ for dissolved organic and inorganic nitrogen, respectively), no adjustment was attempted. The anomaly does indicate that total nitrogen after 2005 was slightly underestimated, which could influence conclusions regarding trends in loading. Beginning in September 2011, the differencing computation of particulate nitrogen using persulfate digestion at Mattawoman was replaced with a combustion method, as recommended by USGS RIM Program staff (J.D. Blomquist, U.S. Geological Survey, written commun., August 2011).

\section{Lateral Mixing}

As discussed in the Description of Mattawoman Creek and Watershed section, inflow from Old Womans Run enters Mattawoman Creek on river left just upstream of the Route 227 bridge. The sampling instrumentation is located just downstream of the bridge, also on river left (fig. 4). This geometry suggests a potential for lateral (cross-channel) 
gradients in water quality resulting from inflow from Old Womans Run, particularly in light of the flow-segregating box-culvert style construction of the bridge. Some degree of bias, at least under low steady-flow conditions, was evident in the analysis of the cross-section replicates discussed earlier. In addition, the rising limbs of storm hydrographs at Mattawoman frequently contain features indicative of a short-lived inflow that precedes the main hydrograph peak (fig. 5). These features range from a subtle "shoulder," evident as an inflection point in the slope of the rising limb, to a distinct "double-peak" effect; when evident as distinct peaks, the features persist for time spans of approximately 6 hours. The delay between the transient inflows inferred from these features and the main hydrograph peak can range from less than 12 hours to longer than a day. One possible explanation is that these features are associated with the left braid of the Mattawoman main stem, inactive under low-flow conditions such as those shown in figure 4, becoming active as main-stem flow increases. However, it seems unlikely that simple initiation of flow in the left channel braid would induce features as prominent and persistent as the most evident cases shown in figure 5. The features are more consistent with a transient inflow from a smaller, relatively flashy nearby tributary superimposed on a delayed, more rounded flood wave from a larger watershed. Whereas flow from Old Womans Run has not been directly measured, the physical configuration of the channel system upstream of the sampling location indicates that tributary as the probable source (fig. 4). If this hypothesized explanation is accurate, the existence of a second, nearby upstream source on the same side of the creek as the sampling equipment could induce time-varying lateral gradients in water quality; this in turn could complicate the interpretation of discrete samples or sonde readings collected by the instrumentation deployed at LEW.

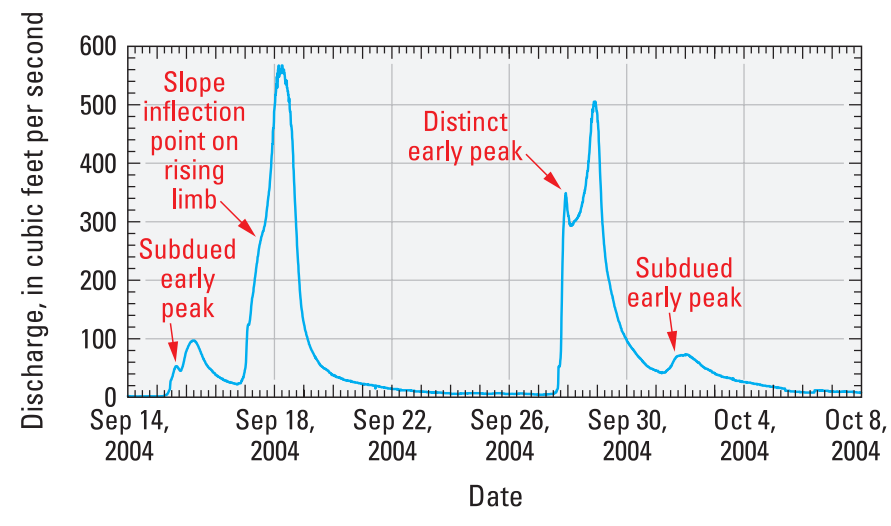

Figure 5. Example storm hydrographs for a 3-week period in 2004 at Mattawoman Creek showing varying degrees of influence of inflow from Old Womans Run on the shape of the hydrograph rising limb.
In order to investigate the potential for cross-sectional gradients in water quality under dynamic conditions at this site, a second continuous water-quality sonde was temporarily deployed from the bridge from March through June 2011. The sonde was suspended in the water column from the center of the box culvert on river right; essentially, it sampled river water striking the bridge from the river-right channel braid, opposite the permanent sonde (fig. 4). Both sondes were programmed to sample simultaneously, and the temporary sonde was subject to the same level of field maintenance and data QA-QC as the operational sonde at LEW. Both sondes revealed highly dynamic behavior during storms, with maximum changes in continuous parameters at LEW observed just before the inflection points evident on the rising limb of the discharge hydrograph, and maximum changes at the temporary sonde observed later, just prior to peak flow (fig. 6). Frequently, large changes observed at LEW were simultaneously evident in subdued form at the temporary sonde, and large changes observed at the temporary sonde were evident in subdued form at LEW; this is particularly evident in the turbidity time series in figure 6 . The pattern is consistent with the conceptual model of two time-varying flow sources, each with its own time-varying chemistry, mixing incompletely above the bridge. Downstream flow on river left then has a water-quality signature biased towards the presumed input from Old Womans Run, whereas water quality on river right is biased towards the larger Mattawoman watershed. The dualsonde data thus provide a more complete characterization of the situation indicated, at least under low steady-flow conditions, by the cross-section replicates discussed previously in the Discrete-Sample Quality Assurance section.

This situation highlights some of the challenges associated with sampling a braided channel with multiple tributaries entering along its length (fig. 1). Lateral water-quality gradients associated with tributary inflows can persist downstream, in extreme cases, for miles (for example, Sommer and others, 2008). Because of the time-varying nature of the lateral gradients observed at the Route 227 bridge, quantitative interpretation of the magnitude and timing of runoff components or pollution sources based on data gathered at LEW on the time scale of individual storms may be inaccurate (fig. 6); trends and patterns evident at longer time scales, such as months or seasons, may be more robust. Regardless of time scale, all data must be interpreted as representative of some amalgam of water-quality conditions both in Old Womans Run and Mattawoman Creek; the data do not distinguish the waterquality effects of land-use change in the greater Mattawoman watershed from the effects of land-use change in the Old Womans Run watershed. Of the 360 discrete water-quality samples collected, 100 were collected as EWI cross sections, and the remainder were collected by the auto-sampler at LEW. Consequently, regression analyses investigating the utility of continuous surrogates for discretely measured parameters such as sediment and nutrients, in which all discrete samples are paired with corresponding continuous parameters measured by the sonde at LEW, may show more unexplained variability 


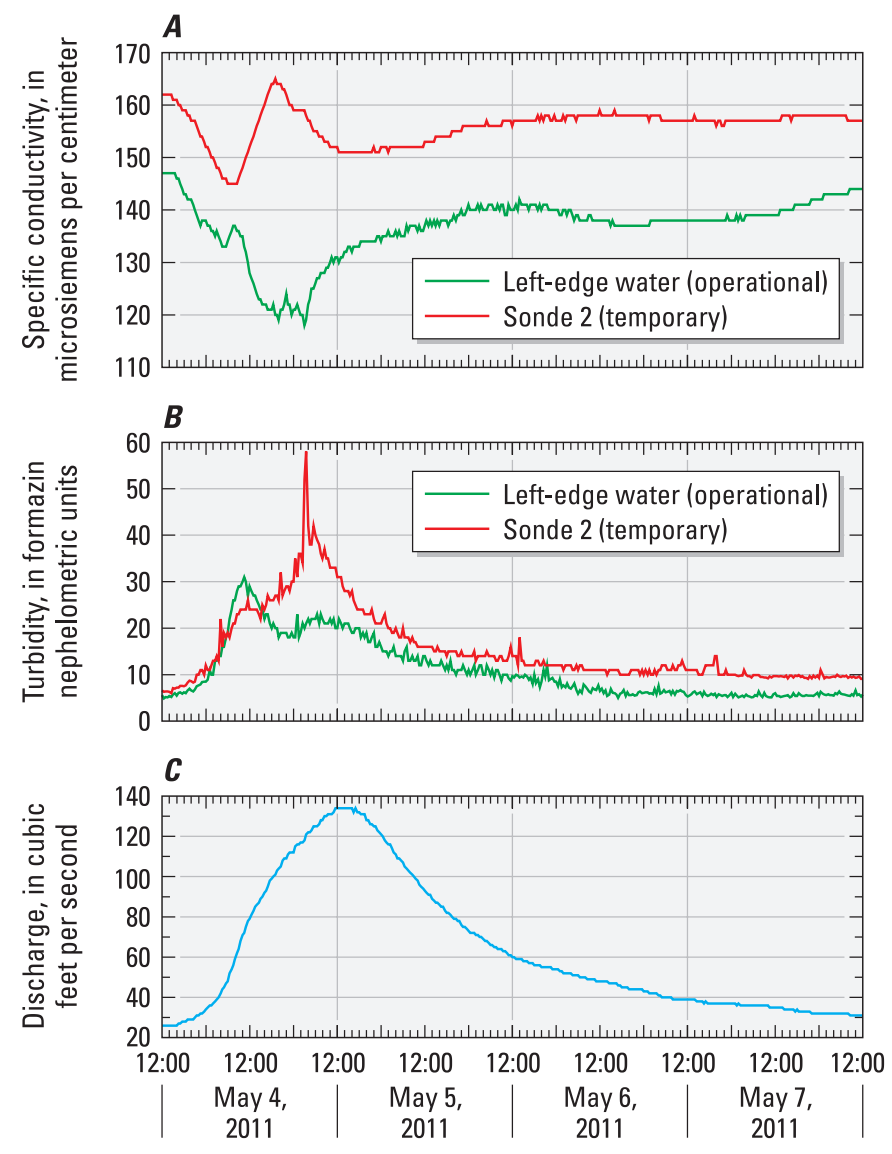

Figure 6. Examples of concurrent 15-minute data collected by the operational water-quality sonde at left-edge water (presumed to be influenced by Old Womans Run) and the temporary sonde (Sonde 2) deployed in 2011 in the center of the rightmost bridge culvert (presumed to be primarily representative of the Mattawoman Creek main channel) (A) specific conductance, $(B)$ turbidity, and (C) discharge.

than would be anticipated under well-mixed conditions. Finally, the full record of simultaneous sonde observations indicates that water sampled at LEW, presumably more influenced by inflow from Old Womans Run, is consistently more dilute and episodically more turbid than presumed main-stem flow (fig. 7). To the extent that these differences are representative of differences over the entire study period, loading estimates, which integrate the product of concentration and flow, will be biased towards the presumed inflow from Old Womans Run. The results that are interpreted in this report take into account all possible influences on the data; limitations associated with incomplete lateral mixing are discussed in more detail in the following sections, in association with results to which they are particularly relevant.

\section{Hydrologic Conditions}

Mean annual precipitation for water years 2002 (the first year of this study period for which complete discharge data were available) through 2010 was typical for lower southern Maryland (46.0 in., compared to the 1971-2000 regional normal of 44.8 in.; National Climatic Data Center, 2002b; fig. 8a). However, this period included both an extremely dry year and an extremely wet year: only 26.20 in. in 2002 followed by $66.66 \mathrm{in}$. in 2003; below the 5 th and above the 95th percentiles, respectively, for the period 1971-2000. These extremes were reflected in the record of annual discharge for the study period, with the minimum mean annual flow of only $9.4 \mathrm{ft}^{3} / \mathrm{s}$ in 2002, followed by a maximum of $118 \mathrm{ft}^{3} / \mathrm{s}$, greater than the previous year by an order of magnitude, in 2003 (fig. $8 b$ ). The mean discharge for the nine water years during the study period was $68 \mathrm{ft}^{3} / \mathrm{s}$, higher than the overall mean of 58 $\mathrm{ft}^{3} / \mathrm{s}$ for the 31 years $(1951-72,2002-10)$ for which complete data were available for Mattawoman Creek. The mean annual runoff ratio (the proportion of annual rainfall that is discharged as streamflow) for the study period was 0.35 ; however, this was also highly variable, ranging from less than 10 percent to over one-half ( 0.09 in 2002 compared to 0.52 in 2007; data not shown).

Grouped by month, flows at Mattawoman Creek show a seasonal pattern typical of the humid temperate regional climate, with highest median continuous flow of $51 \mathrm{ft}^{3} / \mathrm{s}$ in February and minimum of $0 \mathrm{ft}^{3} / \mathrm{s}$ in September (fig. 9a). Median continuous flows during winter and spring are consistent, differing by only $10 \mathrm{ft}^{3} / \mathrm{s}$ between the months of December and April; similarly, median flows during the low-flow months of July, August, and September differ by only about $3 \mathrm{ft}^{3} / \mathrm{s}$. Overbank flows in the vicinity of the Mattawoman Creek gage, estimated by Noe and Hupp (2007) to start at approximately $400 \mathrm{ft}^{3} / \mathrm{s}$, follow a slightly different pattern, occurring most frequently in the months of December and March (16 and 15 days, respectively, over the study period) and relatively rarely between the months of July and October (fig. 8c). Days with no measureable flow during summer and early fall are common: over the study period, daily flow was zero or too low to measure for 14.7 percent of the continuous record, most frequently in August and September (fig. 8d). Altogether, there were 26 no-flow episodes ranging in length from 1 to 72 days.

The apparent susceptibility of the watershed to year-toyear variability in meteorological conditions, as evidenced by variability both in annual runoff and runoff ratio, together with the frequency and duration of no-flow periods, may indicate a limited capacity for water storage and (or) transmission. Ator and others (2005) noted that the surficial sediments of Inner Coastal Plain sands and gravels are typically completely dissected, with little hydrologic connectivity between upland deposits on adjacent hills. Alternately, the patterns may be indicative of the effects of groundwater withdrawal. Charles County reported withdrawals of roughly $12 \mathrm{Mgal} / \mathrm{d}$ in 2005 , with a major focus in the Waldorf area (Charles County 

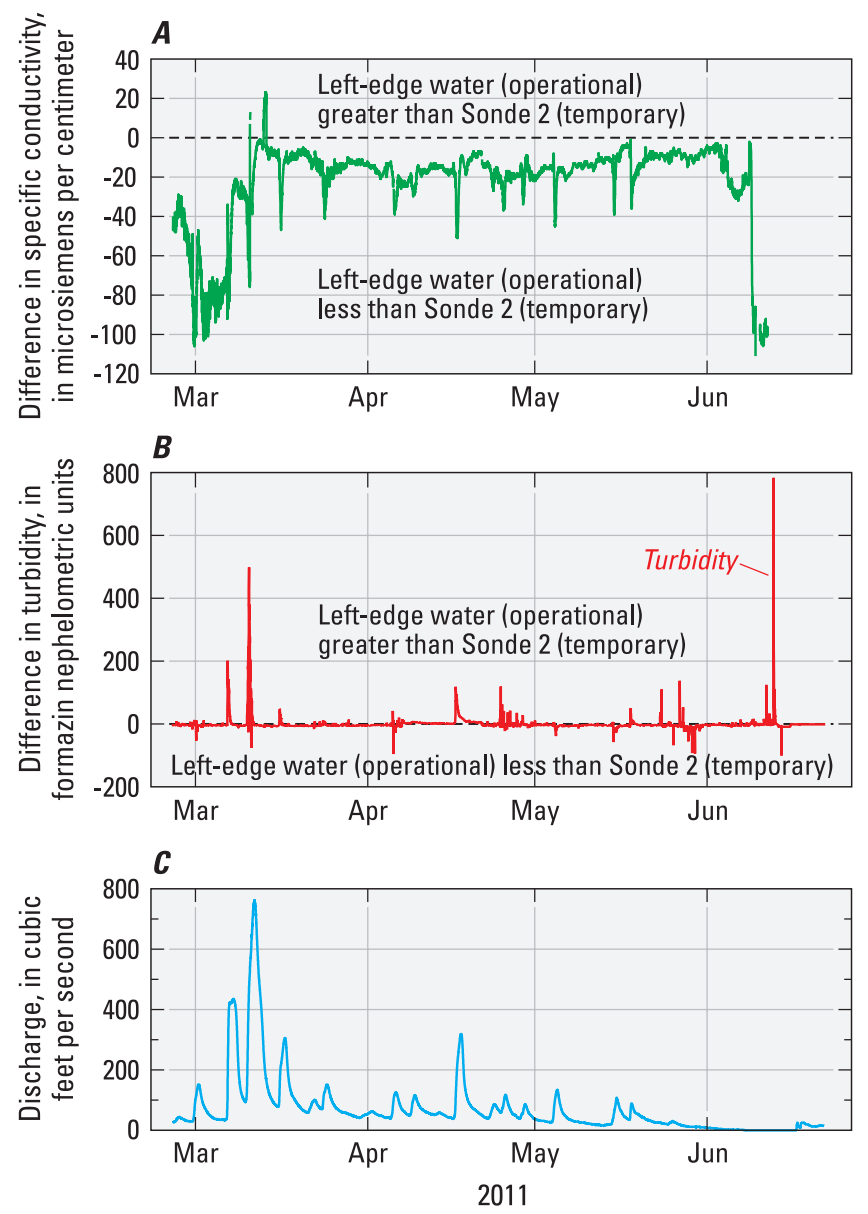

Figure 7. Difference in specific conductance and turbidity between the operational sonde mounted at left-edge water (presumed to be influenced by Old Womans Run) and the temporary sonde (Sonde 2) deployed in 2011 in the center of the rightmost bridge culvert (presumed to be primarily representative of the Mattawoman Creek main channel). (A) specific conductance, $(B)$ turbidity, and (C) discharge.

Department of Planning and Growth Management, 2006). This amount corresponds to approximately $18 \mathrm{ft}^{3} / \mathrm{s}$ if withdrawn directly from the creek. However, the dissected surficial sediments of the watershed are separated from the deeper regional water-supply aquifers by low-permeability units, collectively 150-300 ft thick in the Waldorf area, including the Calvert Formation, Nanjemoy Formation, and Marlboro Clay (Wilson and Fleck, 1990). The latter formation, a dense, silty clay, 15 to $30 \mathrm{ft}$ thick in the Waldorf area but widespread and readily identifiable throughout southern Maryland, has particularly low vertical hydraulic conductivity $\left(10^{-7}\right.$ to $10^{-6}$ feet per day or ft/d; Wilson and Fleck, 1990). Thus, although a more targeted investigation would be required to conclusively rule out the influence of groundwater withdrawal on streamflow at Mattawoman Creek, this explanation seems unlikely.

\section{Continuous Water-Quality Data}

Collection of continuous water-quality data for all parameters except turbidity began in March 2003; the turbidity sensor was deployed in October of that year. Data reported herein cover the period from those start dates through January, 2011 - nearly 8 years for most parameters and slightly more than 7 for turbidity.

Continuous turbidity observations were highly skewed: whereas the majority of observations ranged from about 1 to 100 Formazin Nephelometric Units (FNU) (fig. 9b), the overall range covered roughly four orders of magnitude, with minima on the order of $0.1 \mathrm{FNU}$ and maxima near 1,000 FNU. Median monthly values were relatively constant throughout the year, on the order of 4-5 FNU; both median and 95th 

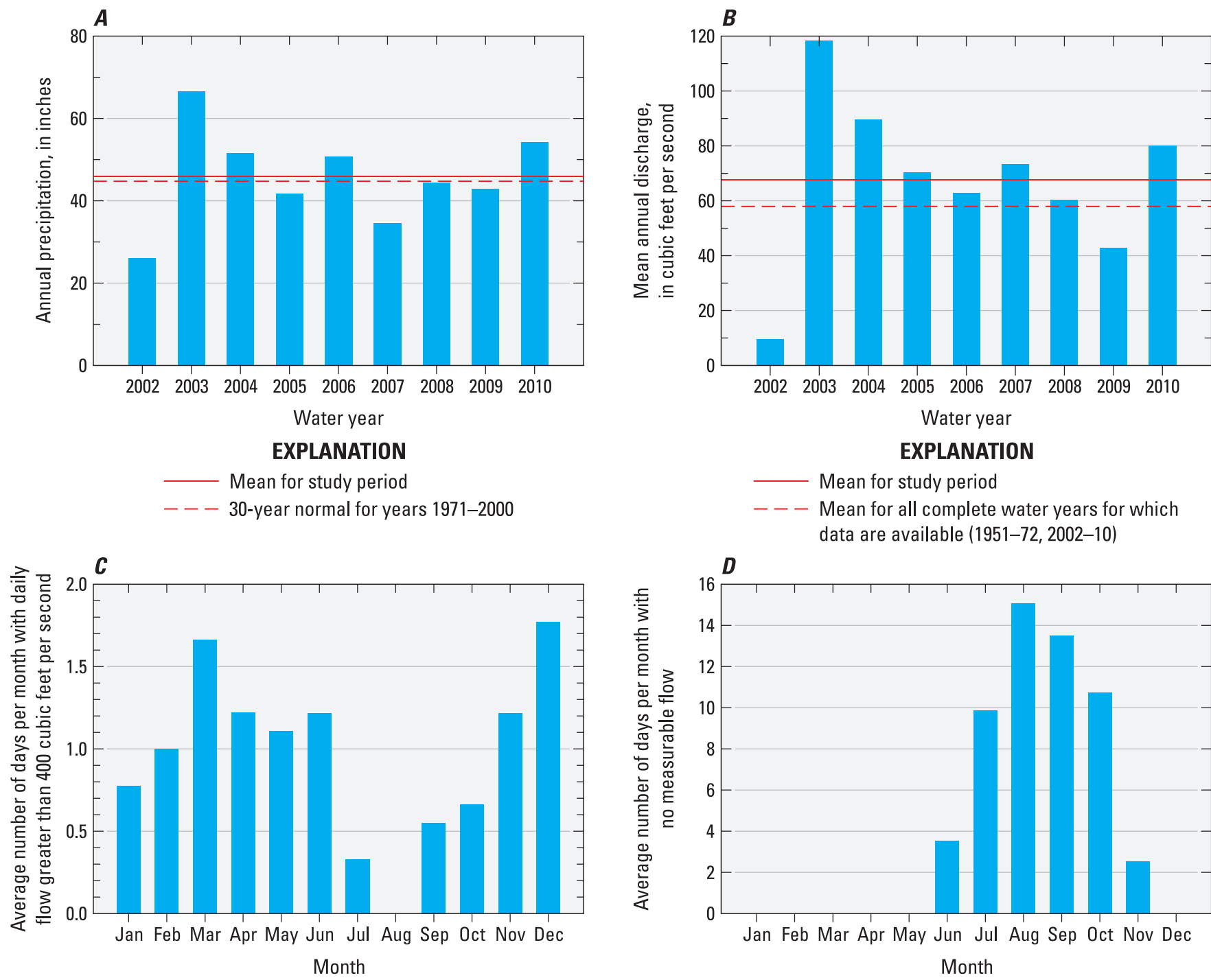

Figure 8. Hydrologic conditions at Mattawoman Creek, water years 2002-10 (A) Annual precipitation for southern Maryland (National Climatic Data Center, 2002b), $(B)$ mean annual discharge, $(C)$ monthly distribution of days with flow greater than 400 cubic feet per second (overbank at gage), and $(D)$ monthly distribution of days with no measureable flow.

percentile values were slightly elevated between April and July, with medians of 7.3 and 8.3 FNU in May and June, respectively. The coincidence of the highest median turbidity values in late spring, after the high-median-flow months of December through April, indicates the influence of an additional source of particulates during those months, in addition to increased transport capacity relative to low-flow conditions (figs. 9a, b).

Seasonal patterns in water temperature corresponded to those in air temperature, with the lowest monthly median water temperature $\left(32^{\circ} \mathrm{F}\right)$ in January and highest $\left(70.3^{\circ} \mathrm{F}\right)$ in July (fig. 9c). Seasonal variability in median dissolved oxygen concentrations showed a very similar, but inverted pattern (fig. 9d). Median values for all months were within about $1 \mathrm{mg} / \mathrm{L}$ of the theoretical solubility of oxygen at the corresponding median monthly temperature (data not shown). The annual pattern, with nearly saturated conditions year round, indicates that the creek is not subject to any significant external source of seasonal oxygen demand, such as the demand that might be associated with organic waste input (Wilhelm, 2009; Allen, 1995).

Month-to-month variation in median $\mathrm{pH}$ was only 0.2 units, with medians of 6.6 or 6.7 for all but 1 month (fig. 9e). The slight peak in median value of 6.8 in May probably reflects increased photosynthetic $\mathrm{CO}_{2}$ consumption by instream autotrophs, whose activity would be expected to peak as the stream warms in the spring, but prior to full leaf-out.

Monthly variability in continuous specific conductance observations is shown in figure 9f. A common conceptual framework for interpreting stream-water conductivity 

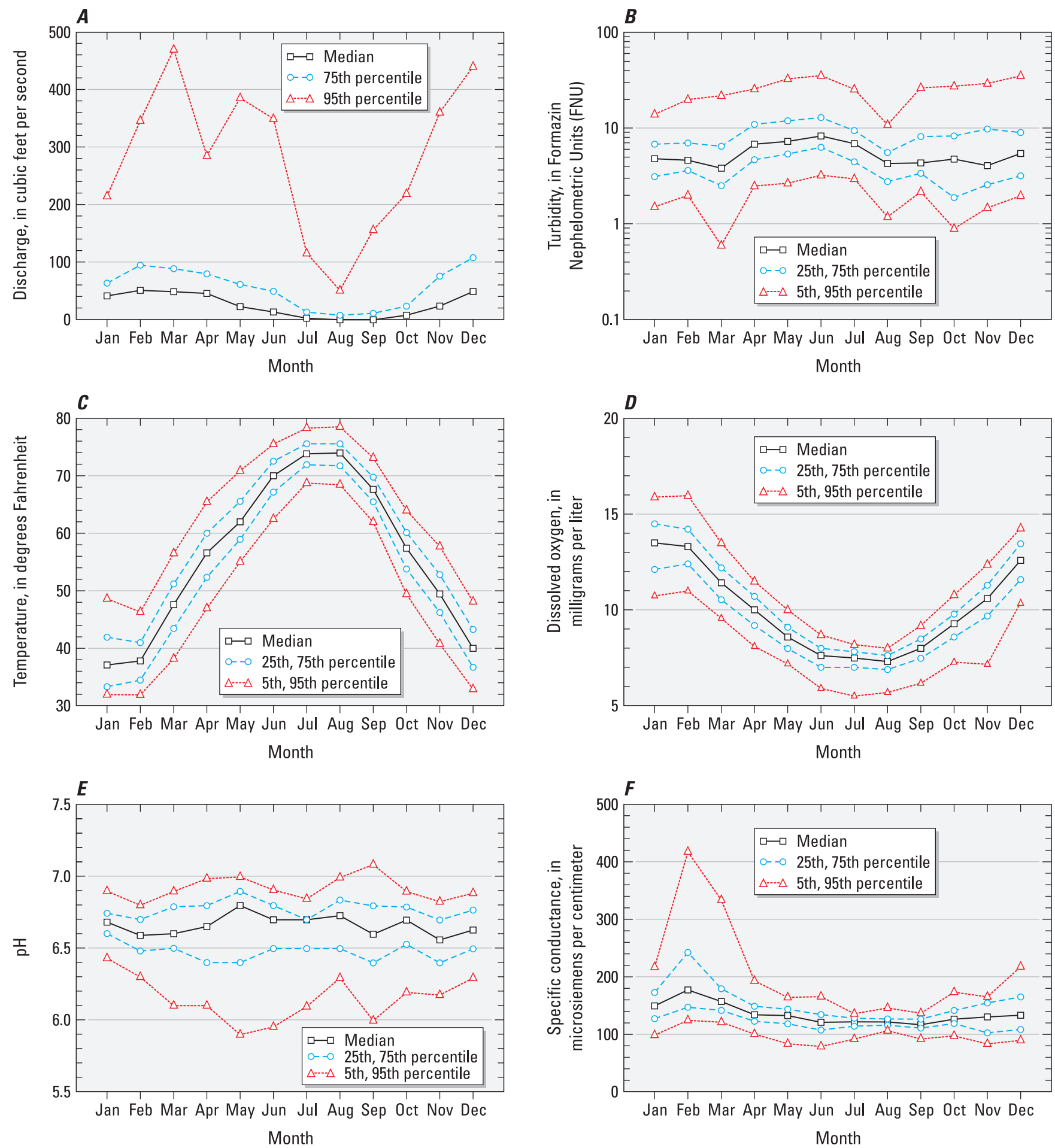

Figure 9. Monthly variation in 15-minute observations collected by the continuous water-quality sonde, Mattawoman Creek, 2003-10 (A) discharge, (B) turbidity, (C) temperature, (D) dissolved oxygen, (E) pH, and (F) specific conductance. 
considers streamflow to be a mixture of water from overland and shallow subsurface flow paths, with groundwater originating from deeper flow paths. The former is considered dilute in terms of ionic strength, and the latter more concentrated, by virtue of having had extended contact with watershed minerals (Matsubayashi and others, 1993). This concept is consistent with the pattern of episodic reduction in specific conductance associated with storms, followed by recovery as discharge decreases to pre-storm levels. This is evident, despite ambiguity associated with incomplete lateral mixing, in the trace for the LEW sonde in figure 6a. Assuming that streamflow in the lowest-flow months is sustained primarily by groundwater, this conceptual model predicts highest conductance values during the summer months. However, the opposite pattern is evident in the Mattawoman data (fig 9f). Moreover, the prevalence of high outliers in winter months indicates episodic enrichment. This pattern is consistent with the application of salt and other de-icing agents to roads and other impervious surfaces. Herlihy and others (1998) examined stream chemistry data relative to watershed land use in a probabilistic survey of 368 wadeable streams in the Mid-Atlantic region, including streams on the Atlantic Coastal Plain. They concluded that concentration of the chloride ion, primarily from road salt but also from other human-influenced sources, was the single best overall indicator of human disturbance throughout the region. In large quantities, de-icing agents have been implicated in raising surface-water salinity regionally to levels that threaten both aquatic life and suitability for human consumption (Kaushal and others, 2005). Median values of specific conductance at Mattawoman were highest in February (177 microsiemens per centimeter or $\mu \mathrm{S} / \mathrm{cm}$ ) and decreased to the lowest values in late summer $(122,122$, and $117 \mu \mathrm{S} / \mathrm{cm}$ in July, August, and September, respectively; fig. 9f). Ninetyfifth percentiles were also highest in February and lowest in July (418 and $136 \mu \mathrm{S} / \mathrm{cm}$, respectively). Although this pattern is a clear indication of human influence on water quality at Mattawoman, it is most appropriately considered in context: for the same period in the heavily urbanized Northeast Branch of the Anacostia River watershed near Washington, D.C. (USGS station number 01649500 , area $72.8 \mathrm{mi}^{2}$ ), median values of continuous specific conductance observations in February and July were 686 and $298 \mu \mathrm{S} / \mathrm{cm}$, respectively. The corresponding 95 th percentiles were 3,800 and $390 \mu \mathrm{S} / \mathrm{cm}$ (data not shown). Ongoing continuous monitoring of specific conductance, coupled with analysis of trends in monthly statistics, may be the best-available sentinel of the effects of increasing urbanization on water quality at Mattawoman Creek.

\section{Discrete Water-Quality Samples}

A total of 360 discrete water-quality samples were analyzed between October 24, 2000 and January 10, 2011. Of these, 260 were storm samples collected by the auto-sampler and 100 were cross-section integrated samples collected manually.

\section{Corresponding Range of Continuous Conditions}

The ranges of continuous parameter values corresponding to the times of discrete sample collection, relative to each continuous parameter's overall cumulative frequency distribution, are summarized in figure 10. Consistent with the sampling program design, sampling took place across a wide range of discharge values, with sampling occurring at instantaneous values from a minimum of $0.1 \mathrm{ft}^{3} / \mathrm{s}$ to a maximum of 2,920 $\mathrm{ft}^{3} / \mathrm{s}$. The median value of discharge at the time of sample collection was $127 \mathrm{ft}^{3} / \mathrm{s}$, somewhat higher than the median of all continuous discharge observations over the study period, which was $26 \mathrm{ft}^{3} / \mathrm{s}$ (fig. 10a). Samples were collected at turbidity values ranging from 1 to $450 \mathrm{FNU}$, with a median of 16 FNU (fig. 10b). For both discharge and turbidity, the range of the continuous parameter corresponding to times of discrete EWI cross-section sampling was somewhat lower than the range corresponding to times at which discrete automatic (LEW) samples were collected; this reflects the relative difficulty of collecting cross-section samples at high water. Water temperature at times corresponding to discrete sampling ranged from 32.0 to $76.3^{\circ} \mathrm{F}$, with a median value of $51.3^{\circ} \mathrm{F}$ (fig. 10c). Dissolved oxygen values associated with discrete samples ranged from 5.5 to $15.8 \mathrm{mg} / \mathrm{L}$, with a median of 10.3 $\mathrm{mg} / \mathrm{L}$ (fig. 10d). For both parameters, the range represented by EWI samples, from less than the 10th percentile to greater than the 90th percentile of the parameters' overall distribution, was similar to the range represented by auto-sampling. Median $\mathrm{pH}$ associated with discrete samples was 6.4, with a minimum of 5.6 and a maximum of 7.2 (fig. 10e). Specific conductance values corresponding to discrete sampling times ranged from 43 to $478 \mu \mathrm{S} / \mathrm{cm}$, with a median of $112 \mu \mathrm{S} / \mathrm{cm}$ (fig. 10f). Comparison of the relative ranges of $\mathrm{pH}$ and specific conductance represented by cross-section samples with the ranges represented by auto-sampling revealed a pattern opposite the one shown for discharge and turbidity: samples collected by the auto-sampler tended to represent lower ranges of $\mathrm{pH}$ and specific conductance than samples collected by cross section. Both $\mathrm{pH}$ and specific conductance were negatively correlated with discharge (see section on Interrelations between Physical Parameters, Nutrients, and Suspended Sediment), so the observed bias was another result of the tendency of auto-sampling to represent a higher range of discharge values.

\section{Suspended-Sediment and Nutrient Concentrations}

Suspended-sediment concentrations ranged over three orders of magnitude, with minimum and maximum values of 1 and nearly $3,000 \mathrm{mg} / \mathrm{L}(2,890 \mathrm{mg} / \mathrm{L}$; table 2$)$. The median of all observations was $24 \mathrm{mg} / \mathrm{L}$. The distribution of 



Specific conductance, in microsiemens per centimeter

\section{EXPLANATION}

Cumulative frequency Auto-sampler (left-edge water) samples $(n=259)$

Cross-section composite samples $(n=100)$

Figure 10. Cumulative frequency distributions of 15-minute discharge and water-quality sonde data, showing median parameter values (dots) and parameter ranges (whiskers) corresponding to collection of discrete water-quality samples $(A)$ discharge, $(B)$ turbidity, $(C)$ temperature, $(D)$ dissolved oxygen, $(E) \mathrm{pH}$, and $(F)$ specific conductance. 
Table 2. Constituent summary statistics for discrete water-quality samples collected at Mattawoman Creek, October 2000 through January 2011.

[The complete dataset is available online at http://waterdata.usgs.gov/nwis; $\mathrm{mg} / \mathrm{L}$, milligrams per liter; $\mu \mathrm{m}$, micrometers; LTMDL, long-term method detection limit; MRL, method reporting level (MRLs routinely change over time); values separated by slash ("/") indicate the minimum and maximum MRL applied over the course of this study; <, less than; --, not available]

\begin{tabular}{|c|c|c|c|c|c|c|c|}
\hline \multirow{3}{*}{ Constituent } & $\begin{array}{c}\text { Nitrate } \\
\text { (mg/L as N) }\end{array}$ & $\begin{array}{c}\text { Nitrite } \\
\text { (mg/L as } N \text { ) }\end{array}$ & $\begin{array}{c}\text { Ammonia } \\
\text { (mg/L as N) }\end{array}$ & $\begin{array}{c}\text { Total inorganic } \\
\text { nitrogen } \\
\text { (mg/L as } \mathrm{N} \text { ) }\end{array}$ & $\begin{array}{l}\text { Dissolved or- } \\
\text { ganic nitrogen } \\
\text { (mg/L as } \mathrm{N})\end{array}$ & $\begin{array}{l}\text { Particulate or- } \\
\text { ganic nitrogen } \\
\text { (mg/L as } \mathrm{N} \text { ) }\end{array}$ & $\begin{array}{c}\text { Total organic } \\
\text { nitrogen } \\
\text { (mg/L as } \mathrm{N})\end{array}$ \\
\hline & \multicolumn{7}{|c|}{ Source $^{1}$} \\
\hline & computed & analyzed & analyzed & computed & computed $^{2}$ & computed $^{2}$ & computed $^{2}$ \\
\hline LTMDL & -- & $0.001 / 0.003$ & $0.001 / 0.02$ & -- & -- & -- & -- \\
\hline \multirow[t]{3}{*}{ MRL } & -- & $0.001 / 0.006$ & $0.002 / 0.04$ & -- & -- & -- & -- \\
\hline & \multicolumn{7}{|c|}{ Number of observations } \\
\hline & 353 & 353 & 353 & 353 & 353 & 346 & 346 \\
\hline Minimum & 0.01 & $<0.001$ & $<0.015$ & 0.01 & 0.06 & $-1.19^{3}$ & 0.12 \\
\hline 25 th percentile & 0.14 & 0.002 & $<0.015$ & 0.15 & 0.26 & 0.03 & 0.33 \\
\hline Median & 0.23 & 0.002 & 0.020 & 0.26 & 0.35 & 0.10 & 0.44 \\
\hline
\end{tabular}

\begin{tabular}{|c|c|c|c|c|c|c|c|}
\hline \multirow[t]{3}{*}{ Constituent } & $\begin{array}{c}\text { Total nitrogen } \\
\text { (mg/L as N) }\end{array}$ & $\begin{array}{l}\text { Dissolved } \\
\text { inorganic } \\
\text { phosphorus } \\
\text { (mg/L as } \mathrm{P} \text { ) }\end{array}$ & $\begin{array}{c}\text { Particulate } \\
\text { phosphorus } \\
\text { (mg/L as P) }\end{array}$ & $\begin{array}{c}\text { Dissolved } \\
\text { organic phos- } \\
\text { phorus } \\
\text { (mg/L as } \mathrm{P})\end{array}$ & $\begin{array}{c}\text { Total } \\
\text { phosphorus } \\
\text { (mg/L as P) }\end{array}$ & $\begin{array}{c}\text { Suspended } \\
\text { sediment } \\
(\mathrm{mg} / \mathrm{L})\end{array}$ & $\begin{array}{l}\text { Fraction of } \\
\text { sediment less } \\
\text { than } 63 \mu \mathrm{m} \\
\text { (percent) }\end{array}$ \\
\hline & \multicolumn{7}{|c|}{ Source ${ }^{1}$} \\
\hline & computed $^{2}$ & analyzed & computed & computed & analyzed & analyzed & analyzed \\
\hline LTMDL & -- & $0.003 / 0.01$ & -- & -- & 0.004 & -- & -- \\
\hline \multirow{2}{*}{ MRL } & \multicolumn{7}{|c|}{ Number of observations } \\
\hline & 346 & 353 & 346 & 353 & 347 & 341 & 120 \\
\hline Minimum & 0.22 & $<0.003$ & 0.005 & $-0.021^{4}$ & 0.010 & 1 & 4 \\
\hline 25 th percentile & 0.56 & 0.006 & 0.026 & 0.007 & 0.045 & 9 & 44 \\
\hline
\end{tabular}

${ }^{1}$ Entries marked "analyzed" are parameters determined by laboratory analysis; entries marked "computed" are computed from more than one laboratory result; refer to text and Appendix 1 for specific formulae.

${ }^{2}$ Determination of dissolved and particulate nitrogen concentrations was done using Kjeldahl digestion prior to October 2005, and alkaline persulfate digestion afterwards. Differences in interpretation of analytical results require that different formulae be applied to calculate the indicated constituent; refer to text and Appendix 1 for specific formulae.

${ }^{3}$ Particulate fraction is calculated as the difference between unfiltered and filtered samples. Concentrations of the filtered sample exceeded concentrations of the unfiltered sample for a total of 66 observations; see text section "Evaluation of Data Integrity." Tabulated statistics include all observations.

${ }^{4}$ Dissolved organic fraction is calculated as the difference between total dissolved and dissolved inorganic fraction. Concentrations of the dissolved inorganic sample exceeded concentrations of the total dissolved sample for one observation. 
concentrations was highly skewed, with 75 percent of the observations falling below $69 \mathrm{mg} / \mathrm{L}$. The weight fraction of total suspended-sediment particles below 63 microns in diameter provides an indication of the proportion of the total concentration that appears as silt-size and finer, rather than sand-size particles. Reporting for this parameter was constrained to samples that had sufficient overall concentrations to confidently determine this fraction; in general, this result was not available for samples with total concentrations below about $50 \mathrm{mg} / \mathrm{L}$. Values for the 120 observations where this parameter was determined were fairly uniformly distributed, ranging from 4 to 95 percent, with a median of 63 percent (table 2).

Total phosphorus concentrations ranged from 0.010 to $0.980 \mathrm{mg} / \mathrm{L}$, with a median value of $0.070 \mathrm{mg} / \mathrm{L}$ (table 2). The median concentration for dissolved inorganic phosphorus (ortho-phosphorus), $0.009 \mathrm{mg} / \mathrm{L}$, was slightly over one-tenth the median for total phosphorus; the minimum observation was less than $0.003 \mathrm{mg} / \mathrm{L}$, and all but one observation were below $0.04 \mathrm{mg} / \mathrm{L}$. The distribution of dissolved organic phosphorus was very similar to that for dissolved inorganic phosphorus, with median and maximum values of 0.011 and 0.039 $\mathrm{mg} / \mathrm{L}$. Particulate phosphorus, computed as the difference between unfiltered total phosphorus and filtered total phosphorus, ranged from 0.005 to $0.952 \mathrm{mg} / \mathrm{L}$, with a median value of $0.047 \mathrm{mg} / \mathrm{L}$. Considering only median concentrations to characterize a "typical" sample, about 70 percent of total phosphorus was in particulate form, with the remaining 30 percent split approximately equally between dissolved inorganic and dissolved organic species.

The median observation for total nitrogen was $0.68 \mathrm{mg} / \mathrm{L}$; concentrations ranged from 0.22 to $4.09 \mathrm{mg} / \mathrm{L}$. The distribution of total nitrogen and all nitrogen species was positively skewed (table 2). Median values for the dissolved inorganic species nitrate, ammonia, and nitrite were $0.23,0.02$, and 0.002 , respectively; this reflects decreasing dominance in the concentration of the latter two constituents, relative to nitrate, by roughly one and two orders of magnitude, respectively. The median observation of total inorganic nitrogen, the sum of nitrate, ammonia, and nitrite, was $0.26 \mathrm{mg} / \mathrm{L}$; total inorganic nitrogen ranged from 0.01 to $0.90 \mathrm{mg} / \mathrm{L}$. Dissolved and particulate organic nitrogen were computed as the difference between filtered and unfiltered total nitrogen, respectively, and total inorganic nitrogen; the median values for these species were $0.35 \mathrm{mg} / \mathrm{L}$ and $0.10 \mathrm{mg} / \mathrm{L}$, respectively. When considering only aggregated median concentrations, about half of total nitrogen is typically in dissolved organic form, 35 percent is dissolved inorganic, and the remaining 15 percent is particulate. As discussed earlier in the Evaluation of Data Integrity section, the figure of $0.10 \mathrm{mg} / \mathrm{L}$ for particulate nitrogen is likely a modest underestimate. However, assuming there was no large shift in true environmental concentrations after the persulfate method was adopted in 2005, no correction for bias associated with the persulfate method would influence the ranking of species concentrations.

\section{Seasonal Patterns}

As discussed in the Methods section, discrete sampling was biased by design to collect samples from flows that were representative of the full range of discharge conditions encountered at Mattawoman Creek. Partly as a result of this design, monthly patterns in the distribution of continuous discharge measurements made at times corresponding to discrete sample collection (fig. 11) only slightly resembled corresponding patterns in the continuous discharge record (fig. 9a). The data show a dip towards low flows beginning in June, very low flows in August, and a recovery ending in October; beyond that feature, there was little other evidence of any seasonal pattern. Monthly patterns in suspended-sediment concentration corresponded somewhat to the pattern in discharge, but with evidence of a more consistently increasing trend between the months of February and June (fig. 12). A similar trend during these months was evident in the record of continuous turbidity (fig. 9b). The pattern of increasing median suspendedsediment concentration throughout the spring, in the absence of a parallel trend in discharge (a proxy for transport capacity) implies an increase in supply. Potential natural sources include material delivered from the flood plain associated with increased out-of-bank flows beginning in March (fig. 8c), or simply within-channel or channel-bank material mobilized by higher flows not exceeding bankfull. Alternately, the pattern could reflect sediment from increased warm-weather construction activity, conveyed by wet-weather urban runoff.

Seasonal patterns in total phosphorus and total nitrogen concentrations were similar in overall shape to each other, and to the seasonal pattern in suspended-sediment concentration, with phosphorus showing the most sharply resolved seasonal pattern of all (figs. 13, 14). The strength of these patterns and their similarity to the pattern for sediment is noteworthy in several respects. Foremost is the implication of one or more common watershed-scale mechanisms, natural or otherwise, that eclipse both sampling bias and any uncertainty in representativeness associated with location of the sampling equipment relative to the mouth of Old Womans Run. Second, unlike suspended sediment, water-column concentrations of nutrients are determined not only by supply and transport capacity, but also by terrestrial and aquatic biological activity, which influences both total concentrations and the relative sizes of the nutrient species' pools (Allen, 1995). The similarity in the seasonal pattern of concentrations of biologically inert (suspended sediment) and reactive (total nitrogen and phosphorus) constituents therefore implies either that physical controls dominate biological influences on total nutrient concentration, or that biological influences occur in seasonal synchrony with physical controls. Third, the simplest manifestation of a dominant physical control would have both nitrogen and phosphorus in predominantly particulate form; it would then be plausible that their concentrations could be influenced by the same physical processes that mobilize sediment. However, particulate nitrogen is the smallest component of total nitrogen; the largest component is the dissolved 


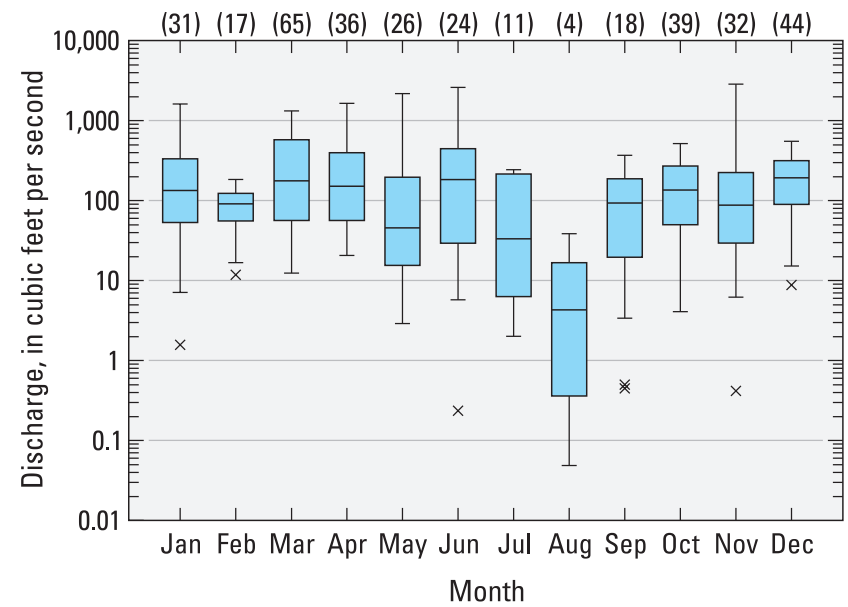

Figure 11. Monthly variation in continuous discharge observations at times corresponding to collection of discrete water-quality samples, Mattawoman Creek, 2001-10.

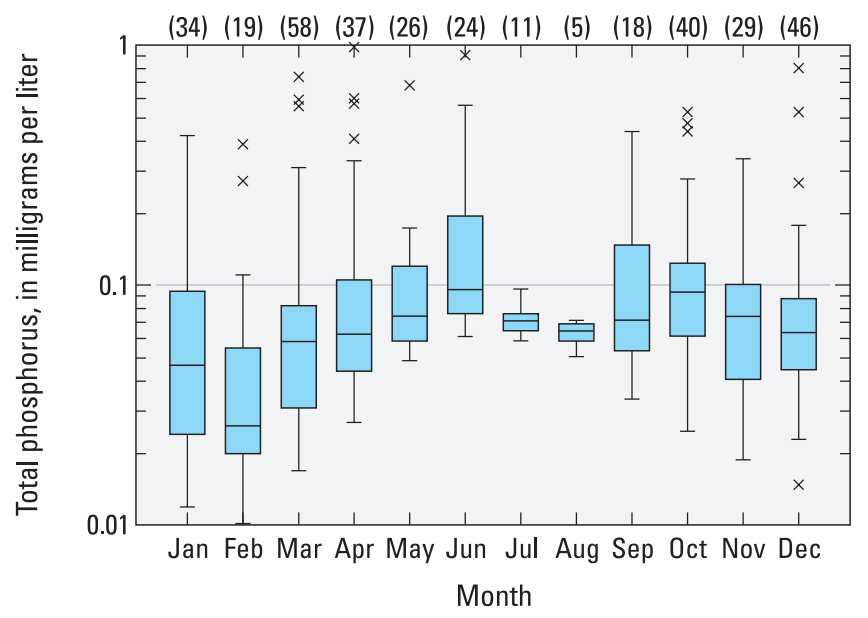

Figure 13. Monthly variation in total phosphorus concentrations, discrete water-quality samples, Mattawoman Creek, 2001-10.

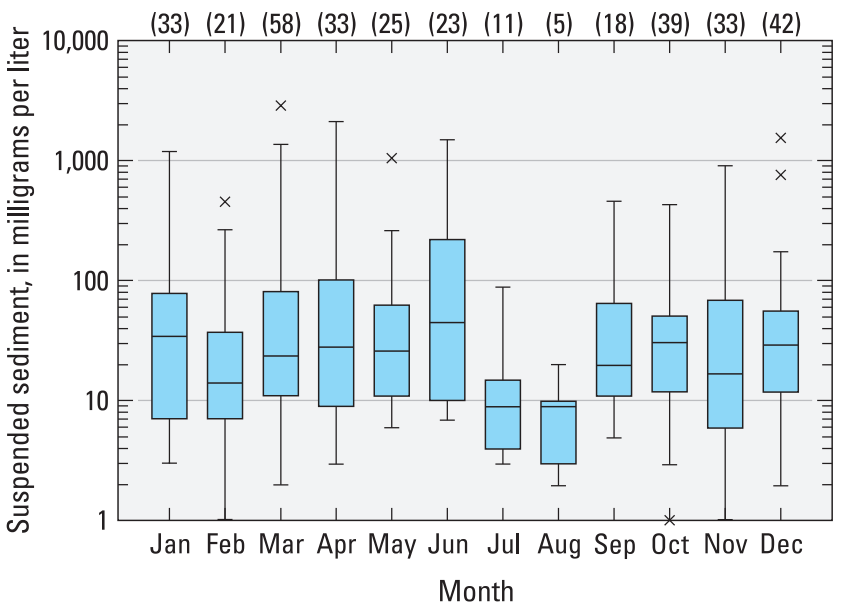

Figure 12. Monthly variation in suspended-sediment concentrations, discrete water-quality samples, Mattawoman Creek, 2001-10.

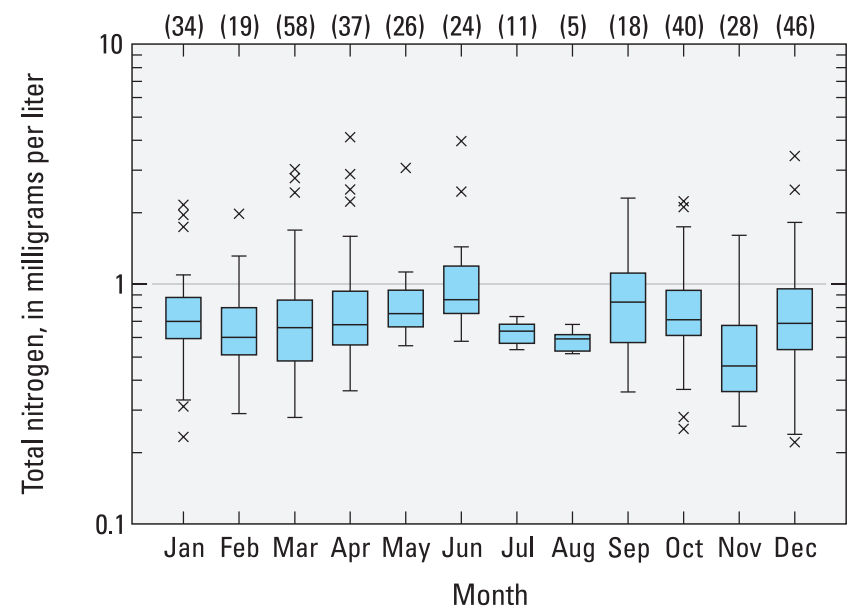

Figure 14. Monthly variation in total nitrogen concentrations, discrete water-quality samples, Mattawoman Creek, 2001-10.

\section{EXPLANATION}

(31) Number of samples

$\times$ OUTLIER DATA VALUE (greater than 1.5 times the IQR outside the quartile)

Data value within 1.5 times the IQR outside the quartile

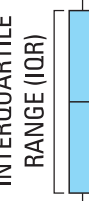

75th PERCENTILE (75 percent of the data values are less than this value)

Median

25th PERCENTILE (25 percent of the data values are less than this value) 
organic fraction (table 2). Thus, the similarity of the seasonal pattern for total nitrogen to the seasonal pattern of sediment and total phosphorus implies that either dissolved organic nitrogen is mobilized by the same physical processes that mobilize sediment and particulate phosphorus, or a biological transformation of nitrogen is acting in seasonal step with the physical processes underlying the observed monthly patterns for sediment and phosphorus.

Speciation of phosphorus at Mattawoman Creek showed little seasonal variability, with monthly patterns in the proportions of dissolved inorganic, dissolved organic, and particulate phosphorus very similar to the monthly pattern of median concentrations in the aggregate data discussed earlier (fig. 15). The key factors influencing seasonality in the total concentration and speciation of phosphorus in forest streams include delivery from the terrestrial environment, transformation of dissolved inorganic phosphorus into particulate phosphorus through plant and microbial assimilation, sorption/desorption onto particulates, precipitation and dissolution, and channel transport (Withers and Jarvie, 2008). Conclusively determining the relative importance of these mechanisms in a given setting and season generally involves targeted direct process measurements. Because of the strong tendency for phosphorus to associate with particulate matter, the same physical mechanisms responsible for seasonal trends in suspended-sediment concentration probably influence phosphorus. Assimilative transformation of inorganic phosphorus into particulate organic phosphorus during the growing season could be an additional biological factor underlying the observed seasonal pattern in particulate and, by extension, total phosphorus concentration in Mattawoman Creek. If so, the relative constancy of the species' proportions throughout the year could reflect the continuous buffering effect of concentration-dependent sorption-desorption processes (Allen, 1995). The distinct
October peak in particulate phosphorus may be associated with input of fallen leaves.

In contrast to seasonal patterns for phosphorus, seasonal patterns in nitrogen speciation, particularly for dissolved inorganic and dissolved organic nitrogen, are clearly evident (fig. 16). The decreasing trend in dissolved inorganic nitrogen between February and August likely reflects increasing demand for incorporation of this biologically available form into living biomass as the growing season proceeds. Similarly, the increase in dissolved organic nitrogen, and, by extension, total nitrogen during the growing season is also characteristic of increased biological activity, reflecting animal excretion and cell lysis associated with decomposition of plant and animal tissue (Allen, 1995; Jorgensen, 2009). The pattern could also be indicative of delivery of dissolved organic nitrogen to the channel (for example from the flood plain or other upland sources) by the same mechanism underlying the seasonal pattern in suspended-sediment concentration (fig. 12). Fallen leaves are an important terrestrial source of carbon for forested streams, and the particularly low value of dissolved inorganic nitrogen in November may reflect a pulse in demand, resulting from increased heterotrophic activity associated with leaf decomposition (Allen, 1995).

\section{Interrelations between Physical Parameters, Nutrients, and Suspended Sediment}

The strength and direction of correlation relations between physical water-quality parameters, and nutrients and suspended sediment can provide insights into the first-order controls on water quality. Relations in this study were evaluated both visually and statistically; a summary correlation matrix is shown in table 3 . Many variables had positively

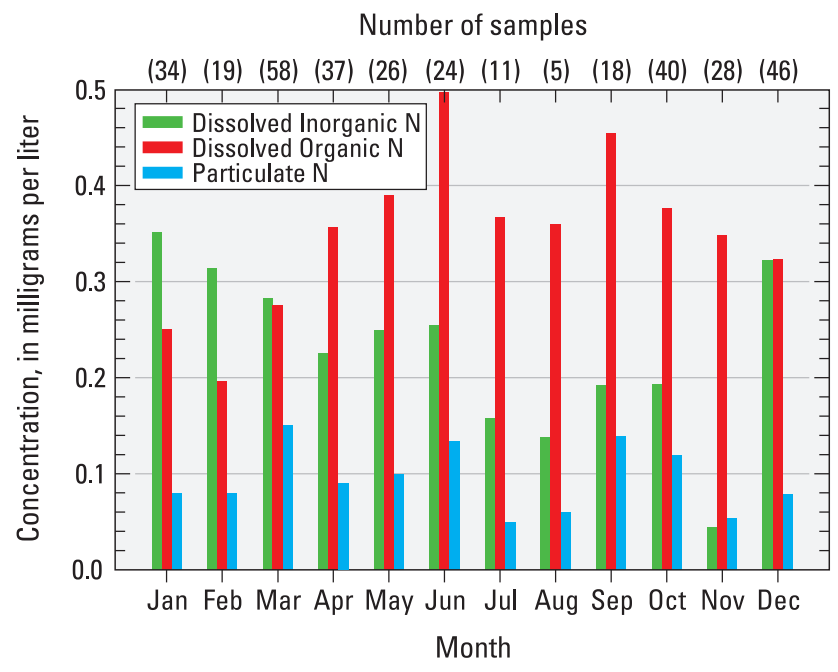

Figure 16. Monthly variation in median concentrations of major nitrogen species, Mattawoman Creek, 2001-10.
Figure 15. Monthly variation in median concentrations of major phosphorus species, Mattawoman Creek, 2001-10.

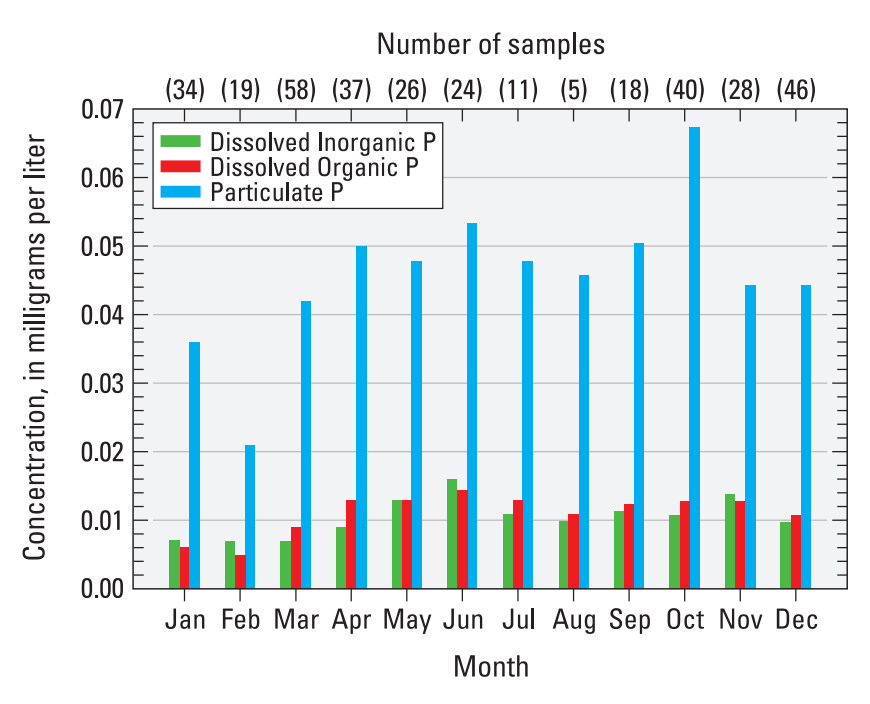

Number of samples

sorption-desorption processes (Allen, 1995). The distinct 
skewed distributions; to emphasize linear relations, these variables were log-transformed. Also, in order to clarify natural watershed relations, and based on the strong evidence of anthropogenic chloride enrichment from road salt (fig. 9f), values of specific conductance above $160 \mu \mathrm{S} / \mathrm{cm}$ were censored for purposes of correlation and regression analysis. This threshold was selected on the basis of (1) examination of a plot of continuous specific conductance compared to discharge, which revealed that observations above about 160 $\mu \mathrm{S} / \mathrm{cm}$ only occurred as distinct episodic excursions, and (2) a monthly histogram of the number of continuous specific conductance observations exceeding $160 \mu \mathrm{S} / \mathrm{cm}$, which indicated the greatest frequency in January through March, and no instances between July and September.

The most evident features in table 3 are the strong positive correlations between total nitrogen, total phosphorus, and suspended sediment, in the range of $0.80-0.84$. Correlations of this strength may indicate that the same mechanisms responsible for mobilizing and transporting sediment also are responsible for mobilizing and transporting nutrients. As discussed earlier, this hypothesis would be strongly supported if both phosphorus and nitrogen were predominantly in particulate form; however, particulate nitrogen constituted the smallest proportion of total nitrogen, on average (table 2). Particulate nitrogen was weakly positively correlated with both dissolved inorganic and dissolved organic nitrogen $(r=0.33$ and 0.31 , respectively; data not shown). Thus, even in the absence of a conclusive biogeochemical interpretation, the results are statistically plausible.

Regarding the continuous water-quality parameters, the strong negative correlation between temperature and dissolved oxygen $(\mathrm{r}=-0.83$; table 3$)$ is a consequence of the nearly oxygen-saturated conditions that predominate year round at Mattawoman (figs. 9c, d). The decrease in $\mathrm{pH}$ with increasing discharge $(r=-0.68)$ is a consequence of the chemistry of precipitation and the buffering capacity of watershed minerals. Although significant progress has been made in reducing atmospheric sources of acidity, the northeastern United States still receives some of the most acidic precipitation of any area in the country (National Atmospheric Deposition Program, 2011). Acid-buffering capacity in the conterminous United States can range from under 50 microequivalents per liter $(\mu \mathrm{eq} / \mathrm{L})$ to over $400 \mu \mathrm{eq} / \mathrm{L}$ (Omernik and others, 1988). Buffering capacity of water in the Mattawoman Creek watershed is estimated to be between 100-200 $\mu \mathrm{eq} / \mathrm{L}$ (Hall and Matthews, 1974), which is considered moderate. In the absence of strong buffering capacity, the negative correlation between $\mathrm{pH}$ and discharge can be conceptualized approximately as a mixing process. With road-salt censoring applied to specific conductance, a positive relation between $\mathrm{pH}$ and specific conductance becomes evident, along with corresponding negative relations between conductance and discharge $(\mathrm{r}=+0.61$ and -0.54 , respectively; table 3$)$. Taken together with the previous discussion of water-column specific conductance as the product of a mixing process, the correlations between both of these properties and discharge can be interpreted in terms of mixing of acidic but dilute (in terms of dissolved solids, reflected as low conductance) rainfall, with $\mathrm{pH}$-neutral groundwater higher in dissolved solids.

In terms of practical utility for regression modeling, turbidity shows a strong positive correlation with total nitrogen, total phosphorus, and suspended sediment, with correlation coefficients for log-log relations in the range 0.76-0.81 (table 3 ). This is a direct outcome of the tendency for suspended material to scatter light. It also appears that discharge may have some utility as a predictor for suspended sediment; however, turbidity is positively correlated with discharge, so the predictors may provide some amount of redundant

Table 3. Pearson correlation coefficients between and among physical water-quality parameters, nutrients, and suspended sediment, Mattawoman Creek.

[Correlation coefficients greater in magnitude than 0.60 are shaded; $\mathrm{ft}^{3} / \mathrm{s}$, cubic feet per second; ${ }^{\circ} \mathrm{F}$, degrees Fahrenheit; FNU, Formazin Nephelometric Units; $\mathrm{mg} / \mathrm{L}$, milligrams per liter; $\mu \mathrm{S} / \mathrm{cm}$, microseimens per centimeter; N, nitrogen; $\mathrm{P}$, phosphorus]

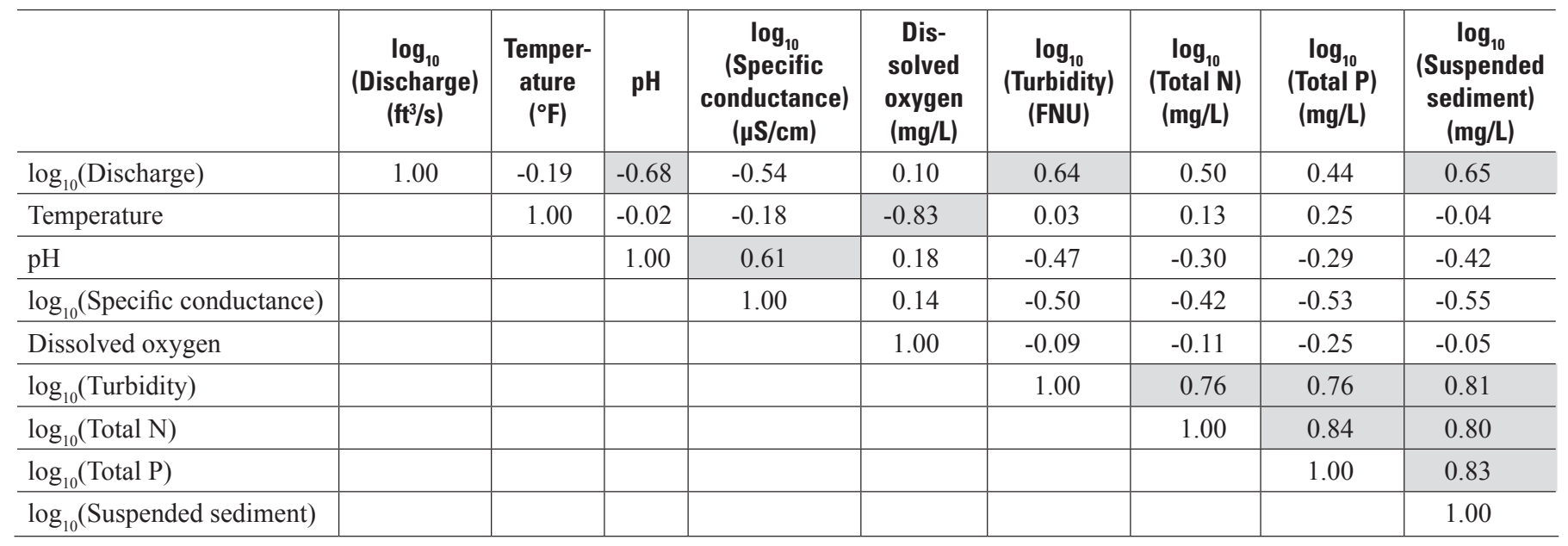


information. Relations between predictors including discharge and turbidity, and response variables such as total nitrate, total phosphorus, and suspended sediment, are explored in more detail in the section Estimation of Continuous Concentrations of Nutrients and Suspended Sediment.

\section{Comparisons between Watersheds- Concentration Data}

Distributions of concentration data for Mattawoman Creek, the four comparison watersheds, and the Potomac River from 2000 through 2010 are shown in figure 17. The distribution of sediment and phosphorus was similar among watersheds, reflecting the predominantly particle-reactive nature of the latter. For both constituents, the highest concentrations occurred in the Northwest Branch Anacostia River. This is a factor of both supply (for example, construction) and transport capacity (for example, stream channelization) in this highly urban watershed (Miller and others, 2007; Walsh and others, 2005). Concentration ranges for the other five watersheds had a substantial degree of overlap (fig. 17). Mattawoman Creek had the second highest median suspendedsediment concentration and the third highest median total phosphorus concentration. This could reflect anthropogenic sediment and, as discussed in the Introduction, legacy phosphorus (Paul and Meyer, 2001; Ator and others, 2011).

However, the limited record of difference in continuous turbidity between the operational sonde deployed throughout this study and the temporary sonde deployed in 2011 (for about 4 months; fig. 7) shows several large storm-related pulses recorded by the operational sonde, sampling just downstream of the mouth of Old Womans Run, that were not evident in data from the temporary sonde, which was presumed to be more representative of the Mattawoman main stem. Turbidity is a good surrogate for nutrients and sediment at Mattawoman Creek (table 3). This indicates that sediment and phosphorus concentrations in discrete samples collected at LEW may also be biased high relative to concentrations in the main stem. The results of the sediment loading and sediment source fingerprinting study conducted nearby on Mattawoman Creek by Gellis and others (2009) support this contention. However, they employed a sampling scheme more suited to comparing loads and yields, rather than concentrations; implications of the results are discussed in the section on Estimation of Nutrient and Suspended-Sediment Loads and Yields. The North Branch Patapsco River had the lowest median concentrations of both sediment and phosphorus (fig. 17), an unexpected result in light of the proportion of agricultural land cover in the basin (52 percent; table 1).

Nitrogen concentration is generally enriched by several source factors including manure and fertilizers in agriculture and fertilizers and sewage sources in urban areas, but physical conditions along groundwater-flow paths also are important. Nitrogen concentrations in Mattawoman Creek are lower than those in any of the comparison watersheds (fig. 17).
Concentrations of nitrogen are highest at the North Branch Patapsco River. As discussed earlier, the dominant species of nitrogen at Mattawoman was dissolved organic nitrogen; in contrast, total nitrogen in the Patapsco River is overwhelmingly inorganic, with a median total nitrogen concentration of $4.0 \mathrm{mg} / \mathrm{L}$ and a median nitrate-plus-nitrite concentration of 3.4 $\mathrm{mg} / \mathrm{L}$ (data not shown). The differences are caused by at least two factors - first, heavily agricultural land use in the Patapsco watershed has likely elevated groundwater nitrate levels relative to the largely forested Mattawoman watershed. Second, wetland conditions on the Mattawoman flood plain - broad, flat, poorly drained and rich in organic matter-favor long residence times and the development of reducing conditions favorable to denitrification (Krantz and Powars, 2000; Ator and others, 2005). The highly urbanized Northwest Branch Anacostia River also had high total nitrogen concentrations (fig. 17). Dissolved organic nitrogen was the smallest component of total nitrogen at this site (about 15 percent; median dissolved organic and total nitrogen concentrations were 0.39 $\mathrm{mg} / \mathrm{L}$ and $2.4 \mathrm{mg} / \mathrm{L}$, respectively); particulate and inorganic nitrogen were co-dominant (median concentrations were 1.2 $\mathrm{mg} / \mathrm{L}$ and $1.0 \mathrm{mg} / \mathrm{L}$, respectively; data not shown).

\section{Estimation of Continuous Concentrations of Nutrients and Suspended Sediment}

Regression model equations and model statistics for suspended sediment, total phosphorus, and total nitrogen at Mattawoman Creek are shown in table 4; plots of observed and predicted values for the three models are shown in figures 18-20. For comparison, table 4 also presents models constructed by Miller and others (2007) for the same constituents at the Northeast Branch Anacostia River at Riverdale, Maryland (USGS station number 01649500) and the Northwest Branch Anacostia River near Hyattsville, Maryland (USGS station number 01651000). In all three Mattawoman models, the model residuals in log-log space showed evidence of modest deviation from a normal (Gaussian) distribution; specifically, diagnostic plots revealed higher-than-expected incidences of both high and low outliers. In only a few cases, examination of field and laboratory remarks for the corresponding observations provided justification for their removal. Moreover, the situation was not improved by considering standard data transformations other than logarithms. The outliers could be indicative of natural variability in the environmental system, or they could be related to sampler intake location, as discussed in the QA section on lateral mixing. The deviation from the assumption of normally distributed residuals undermines (1) the validity of formal hypothesis tests for the significance of model parameters, and (2) the estimation of uncertainty, in terms of confidence and prediction intervals, of estimated values (Helsel and Hirsch, 1992). 

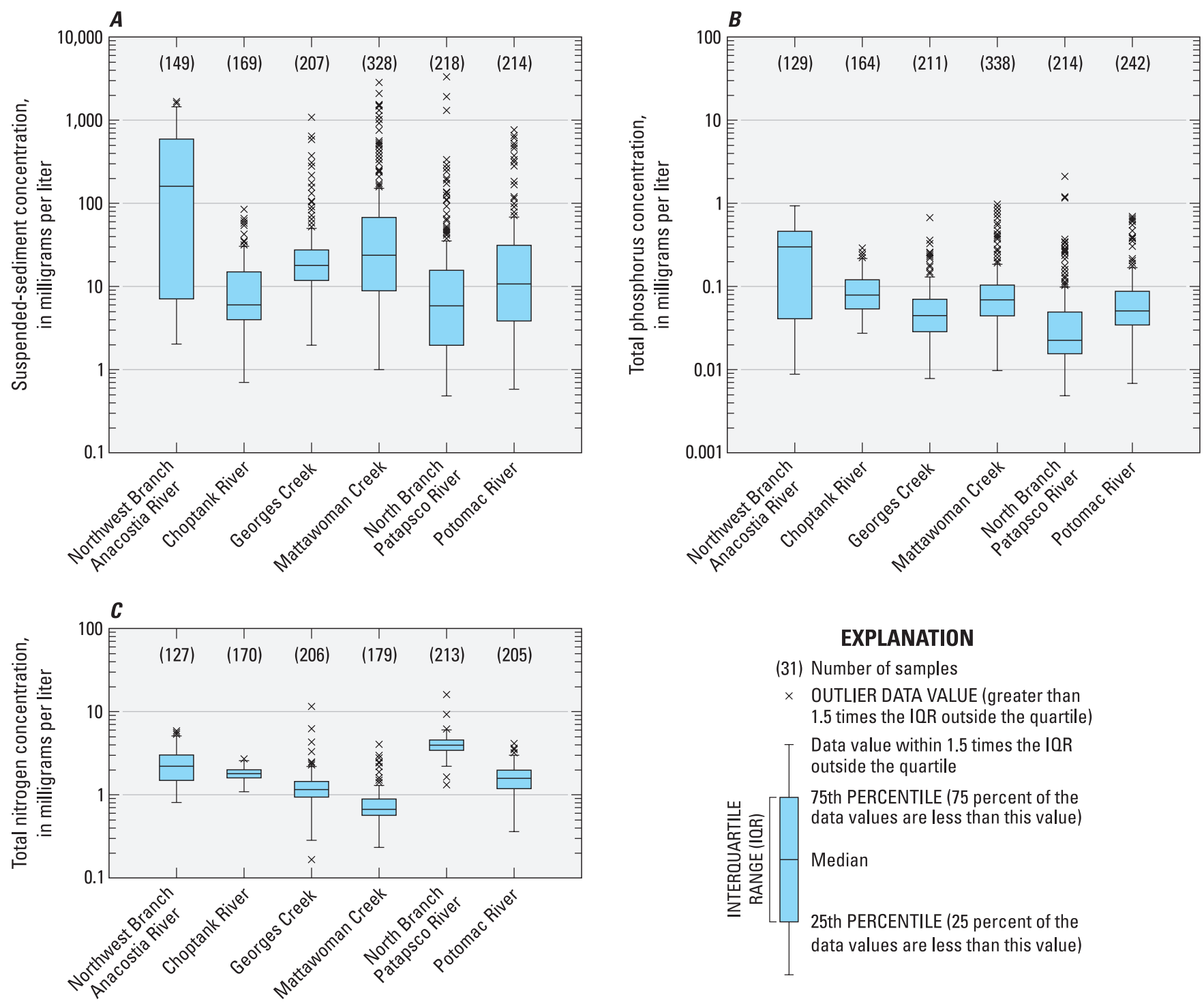

Figure 17. Boxplots comparing distributions of concentration data from Mattawoman Creek with data from four comparison watersheds, and the Potomac River, 2000-10 (A) suspended sediment (total suspended solids for Georges Creek and Patapsco River, see text); $(B)$ total phosphorus; and $(C)$ total nitrogen.

\section{Suspended Sediment}

The model for suspended sediment at Mattawoman Creek included terms for both turbidity and discharge (table 4). This was also the case for sediment models constructed by Miller and others (2007) using the same approach for the Northeast and Northwest Branches of the Anacostia River. In all three cases, coefficients on both predictors were positive, possibly indicating a common basis for their selection. One plausible explanation lies in the physics of sediment entrainment and transport: higher bed shear stresses associated with higher discharges are capable of moving relatively coarser bed material, which has smaller surface-area-to-weight ratio and therefore influences turbidity less than an equivalent weight of the generally finer material transported at lower discharges. As a result, the common positive coefficient on discharge may be interpreted as elevating the estimate of suspended sediment above what might be expected from turbidity alone at high discharge. The model has a degree of negative relative bias [-10 percent, computed as (mean of estimated values - mean of observed values) * 100 / (mean of observed values); table 4]; this is also evident as a somewhat higher frequency of large under-predictions, relative to large over-predictions, in a 1:1 plot of observed and predicted values (fig. 18). An alternate model for suspended sediment based only on turbidity had much smaller bias, +0.4 percent, with a slightly lower $\mathrm{R}^{2}$ (72 percent compared to 76 percent; alternate model results not shown). However, inspection of the distribution of model 
Table 4. Regression models for concentrations of suspended sediment, total phosphorus, and total nitrogen, Mattawoman Creek, with corresponding models for Northeast and Northwest Branches of the Anacostia River near Washington, D.C. for comparison.

[USGS, U.S. Geological Survey; mg/L, milligrams per liter; SS, concentration of suspended sediment in mg/L; TP, concentration of total phosphorus in mg/L; $\mathrm{TN}$, concentration of total nitrogen in $\mathrm{mg} / \mathrm{L}$; Q, discharge in cubic feet per second; Turb, turbidity in Formazin Nephelometric Units (FNU); $\mathrm{R}^{2}$, coefficient of determination]

\begin{tabular}{|c|c|c|c|c|}
\hline Constituent & Regression equation & $\begin{array}{c}\text { Adjusted } \\
\mathbf{R}^{2}\end{array}$ & $\begin{array}{l}\text { Actual } \\
\text { relative bias }^{1} \\
\text { (percent) }\end{array}$ & $\begin{array}{l}\text { Degrees of } \\
\text { freedom }\end{array}$ \\
\hline \multicolumn{5}{|c|}{ Mattawoman Creek (USGS station number 01658000) } \\
\hline Suspended sediment (mg/L) & $\log _{10}(\mathrm{SS})=0.0005+0.9125 * \log _{10}($ Turb $)+0.2152 * \log _{10}(\mathrm{Q})$ & 0.76 & -9.9 & 185 \\
\hline Total phosphorus (mg/L as $\mathrm{P}$ ) & $\log _{10}(\mathrm{TP})=-1.7392+0.5377 * \log _{10}($ Turb $)$ & 0.68 & -4.0 & 186 \\
\hline Total nitrogen (mg/L as $\mathrm{N})$ & $\log _{10}(\mathrm{TN})=-0.5177+0.3194 * \log _{10}($ Turb $)$ & 0.61 & -1.4 & 186 \\
\hline Suspended sediment $(\mathrm{mg} / \mathrm{L})$ & $\log _{10}(\mathrm{SS})=-0.8655+0.4228 * \log _{10}($ Turb $)+0.8201 * \log _{10}(\mathrm{Q})$ & 0.95 & -5.5 & 70 \\
\hline Total phosphorus (mg/L as $\mathrm{P}$ ) & $\log _{10}(\mathrm{TP})=-2.0342+0.2798 * \log _{10}($ Turb $)+0.2924 * \log _{10}(\mathrm{Q})$ & 0.88 & -3.7 & 61 \\
\hline Total nitrogen $(\mathrm{mg} / \mathrm{L}$ as $\mathrm{N})$ & $\log _{10}(\mathrm{TN})=0.0419+0.1427 * \log _{10}($ Turb $)$ & 0.67 & -3.8 & 68 \\
\hline \multicolumn{5}{|c|}{ Northwest Branch Anacostia River (USGS station number 01651000)² } \\
\hline
\end{tabular}

residuals in linear space indicated that the difference in mean bias between the two models was highly influenced by only one or two outlying observations; for this reason, the apparent large bias was not taken as a sufficient basis for rejecting the model based on turbidity and discharge.

The regression model for suspended sediment at Mattawoman Creek had somewhat poorer explanatory power relative to the corresponding models identified for the Anacostia watersheds (adjusted $\mathrm{R}^{2}$ values of 0.76 for Mattawoman compared to 0.95 for both the Northeast and Northwest Branch Anacostia; table 4). One possible explanation is the issue of sampler location relative to the mouth of Old Womans Run. Since discharges of highly turbid water associated with early peaks from Old Womans Run tend to occur well before peak discharge from the Mattawoman main stem (fig. 6), it may be that samples gathered early on a storm hydrograph where such input is significant may reflect higher turbidity values for a given discharge than might be observed otherwise due to the incomplete mixing. This bias due to sampling location would result in a generally more variable dataset than would have been observed if mixing were not an issue. However, there are other plausible reasons why a sediment model at Mattawoman might not perform as well as those identified for Anacostia. Differences in the underlying lithology of the watersheds, with both Anacostia basins lying at least in part on crystalline Piedmont rocks and the Mattawoman watershed lying entirely on Coastal Plain sediments, may also play a role. The sandy nature of the floodplain sediment and the streambed itself, along with the shifting nature of the streambed and consequent tendency of the streambed elevation to shift in the vicinity of the sampler, may contribute to a generally more variable dataset. Finally, the Anacostia watersheds are extremely urbanized relative to the Mattawoman watershed. This has undoubtedly led to changes in the channel structure and sediment regime, both indirectly through changes in the hydrologic regime (such as increased peak flows and consequent channel degradation), and directly as evidenced by ubiquitous instances of channelized reaches and engineered stabilization measures. It is therefore entirely plausible that urbanization in the Anacostia watersheds has led to a less variable, more predictable relation between discharge, turbidity, and suspended sediment than the relation that is evident at Mattawoman Creek.

\section{Total Phosphorus}

The stepwise model selection for total phosphorus at Mattawoman only identified turbidity as a robust predictor (table 4; fig. 19). This contrasts with the model for suspended sediment at Mattawoman, and the models for phosphorus at both Anacostia watersheds, which included both turbidity and discharge. Phosphorus tends to strongly sorb to particulate matter; hence, the identification of turbidity has a plausible 


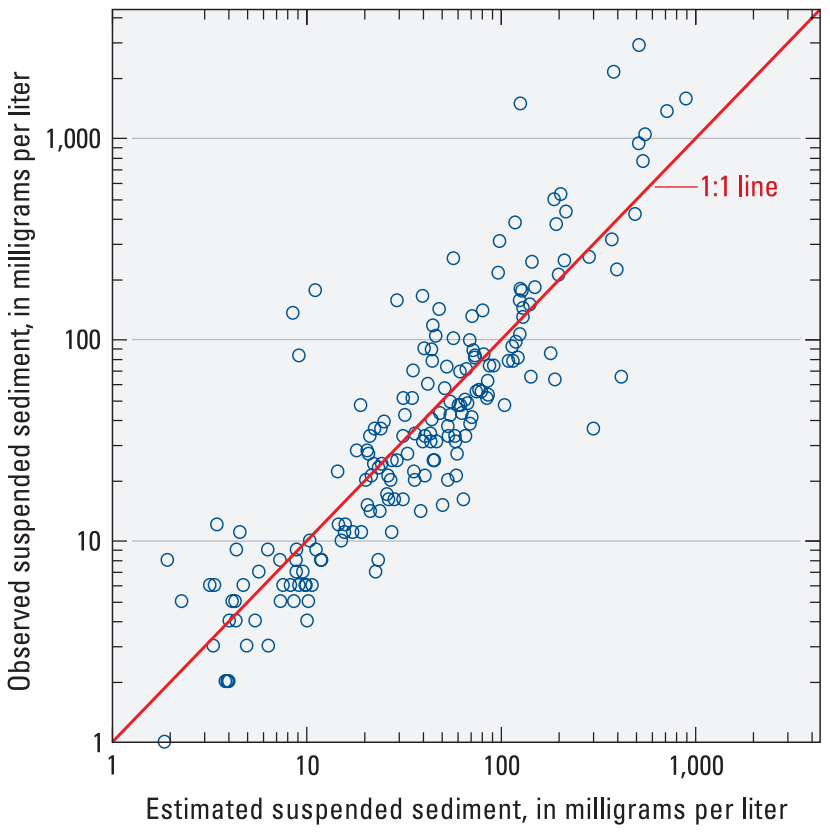

Figure 18. Comparison of observed suspended-sediment concentrations at Mattawoman Creek with values predicted by model equation shown in table 4 .

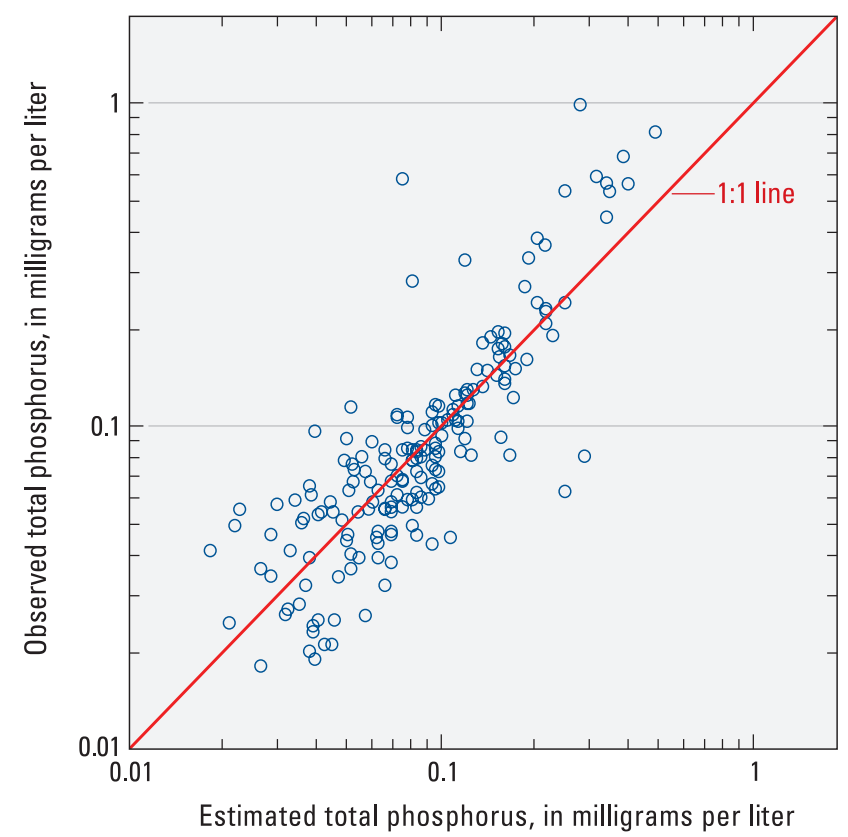

Figure 19. Comparison of observed total phosphorus concentrations at Mattawoman Creek with values predicted by model equation shown in table 4 .

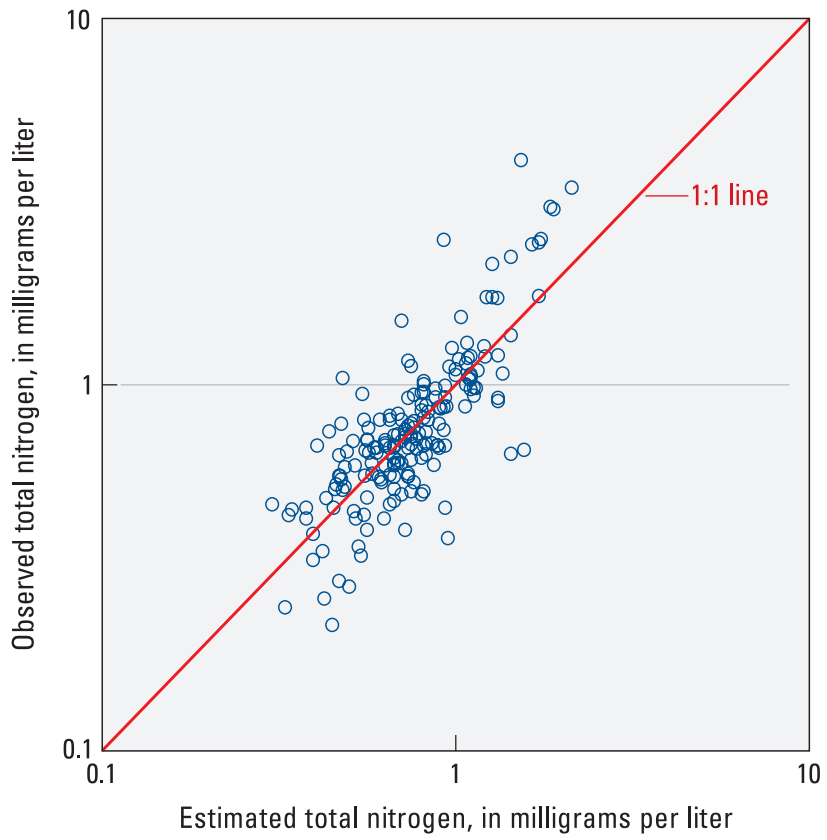

Figure 20. Comparison of observed total nitrogen concentrations at Mattawoman Creek with values predicted by model equation shown in table 4 . physical interpretation. However, this particle affinity, ultimately related to electrical charge on the particles' surface, is a significant phenomenon only with particles of clay size and smaller. Thus, whereas sand-sized material mobilized by high discharge would contribute to measured sediment mass, it would not significantly increase phosphorus concentration. The significance of a discharge term in the models for the Anacostia watersheds may be related to their high degree of urbanization, with associated wet-weather sources such as street wash-off and CSOs.

\section{Total Nitrogen}

Turbidity was selected as the only robust predictor of total nitrogen at Mattawoman Creek (table 4). Of the three constituents for which models were constructed, the nitrogen model had the poorest explanatory power $\left(\mathrm{R}^{2}=0.61\right.$, compared to 0.68 and 0.76 for phosphorus and sediment, respectively); this was also the case for both Anacostia watersheds (table 4). The most likely explanation for the relative unpredictability of total nitrogen is its reactivity: it can assume more forms and undergoes more transformations than the other two constituents. Notably, the difference in the explanatory power of the nitrogen model, relative to the sediment and phosphorus models, was much smaller than the corresponding difference for the models developed for the Anacostia watersheds (for 
example, a difference in $\mathrm{R}^{2}$ of about -7 percent relative to the phosphorus model for Mattawoman, compared to well over -20 percent for the corresponding Anacostia models). One hypothesis is that delivery pathways for nitrogen and phosphorus are more similar at Mattawoman than at the Anacostia watersheds.

\section{Estimation of Nutrient and Suspended- Sediment Loads and Yields}

On the basis of data collected since October 2000, estimates of mean annual load in pounds expressed as a mean daily flux for Mattawoman Creek computed using LOADEST compared closely to those published by the NTN Program (table 5). This confirms that the implementation of the sevenparameter regression model in LOADEST is essentially equivalent to the implementation used by the RIM and NTN Programs. Estimates were nearly identical for total nitrogen, differed in mean value by about 2 percent for total phosphorus, and differed in mean value by about 6 percent for suspended sediment. Small differences could be attributed to slight differences in the number of observations considered by the two studies, which also influence the value used to "center" time and discharge terms in the regression model. The pattern in magnitude of mean differences between NTN Program and LOADEST estimates (nitrogen less than phosphorus less than sediment) parallels the pattern in model explanatory power $\left(\mathrm{R}^{2}\right)$, which was 96,91 , and 86 percent, respectively, for the load models computed by LOADEST. This indicates that sensitivity of the two methods to small differences in data may be a function of the quality of the model fit. As was the case with the regressions relating nutrients and sediment to continuous surrogates, both NTN Program and LOADEST model residuals for all three constituents showed signs of deviation from the assumed normal distribution. Also, residuals in models for nitrogen and phosphorus had serial correlation coefficients just over 0.3 (data not shown), indicating a mild deviation from the assumption of independent observations. Violation of this assumption can introduce bias into model parameter estimates and undermine the validity of confidence intervals on model predictions (Helsel and Hirsch, 1992).

Annual LOADEST estimates of flux for suspended sediment, total phosphorus, and total nitrogen based on daily discharge data (the same estimates shown in table 5) with corresponding estimates based on hourly discharge data are shown in figures 21 a-c. Regardless of time step, year-to-year patterns in loading for all three constituents closely resemble the year-to-year pattern in mean annual discharge for the same period (fig. 8b). This underscores the importance of flow as a first-order control on loading. Its significance stems from two mechanisms: first, since water is the transport medium for all constituents, higher flows at any given concentration result in higher loading. Second, the concentration of all three constituents examined here is positively correlated with flow (see

Table 5. Comparison of annual loading estimates made during this study with estimates made in 2010 by the U.S. Geological Survey for Mattawoman Creek as a component of the Chesapeake Bay Program Nontidal Monitoring Network (NTN).

[NTN estimates compare status and trends from 9 large and approximately 40 smaller Bay tributaries using a common data acquisition and analysis protocol (Langland and others, 2012). Estimates are routinely updated; current estimates are available online at http://cbrim.er.usgs.gov. Annual loads are expressed as an average daily flux.]

\begin{tabular}{|c|c|c|c|c|c|c|c|c|c|}
\hline \multirow{2}{*}{$\begin{array}{l}\text { Water } \\
\text { year }\end{array}$} & \multicolumn{9}{|c|}{$\begin{array}{l}\text { Estimated daily flux } \\
\text { (pounds per day) }\end{array}$} \\
\hline & \multicolumn{3}{|c|}{ Suspended sediment } & \multicolumn{3}{|c|}{ Total phosphorus } & \multicolumn{3}{|c|}{ Total nitrogen } \\
\hline 2002 & 1,300 & 1,200 & 8 & 2.9 & 2.6 & 10 & 33 & 33 & 0 \\
\hline 2003 & 88,000 & 88,000 & 0 & 82 & 83 & -1 & 630 & 630 & 0 \\
\hline 2005 & 55,000 & 52,000 & 5 & 46 & 45 & 2 & 360 & 360 & 0 \\
\hline 2006 & 72,000 & 68,000 & 6 & 58 & 58 & 0 & 340 & 340 & 0 \\
\hline 2007 & 84,000 & 78,000 & 7 & 56 & 54 & 4 & 380 & 380 & 0 \\
\hline 2008 & 63,000 & 56,000 & 11 & 48 & 47 & 2 & 320 & 320 & 0 \\
\hline
\end{tabular}

${ }^{1}$ Quality-control data collected in 2011 indicate that reported annual fluxes of sediment and particulate nutrients at Mattawoman Creek may be overestimates; see section Comparisons between Watersheds_-Load Data for discussion. 

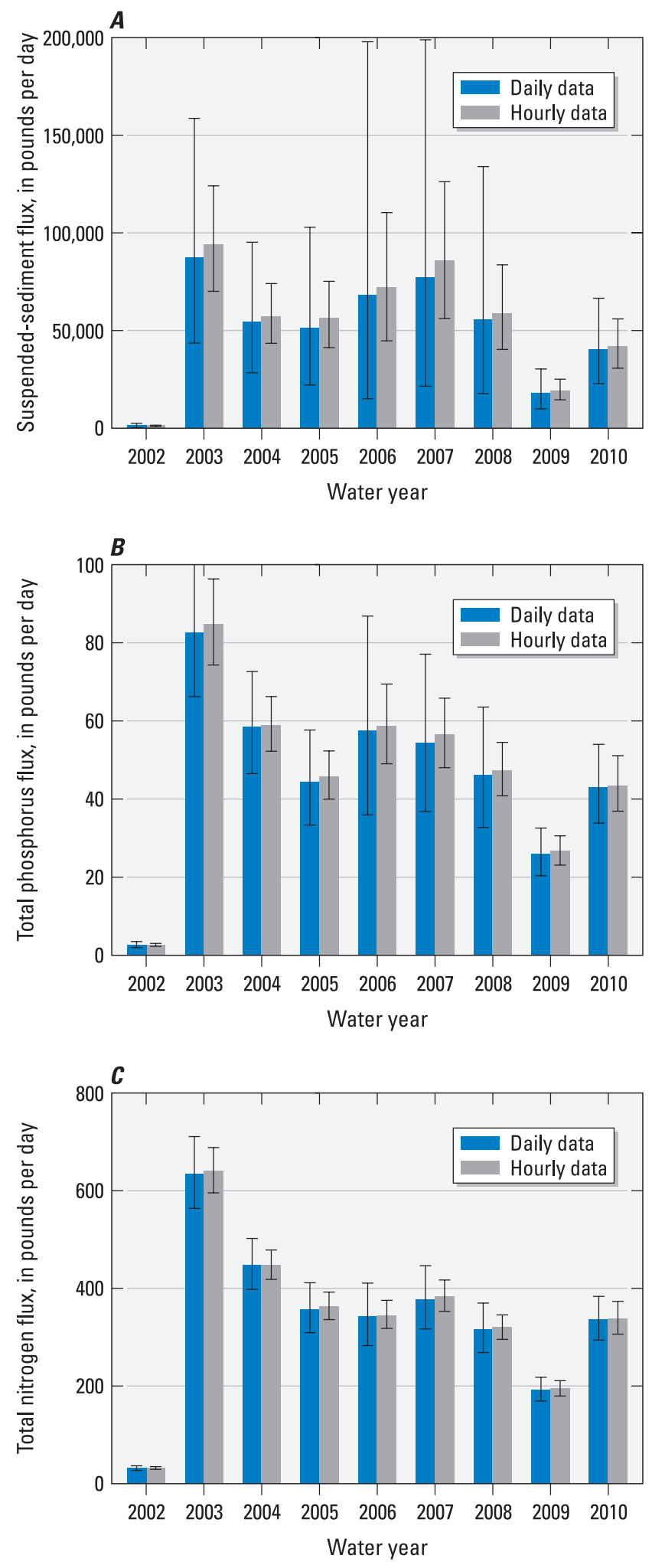

Figure 21. LOADEST estimates of flux for suspended sediment, total phosphorus, and total nitrogen, Mattawoman Creek, water years 2002-10, comparing estimates based on daily and hourly time steps. Whiskers indicate 95-percent confidence intervals $(A)$ suspended sediment, $(B)$ total phosphorus, and (C) total nitrogen. table 3). Therefore, the coefficients on the flow terms in the regression equations are positive, so higher flows correspond to higher estimated concentrations.

In any year, differences between annual load estimates based on daily and hourly discharge data are generally small; estimates based on hourly data are slightly larger than corresponding estimates based on daily data (fig. 21). The largest differences are evident for suspended sediment. The reduction in the widths of the 95-percent confidence intervals around the total load estimates is more significant - in the case of total phosphorus and suspended sediment, confidence intervals are generally over a factor of two narrower for estimates based on hourly data than daily data. This decrease in the width of the confidence intervals, which results simply by moving from daily to hourly discharge time steps, stems from LOADEST model assumptions related to aggregating autocorrelated load estimates made at daily rather than sub-daily time steps.

The established significance of turbidity as a surrogate for both sediment and nutrients (table 4) indicates that loading estimates may be improved by incorporating turbidity into the underlying regression equations. A set of three eight-parameter LOADEST models was estimated by adding log-transformed turbidity to the set of seven parameters used in the load models for nitrogen, phosphorus, and sediment discussed earlier. These models were then applied to estimate loads using discharge and turbidity at hourly time steps, with hourly turbidity computed as the arithmetic mean of (typically) four 15-minute observations. This makes it possible to compare load estimates from three models: a discharge-only model run at a daily time step, a discharge-only model run at an hourly time step, and an hourly model incorporating both discharge and turbidity. Ideally, these comparisons would be made on mean annual estimates, such as those shown in figure 21. However, sensor maintenance issues inevitably result in gaps in the continuous record for turbidity. The study period began October 7, 2003 (the date the turbidity sensor was deployed) and continued through January 10, 2011; considering only the 15-minute intervals when there was measureable discharge, coverage of the turbidity sensor was 79.7 percent. Although many of these gaps were on the order of 15 minutes to several hours, and could arguably be filled by interpolation, between-model comparisons of annual loads would ultimately be qualified by the method used to fill in the larger gaps in order to produce an unbroken turbidity record. As an alternative, a 58-day period with a nearly unbroken quality-controlled record of both discharge and turbidity was identified. Two missing 15-minute observations were estimated to form a complete record. The period included several small storm events, the largest with a peak flow of $417 \mathrm{ft}^{3} / \mathrm{s}$, as well as extended periods of low flow. The total load for this period, January 6 through March 6, 2009 , was estimated using each of the three models (daily discharge, hourly discharge, and hourly discharge with turbidity) for total nitrogen, total phosphorus, and suspended sediment.

For all three constituents, regression diagnostics improved somewhat in hourly models with turbidity as an added predictor; in particular, subjective assessment of 
residual histograms and Q-Q plots indicated significantly improved fit to a normal distribution, although four-six high outliers remained for all constituents. Assessment of the variance inflation factor (VIF) regression diagnostic indicated that correlation between turbidity and discharge (table 3 ) was not a significant concern. As expected, adding turbidity as a predictor increased model explanatory power, most notably in the case of suspended sediment, where model $\mathrm{R}^{2}$ rose from 0.85 to 0.94 (table 6). Estimated loading, expressed for all three constituents as an average daily flux over the 58-day period (table 7) and for sediment, as a total flux (fig. 22b), was somewhat smaller in models that included turbidity. Given that turbidity typically peaks on the rising limb of the storm hydrograph, the smaller estimates may result from the associated limitation of models based on discharge alone, which generally predict the same loading for equal discharges on both the rising and falling limbs of the hydrograph (fig. 22). Whereas the largest decreases in confidence-interval width were still associated with transitioning from daily to hourly time steps, adding turbidity as a predictor further decreased this measure of uncertainty by 14-19 percent relative to daily time steps (table 7). Unlike the reductions discussed earlier, which were associated with LOADEST assumptions related to estimation time step (fig. 21), improvements associated with adding turbidity reflect reduced regression residual variance.
Results of this component of the study were consistent with the findings of others who performed similar loading comparisons. Jastram and others (2009) found that estimated monthly and annual suspended-sediment loads for the James River at Cartersville, Virginia, tended to decrease for a model including discharge, turbidity, and water temperature, relative to the standard seven-parameter discharge model used by the RIM and NTN Programs; prediction uncertainty decreased as well. Working in several Kansas rivers, Rasmussen and others (2005) also found that suspended-sediment estimates based on turbidity alone were considerably smaller than estimates based on discharge alone; the authors also speculated that the difference was due to concentration-discharge hysteresis, as discussed earlier. Miller and others (2007) observed decreased uncertainty in estimates of suspended sediment, based on turbidity and discharge, in the highly urbanized Northeast and Northwest Branches of the Anacostia River, but found that the estimated load of all constituents increased relative to estimates produced by the standard seven-parameter model using only discharge. This discrepancy with the findings of Jastram and others (2009) and Rasmussen and others (2005) may be related to the extraordinarily high suspended-sediment yields (load per unit area) from these watersheds, which exceeded yields of any of the other RIM watersheds by roughly an order of magnitude (Langland and others, 2012).

Table 6. Regression model coefficients (p-values), and model performance statistics for LOADEST models, comparing models constructed using seven parameters with models constructed using turbidity as an eighth parameter.

[ln, natural logarithm; n, number of observations; Q, discharge in cubic feet per second; QC, central value of discharge in cubic feet per second; T, time in years; TC, central value of time in years; Turb, turbidity in Formazin Nephelometric Units (FNU); $\mathrm{R}^{2}$, coefficient of determination; --, not available; $<$, less than]




One method for using a long record of single-station observations to support inferences about water-quality impacts is the identification of trends. Mattawoman Creek is a component of the Chesapeake Bay NTN, a set of stations for which coefficients of the seven-parameter LOADEST model are used to infer "flow-adjusted trends" in water quality. In the interest of ensuring comparability among all NTN stations, trends for all stations are computed, reviewed and reported by NTN Program staff using consistent methodology (Langland and others, 2012). This information is periodically updated on the U.S. Geological Survey's RIM web site (http://cbrim.er.usgs. gov/) as new data become available; flow-adjusted trends were not computed or analyzed independently as a part of this study.

\section{Comparisons between Watersheds—Load Estimates}

Concentration summaries for the study period were compared earlier, but in some cases where sampling frequencies differ, for example as shown in table 1, this comparison may be biased. To control for biases, annual loadings of total nitrogen, total phosphorus and suspended sediment for the 2008 water year, representative of the 30-year normal discharge (fig. 8 b), also were compared. To facilitate comparison between watersheds of differing size, loads were normalized to basin area, and reported as yields in units of pounds per year per square mile $\left(\mathrm{lb} / \mathrm{yr} / \mathrm{mi}^{2}\right)$. Rankings of the watersheds in terms of yield estimates were generally consistent with rankings based on concentration estimates (table 8, fig. 17); in the context of the regression model that was used, and assuming a monotonic trend in the relation between constituent concentration and discharge in each watershed, this implies that sampling was representative of a broad range of flow regimes in each river. The Northwest Branch Anacostia River had the highest yields of sediment and phosphorus, and the North Branch Patapsco River had the lowest. Higher yields were reported for the Northwest Branch Anacostia River in 2005-06 (Miller and others, 2007), however, there were extensive stream restoration projects during that time period, which likely contributed to increased sediment loads. There do not appear to be any obvious point sources of phosphorus that cause significantly higher yields. The Choptank River has very low sediment yields due to its dendritic drainage patterns and lower energy in the system, with more storage of sediment in the wetland areas. Mattawoman Creek had the second highest yields of both sediment and phosphorus (380,000 and $310 \mathrm{lb} / \mathrm{yr} / \mathrm{mi}^{2}$ for water year 2008, respectively; table 8), possibly from a large supply of Coastal Plain sand that is transported in the trellised watershed.

Gellis and others (2009) collected 327 samples of suspended sediment during water year 2004 at Mattawoman Creek as a part of a research study on sediment loading and source tracking. Using the USGS program Graphical Constituent Loading Analysis System (GCLAS), Gellis and others (2009) estimated total suspended-sediment yield for water year 2004 at Mattawoman to be 103,000 lb/yr/mi². Applying LOADEST to data collected during this study

Table 7. Total loading estimates and model prediction uncertainty for the period January 6-March 6, 2009, comparing LOADEST models constructed using discharge with daily data, discharge with hourly data, and discharge and turbidity with hourly data.

[Loads are expressed as an average daily flux; C.I., confidence interval; lb/d, pounds per day; --, not available; \%, percent]

\begin{tabular}{|c|c|c|c|c|c|}
\hline Time step and model terms & $\begin{array}{c}\text { Estimated } \\
\text { daily flux } \\
\text { (lb/d) }\end{array}$ & $\begin{array}{c}\text { Lower } 95 \% \\
\text { C.I. } \\
\text { (Ib/d) }\end{array}$ & $\begin{array}{c}\text { Upper 95\% } \\
\text { C.I. } \\
\text { (Ib/d) }\end{array}$ & $\begin{array}{l}\text { C.I. width } \\
\text { (lb/d) }\end{array}$ & $\begin{array}{c}\text { C.I. width } \\
\text { reduction }{ }^{1} \\
(\%)\end{array}$ \\
\hline Daily discharge & 9,500 & 2,000 & 29,000 & 27,000 & -- \\
\hline Hourly discharge & 10,000 & 6,400 & 15,000 & 8,600 & 68 \\
\hline Daily discharge & 13 & 7.4 & 20 & 13 & -- \\
\hline Hourly discharge & 13 & 10 & 16 & 6.0 & 52 \\
\hline Hourly discharge and turbidity & 12 & 10 & 13 & 3.0 & 76 \\
\hline \multicolumn{6}{|c|}{ Total nitrogen } \\
\hline
\end{tabular}

\footnotetext{
${ }^{1}$ Relative to the estimate based on daily discharge.
} 

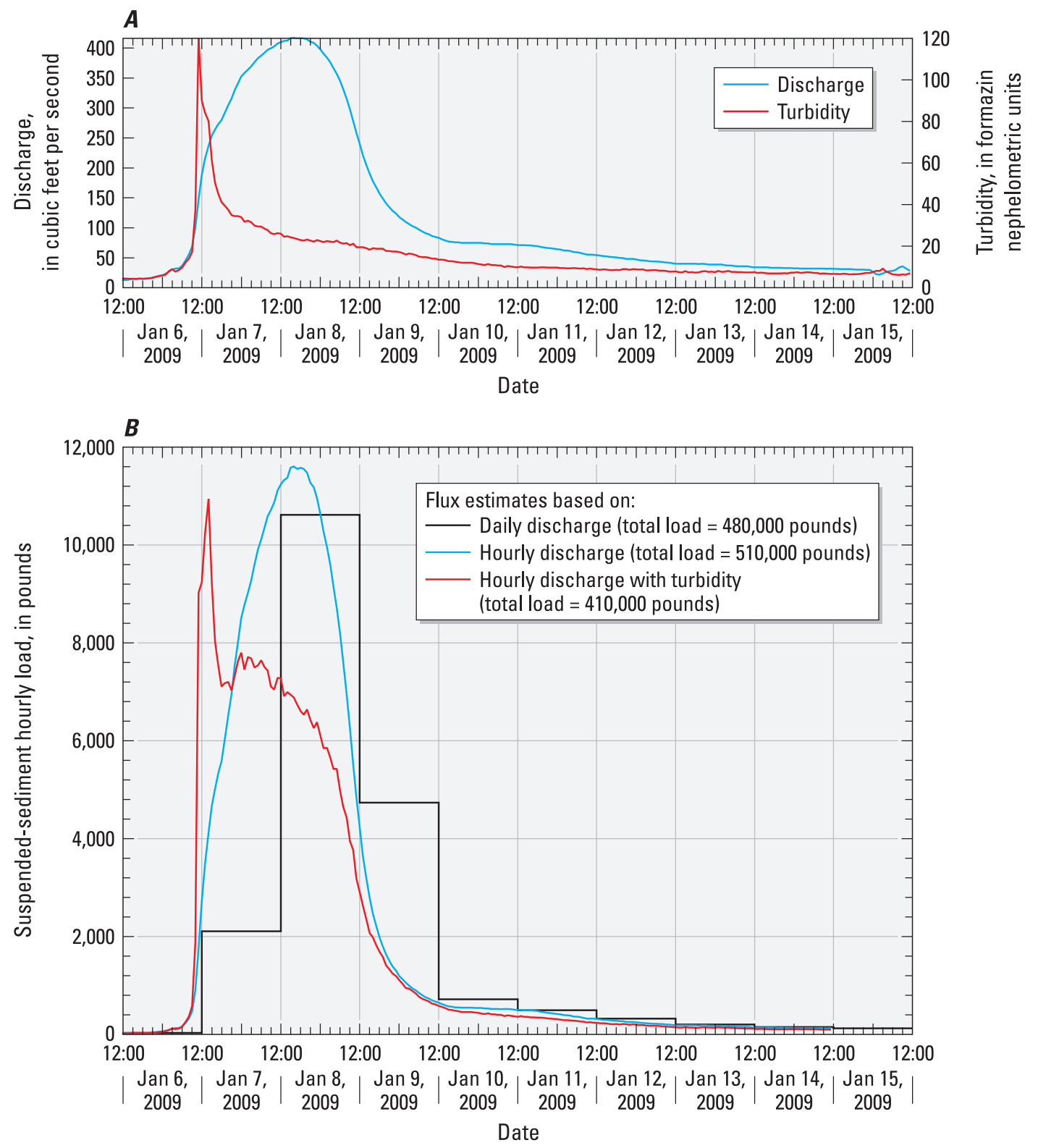

Figure 22. Time series of discharge, turbidity, and LOADEST estimates of suspended-sediment flux for a 10-day period in January 2009 comparing time series of load estimates based on a daily model with discharge, an hourly model with discharge, and an hourly model with discharge and turbidity $(A)$ discharge and turbidity, and (B) load estimates.

results in an estimate of roughly $370,000 \mathrm{lb} / \mathrm{yr} / \mathrm{mi}^{2}$ for water year $2004(55,000 \mathrm{lb} / \mathrm{d}$; table 5), which is between three and four times the estimate of Gellis and others (2009). The discrepancy likely results from several factors: the first is the density of samples and corresponding method for load estimation. Gellis and others (2009) conducted high-frequency sampling of most of the major storm events that occurred during water year 2004, resulting in a finely resolved characterization of the variability in suspended-sediment concentration over the course of each storm. In particular, they accurately characterized hysteretic effects; that is, the tendency for suspended-sediment concentration on the rising limb of a discharge hydrograph to be higher than that at the equivalent discharge on the receding limb (fig. 22). The GCLAS loadestimation program is appropriate for such a densely sampled short-term research study. In contrast, only 38 samples were collected in water year 2004 as a part of this study. LOADEST is best suited for characterizing inter-annual variability, detecting long-term trends, and comparing watersheds, because it uses sampling programs that span a long period but are 
comparatively sparse in any given year. Among the disadvantages of using the seven-parameter regression model in LOADEST is the inability to represent hysteretic effects (fig. 22); this likely contributes to overestimation, as evident in the comparison of the seven- and eight-parameter models presented in table 7.

Differences in sampler location also likely contribute to the discrepancy between water year 2004 loading estimates in this study and those of Gellis and others (2009). To decrease the potential influence of lateral gradients in water quality associated with time-varying inflows from Old Womans Run, Gellis and others located their sampler intake midchannel, roughly $300 \mathrm{ft}$ downstream of the location of the equipment deployed at LEW for this study. As discussed in the Comparison between Watersheds - Concentration Data section, a limited record of differences between turbidity recorded by the operational sonde deployed at LEW throughout this study and the temporary sonde deployed in 2011 indicates that turbidity and, by inference, particulate constituent concentration in discrete samples collected at LEW is biased high relative to concentrations in the Mattawoman main stem; these differences tend to appear in association with storm events (fig. 7b). Quantitative estimation of the corresponding difference in load would require development of separate regression models for the LEW and temporary sonde data; this was not possible given the limited comparison period. Thus, separation of the effects of study design and sampler location on the large difference in sediment loading estimates between this study and that of Gellis and others (2009) is not possible. Because Gellis and others (2009) sampled at a much higher frequency and sampled a presumably better-mixed location (mid-channel about $300 \mathrm{ft}$ downstream from the mouth of Old Womans Run), their lower estimate is probably more indicative of the actual sediment load from the Mattawoman watershed for water year 2004. The degree to which the data collected in this study lead to overestimates for other years, as well as the degree to which annual loads of nitrogen and phosphorus shown in tables 5 and 8 may also be overestimated, cannot be determined using the available data.

The North Branch Patapsco River had the highest yield of total nitrogen, and Mattawoman Creek had the lowest (table 8). Since total nitrogen, like total phosphorus, was best predicted by turbidity (table 4 ), the same potential for overestimation due to sampling bias outlined above for sediment and phosphorus applies here; in this case, however, the inaccuracy results in a more favorable comparison. As discussed earlier for the concentration data, the low nitrogen yield is likely due to the configuration of the Mattawoman flood plain as a zone that is highly favorable to denitrification; lower overall loading of nitrogen from the watershed may also play a role.

Table 8. Annual yields of suspended sediment, total nitrogen, and total phosphorus for the 2008 water year (0ctober 1, 2007September 30, 2008) for Mattawoman Creek, four comparison watersheds, and the Potomac River.

[USGS, U.S. Geological Survey; \%, percent; lb/yr/mi², pounds per year per square mile]

\begin{tabular}{|c|c|c|c|c|}
\hline & \multirow{2}{*}{$\begin{array}{l}\text { Predominant } \\
\text { land cover }\end{array}$} & \multicolumn{3}{|c|}{$\begin{array}{l}\text { Annual yields with } 95 \% \text { confidence intervals } \\
\qquad\left(\mathrm{lb} / \mathrm{yr} / \mathrm{mi}^{2}\right)^{2}\end{array}$} \\
\hline & & $\begin{array}{c}\text { Suspended } \\
\text { sediment }^{3}\end{array}$ & $\begin{array}{c}\text { Total } \\
\text { nitrogen }\end{array}$ & $\begin{array}{c}\text { Total } \\
\text { phosphorus }\end{array}$ \\
\hline Mattawoman Creek near Pomonkey, Md. ${ }^{4}$ & Forest, urban, wetland & $\begin{array}{c}380,000 \\
(120,000-910,000)\end{array}$ & $\begin{array}{c}2,100 \\
(1,800-2,500)\end{array}$ & $\begin{array}{c}310 \\
(220-430)\end{array}$ \\
\hline $\begin{array}{l}\text { Northwest Branch Anacostia River near } \\
\text { Hyattsville, Md. }\end{array}$ & Urban & $\begin{array}{c}800,000 \\
(290,000-1,700,000)\end{array}$ & $\begin{array}{c}4,700 \\
(4,000-5,400)\end{array}$ & $\begin{array}{c}570 \\
(360-910)\end{array}$ \\
\hline Choptank River near Greensboro, Md. & Agriculture, wetlands & $\begin{array}{c}25,000 \\
(17,000-34,000)\end{array}$ & $\begin{array}{c}3,000 \\
(2,700-3,100)\end{array}$ & $\begin{array}{c}160 \\
(140-180)\end{array}$ \\
\hline Georges Creek at Franklin, Md. & Forest & $\begin{array}{c}160,000 \\
(110,000-230,000)\end{array}$ & $\begin{array}{c}3,800 \\
(3,300-4,300)\end{array}$ & $\begin{array}{c}190 \\
(140-250)\end{array}$ \\
\hline North Branch Patapsco River at Cedarhurst, Md. & $\begin{array}{l}\text { Agriculture, forest, } \\
\text { urban }\end{array}$ & $\begin{array}{c}130,000 \\
(26,000-420,000)\end{array}$ & $\begin{array}{c}6,900 \\
(6,900-7,400)\end{array}$ & $\begin{array}{c}130 \\
(74-210)\end{array}$ \\
\hline
\end{tabular}

${ }^{1}$ (Fry and others, 2011); refer to table 1 for percentage of land cover.

2 (Langland and others, 2012); lower and upper 95-percent confidence intervals are in parentheses.

${ }^{3}$ Water-column sediment was measured by USGS as suspended-sediment concentration (SSC) for Mattawoman Creek, Northwest Branch Anacostia River, Choptank River, and Potomac River at Chain Bridge, and by the Maryland Department of Natural Resources as both total suspended solids and SSC for Georges Creek and North Branch Patapsco River; refer to table 1 for details.

\footnotetext{
${ }^{4}$ Quality-control data collected in 2011 indicate that reported annual fluxes of sediment and particulate nutrients at Mattawoman Creek may be overestimates; see section Comparisons between Watersheds-Load Data for discussion.
} 
Flood-plain denitrification may also at least partially explain the differences between nitrogen yields in the Choptank and North Branch Patapsco Rivers. These two watersheds have very similar percentages of land cover in agriculture, but have a very different occurrence of nitrogen in the streams. The topography in the Patapsco River is steeper and better-drained, whereas the Choptank River has a higher percentage of wetlands where reducing conditions can develop.

\section{Limitations of Analysis}

Some elements of the interpretation provided herein were limited by QA issues associated with location of the autosampler and continuous water-quality sonde at LEW immediately downstream of, and on the same side of Mattawoman Creek as the mouth of Old Womans Run, a tributary draining roughly 10 percent of the total gaged area. Lateral gradients in water quality resulting from this sampling configuration (1) limited the interpretability of both continuous and discrete data on the time scale of individual storm events (for example, figure 6 and accompanying discussion in Evaluation of Data Integrity - Lateral Mixing), (2) yielded data that were at times representative of conditions in the Mattawoman Creek main stem, and at other times more representative of conditions in Old Womans Run; this ambiguity confounds the discrimination of the water-quality effects of land-use change in the greater Mattawoman watershed from the effects of land-use change in the Old Womans Run watershed (figs. 1 and 2), (3) likely introduced additional scatter into empirical regression relations between discretely sampled constituents and continuous surrogates (for example, figures 18-20 and accompanying discussion in Estimation of Continuous Concentrations of Nutrients and Suspended Sediment), and (4) introduced incompletely characterized, but potentially substantial, biases into estimates of downstream loading (for example, figure 7, tables 5 and 8, and discussion in Comparisons between Watersheds-Load Estimates). All of these limitations could be remedied by relocating the gage and water-quality instrumentation to a site where more complete lateral mixing could be assured, or by collecting all samples using EWI techniques.

\section{Summary and Conclusions}

Discharge and water-quality data, consisting of both discrete samples and continuous measurements collected at Mattawoman Creek over a 10-year period beginning in October 2000 and ending in January 2011 were summarized and interpreted. The monitoring, conducted in cooperation with the Charles County (Maryland) Department of Planning and Growth Management, the Maryland Department of the Environment, and the Maryland Geological Survey, was undertaken with the goals of describing ambient water quality, identifying potential contaminant sources, and quantifying nutrient and sediment loads to the tidal freshwater Mattawoman estuary. In spite of data limitations associated with sampling location and resulting complications in interpretation, both the discrete and continuous data yielded a number of robust and meaningful insights into water-quality conditions at Mattawoman Creek. Of all the data collected, seasonal and episodic patterns in specific conductance provide the strongest evidence of water-quality impacts caused by human activity in the Mattawoman watershed. The data show that the highest median concentrations occurred during the winter months, with monthly median concentrations decreasing throughout the spring, summer, and fall; episodic extremes in winter reflected enrichment, whereas those in summer reflected dilution. All of these observations are consistent with the application of de-icing compounds to roads in winter. As of the end of the study period (January 2011), salinity levels at Mattawoman Creek show a modest impact relative to that inferred from similar records at U.S. Geological Survey monitoring locations in and around Washington, D.C. However, the evidence of both episodic and seasonal influences on specific conductance in stream water implies the existence of both rapid and delayed pathways for other development-related contaminants to reach the stream.

Total nitrogen concentrations and yields at Mattawoman Creek were the lowest of those reported among five basins of similar size, distributed throughout Maryland, with comparable records. This is likely due partly to the denitrification capacity of the flood plain; lower nitrogen loading from the watershed, relative to the other more heavily agricultural comparison watersheds, might also play a role. Concentrations and yields of suspended sediment and total phosphorus were comparatively high, exceeded only by those observed in the highly urbanized Northwest Branch Anacostia River; however, several lines of evidence indicate that the concentrations of these constituents measured at left-edge water are biased upward, relative to concentrations in the Mattawoman main stem. Any bias in measured concentration will influence flux estimates in the same direction. Comparison basins were selected on the basis of their size, the availability of data of comparable length, and representativeness of flow conditions. Between-station differences in sampling frequency and protocol may influence comparison of both concentrations and loads. Regional factors such as watershed lithology can significantly influence sediment and nutrient fluxes, both in terms of the expectation for undeveloped conditions, as well as the response to land-use change. Thus, while the comparisons provide a degree of regional context for the conditions observed at Mattawoman, rankings of concentrations and loads should not be taken as an indication of the degree of human influence relative to local pre-development conditions at Mattawoman Creek, compared to human influence in the other watersheds.

The data were also examined in terms of consistency with general expectations related to land use. Although far from conclusive, the Mattawoman data show several features and patterns that are indicative of a functioning forested stream ecosystem. The stream is well-oxygenated with no evidence 
of excessive seasonal oxygen demand. Evidence of a small suspended-sediment subsidy in spring is consistent with increased frequency of overbank flows, promoting interaction with the channel banks and flood plain during those months; moreover, sediment source fingerprinting conducted in an earlier study indicates that the streambanks and forest floor are the predominant sources of suspended sediment. The dominant form of nitrogen is the dissolved organic fraction, consistent with a forested land cover, and in sharp contrast to the heavily agricultural North Branch Patapsco River, overwhelmingly dominated by dissolved inorganic nitrogen, or the urbanized Northwest Branch Anacostia River, dominated by inorganic and particulate nitrogen. Seasonal patterns in the speciation of both nitrogen and phosphorus are consistent with demand and transformation by aquatic and terrestrial biota during the growing season, and with the input of leaf litter in the fall. None of these patterns rule out the presence of significant development-related impacts on nutrient and sediment concentrations in Mattawoman Creek; however, they provide at least circumstantial evidence that some elements of a functioning stream ecosystem remain intact.

Stepwise regression models, relating concentrations of suspended sediment, total phosphorus, and total nitrogen in discrete water-quality samples to continuously measured surrogates, identified turbidity and, in the case of suspended sediment, turbidity and discharge as the strongest predictors. For the same response variables, incorporation of turbidity as an additional parameter in the LOADEST loading model, which is typically based on only discharge, season, and time, decreased model residual variance by over a factor of two. Estimates of total sediment and nutrient flux based on hourly data for a single 58-day period were consistently lower for LOADEST models that incorporated turbidity, relative to models that did not. The observed improvements in model performance, and overall lower loading estimates, are consistent with findings of other comparative studies that incorporated turbidity in water-quality load and trend analyses.

In the absence of significant change in de-icing practices in the watershed, long-term continuous monitoring of specific conductance would provide a useful and inexpensive indication of the effects of increased development on water quality. The conductance values reached in winter episodic extremes, for example the 90th percentile of continuous observations in February, would serve as a good indicator of the degree to which road salt applied in any given year is influencing stream chemistry; of course, such an indicator would fluctuate year-to-year according to the amount of winter precipitation and aggressiveness of de-icing measures. Year-to-year trends in specific conductance values during low flow, such as the median of continuous observations in a low-flow month such as July, or the median value for all continuous observations when flow is less than 10 cubic feet per second, would provide an indication of the degree that de-icing agents applied to the surface in winter are reaching the water table and influencing groundwater chemistry.

\section{Acknowledgments}

Joel Blomquist, John Jastram, and Judith Denver of USGS, along with Karen Wiggen of the Charles County Department of Planning and Growth Management, provided thoughtful technical review comments that greatly improved the manuscript. Greg Noe of USGS and Paul Bukaveckas of Virginia Commonwealth University provided helpful commentary on nutrient data. Mitchell Donovan of USGS assisted with maps, Valerie Gaine of USGS provided a helpful editorial review, and Timothy Auer of USGS assisted with graphics and publication layout.

\section{References Cited}

Allen, J.D., 1995, Stream ecology structure and function of running waters: Philadelphia, Pennsylvania, Chapman and Hall, 388 p.

Ator, S.W., Brakebill, J.W., and Blomquist, J.D., 2011, Sources, fate, and transport of nitrogen and phosphorus in the Chesapeake Bay watershed: An empirical model: U.S. Geological Survey Scientific Investigations Report 20115167, 27 p. (also available online at http://pubs.usgs.gov/ sir/2011/5167/).

Ator, S.W., Denver, J.M., Krantz, D.E., Newell, W.L., and Martucci, S.K., 2005, A surficial hydrogeologic framework for the Mid-Atlantic Coastal Plain: U.S. Geological Survey Professional Paper 1680, 44 p., 4 pls. (also available online at $h t t p: / / p u b s . u s g s . g o v / p p / 2005 / p p 1680 /)$.

Böhlke, J.K., and Denver, J.M., 1995, Combined use of groundwater dating, chemical, and isotopic analyses to resolve the history and fate of nitrate contamination in two agricultural watersheds, Atlantic Coastal Plain, Maryland: Water Resources Research, v. 31, no. 9, p. 2,319-2,339, DOI:10.1029/95WR01584.

Charles County Department of Planning and Growth Management, 2006, Comprehensive water and sewer plan: La Plata, Maryland, Charles County Government, 223 p.

Chesapeake Bay Program, 2004, Establishing a Chesapeake Bay Nontidal Watershed Water-Quality Network: Annapolis, Maryland, Report of the Nontidal Water Quality Monitoring Workgroup, Chesapeake Bay Program, 28 p.

Christensen, V.G., 2001, Characterization of surface-water quality based on real-time monitoring and regression analysis, Quivira National Wildlife Refuge, south-central Kansas, December 1998 through June 2001:

U.S. Geological Survey Water-Resources Investigations Report 01-4248, 28 p. 
Christensen, V.G., Jian, X., and Ziegler, A.C., 2000, Regression analysis and real-time water-quality monitoring to estimate constituent concentrations, loads, and yields in the Little Arkansas River, south-central Kansas, 1995-99: U.S. Geological Survey Water-Resources Investigations Report 00-4126, 36 p.

Cohn, T.A. 1988, Adjusted maximum likelihood estimation of the moments of lognormal populations from type I censored samples: U.S. Geological Survey Open-File Report 88-350, $34 \mathrm{p}$.

Cohn, T.A., 2005, Estimating contaminant loads in rivers: An application of adjusted maximum likelihood to type 1 censored data: Water Resources Research, v. 41, W07003, DOI:10.1029/2004WE003833, 13 p.

Cohn, T.A., Caulder, D.L., Gilroy, E.J., Zynjuk, L.D., and Summers, R.M., 1992, The validity of a simple statistical model for estimating fluvial constituent loads-An empirical study involving nutrient loads entering Chesapeake Bay: Water Resources Research, v. 28, no. 9, p. 2,353-2,363.

Denny, C., 2009, Maryland's Mattawoman Creek—Protecting an extraordinary place: Annapolis, Maryland, Chesapeake Bay Foundation Save the Bay Magazine, v. 35, no. 1, p. 6-9.

Duan, N., 1983, Smearing estimate: A nonparametric retransformation method: Journal of the American Statistical Association, v. 78, no. 383, p. 605-610.

Feller, M.C., 2009, Deforestation and nutrient loading to fresh waters, in Likens, G.E., ed., Encyclopedia of Inland Waters: Boston, Massachusetts, Elsevier, p. 832-851.

Fishman, M.J., ed., 1993, Methods of analysis by the U.S. Geological Survey National Water Quality LaboratoryDetermination of inorganic and organic constituents in water and fluvial sediments: U.S. Geological Survey OpenFile Report 93-125, 217 p.

Fry, J., Xian, G., Jin, S., Dewitz, J., Homer, C., Yang, L., Barnes, C., Herold, N., and Wickham, J., 2011, Completion of the 2006 National Land Cover Database for the conterminous United States: Photogrammatic Engineering and Remote Sensing, v. 77 , no. 9, p. 858-864.

Gellis, A.C., Hupp, C.R., Pavich, M.J., Landwehr, J.M., Banks, W.S.L., Hubbard, B.E., Langland, M.J., Ritchie, J.C., and Reuter, J.M., 2009, Sources, transport, and storage of sediment in the Chesapeake Bay watershed: U.S. Geological Survey Scientific Investigations Report 20085186, 95 p. (also available online at http://pubs.usgs.gov/ sir/2008/5186/).
Glaser, J.D., 2003, Geologic map of Prince George's County: Maryland Geological Survey Map, 1 sheet, scale 1:62,500.

Hack, J.T., 1955, Geology of the Brandywine area and origin of the upland of southern Maryland: U.S. Geological Survey Professional Paper 267-A, 43 p.

Hall, L.W., Jr., Fischer, S.A., Killen, W.D., Ziegenfuss, M.C., Anderson, R.D., and Klauda, R.J., 1993, Assessing the relationship between critical acidic conditions in Maryland coastal plain streams and predicted mortality of early life stages of migratory fish: Aquatic Toxicology, v. 26, nos. 3-4, p. 239-272, http://dx.doi. org/10.1016/0166-445X(93)90033-W.

Hall, R.L., and Mathews, E.D., 1974, Soil survey of Charles County, Maryland: U.S. Department of Agriculture, Soil Conservation Service, $94 \mathrm{p}$.

Helsel, D.R., and Hirsch, R.M., 1992, Statistical Methods in Water Research: Amsterdam, Elsevier, 529 p.

Herlihy, A.T., Stoddard, J.L., and Johnson, C.B., 1998, The relationship between stream chemistry and watershed land cover data in the Mid-Atlantic region, U.S: Water, Air, and Soil Pollution, v. 105, nos. 1-2, p. 377-386.

Jastram, J.D., Moyer, D.L., and Hyer, K.E., 2009, A comparison of turbidity-based and streamflow-based estimates of suspended-sediment concentrations in three Chesapeake Bay tributaries: U.S. Geological Survey Scientific Investigations Report 2009-5165, 37 p. (also available online at http://pubs.usgs.gov/sir/2009/5165/).

Jordan, T.E., Correll, D.L., and Weller, D.E., 2000, Mattawoman Creek watershed: Nutrient and sediment dynamics, Final Report, Smithsonian Environmental Research Center, 45 p. plus appendixes, accessed August 15, 2012 at http://www.charlescountymd.gov/sites/default/ files/pgm/planning/mattawoman_sedimentreport.pdf.

Jorgensen, N.O.B., 2009, Organic nitrogen, in Likens, G.E., ed., Encyclopedia of inland waters: Boston, Massachusetts, Elsevier, p. 832-851.

Kaushal, S.S., Groffman, P.M., Likens, G.E., Belt, K.T., Stack, W.P., Kelly, V.R., Band, L.E., and Fisher, G.T., 2005, Increased salinization of fresh water in the northeastern United States: Proceedings of the National Academy of Sciences of the United States of America, v. 102, no. 38, p. 13,517-13,520. 
Krantz, D.E., and Powars, D.S., 2000, Hydrogeologic setting and potential for denitrification in ground water, Coastal Plain of Southern Maryland: U.S. Geological Survey WaterResources Investigations Report 00-4051, 24 p.

Langland, M.J., Blomquist, J.D., Moyer, D.L., and Hyer, K.E., 2012, Nutrient and suspended-sediment trends and yields and indicator development of streamwater quality conditions at nontidal sites in the Chesapeake Bay watershed, 1985-2010: U.S. Geological Survey Scientific Investigations Report 2012-5093, 26 p. (also available online at $h t t p: / /$ pubs.er.usgs.gov/publication/sir20125093).

Langland, M.J., Raffensperger, J.P., Moyer, D.L., Landwehr, J.M., and Schwarz, G.E., 2006, Changes in streamflow and water quality in selected nontidal basins in the Chesapeake Bay watershed, 1985-2004: U.S. Geological Survey Scientific Investigations Report 2006-5178, 75 p. plus appendixes (on CD), (also available online at $h t t p: / / p u b s$. usgs.gov/sir/2006/5178/).

Lorenz, D.L., and others, 2011, USGS library for S-PLUS for Windows-Release 4.0: U.S. Geological Survey Open-File Report 2011-1130 (also available online at $h t t p: / / w a t e r$. usgs.gov/software/S-PLUS/).

Maryland Department of the Environment, 2004, Mattawoman Creek Nutrient TMDL: Baltimore, Maryland, 30 p., plus appendixes.

Matsubayashi, U., Velasquez, G., and Takagi, F., 1993, Hydrograph separation and flow-analysis by specific electrical conductance of water: Journal of Hydrology, v. 152, nos. 1-4, p. 179-199.

McCartan, L., 1989, Geologic map of Charles County: Maryland Geological Survey Map, 1 sheet, scale 1:62500.

Miller, C.V., Gutiérrez-Magness, A.L., Feit Majedi, B.L., and Foster, G.D., 2007, Water quality in the upper Anacostia River, Maryland: Continuous and discrete monitoring with simulations to estimate concentrations and yields, 2003-05: U.S. Geological Survey Scientific Investigations Report 2007-5142, 43 p. (also available online at http://pubs.usgs. gov/sir/2007/5142/).

National Atmospheric Deposition Program (NRSP-3), 2011, Deposition isopleth maps for 2009, NADP Program Office, Champaign, Illinois, accessed November 7, 2011 at http:// nadp.sws.uiuc.edu/maps/Default.aspx.
National Climatic Data Center, 2002a, Climatography of the United States No. 85, divisional normals and standard deviations of temperature, precipitation, and heating and cooling degree days 1971-2000, Section 1-temperature: Asheville, North Carolina, $71 \mathrm{p}$.

National Climatic Data Center, 2002b, Climatography of the United States No. 85, divisional normals and standard deviations of temperature, precipitation, and heating and cooling degree days 1971-2000, Section 2-precipitation: Asheville, North Carolina, 69 p.

Noe, G.B., and Hupp, C.R., 2007, Seasonal variation in nutrient retention during inundation of a short-hydroperiod floodplain: River Research and Applications, v. 23, p. 1,088-1,101, DOI: 10.1002/rra.1035.

Omernik, J.M., Griffith, G.E., Irish, J.T., and Johnson, C.B., 1988, Total alkalinity of surface waters: Corvallis, Oregon, U.S. Environmental Protection Agency, Environmental Research Laboratory, single-page map, accessed August 15, 2012 at http://water.usgs.gov/owq/alkus.pdf.

Patton, C.J., and Kryskalla, J.R., 2003, Methods of analysis by the U.S. Geological Survey National Water Quality Laboratory-Evaluation of alkaline persulfate digestion as an alternative to Kjeldahl digestion for determination of total and dissolved nitrogen and phosphorus in water: U.S. Geological Survey Water-Resources Investigations Report 03-4174, 40 p., accessed July 15, 2012 at http://nwql.usgs. gov/Public/pubs/WRIR03-4174/WRIR03-4174.html.

Patton, C.J., and Truitt, E.P., 2000, Methods of analysis by the U.S. Geological Survey National Water Quality Laboratory-Determination of ammonium plus organic nitrogen by a Kjeldahl digestion method and an automated photometric finish that includes digest cleanup by gas diffusion: U.S. Geological Survey Open-File Report 00-170, 31 p., accessed July 15, 2012 at http://nwql.usgs.gov/Public/ pubs/OFR00-170/OFR00-170.html.

Paul, M.J., and Meyer, J.L., 2001, Streams in the urban landscape: Annual Reviews of Ecology and Systematics, v. 32, p. 333-365.

Phillips, P.J., and Bachman, L.J., 1996, Hydrologic landscapes on the Delmarva Peninsula, Part 1-Drainage basin type and base-flow chemistry: Journal of the American Water Resources Association, v. 32, no. 4, p. 767-778. 
Rantz, S.E., and others, 1982, Measurement and computation of streamflow, volume 1. Measurement of stage and discharge: U.S. Geological Survey Water Supply Paper 2175, 284 p. (also available online at http://pubs.usgs.gov/wsp/ wsp2175/\#pdf.

Rasmussen, T.J., and Ziegler, A.C., 2003, Comparison and continuous estimates of fecal coliform and Escherichia coli bacteria in selected Kansas streams, May 1999 through April 2002: U.S. Geological Survey Water-Resources Investigations Report 03-4056, 80 p., accessed July 15, 2012 at http://ks.water.usgs.gov/pubs/abstracts/wrir. abstract.03-4056.html.

Rasmussen, T.J., Ziegler, A.C., and Rasmussen, P.P., 2005, Estimation of constituent concentrations, densities, loads, and yields in lower Kansas River, northeast Kansas, using regression models and continuous water-quality monitoring, January 2000 through December 2003: U.S. Geological Survey Scientific Investigations Report 2005-5165, 117 p. (also available online at http://pubs.usgs.gov/ sir/2005/5165/).

Reger, J.P., and Cleaves, E.T., 2008, Explanatory text for the physiographic map of Maryland: Maryland Geological Survey Open-File Report 08-03-1, 60 p.

Runkel, R.L., Crawford, C.G., and Cohn, T.A., 2004, Load estimator (LOADEST): A FORTRAN program for estimating constituent loads in streams and rivers: U.S. Geological Survey Techniques and Methods, book 4, chap. A5, 69 p., accessed July 15, 2012 at http://pubs.usgs.gov/tm/2005/ $\operatorname{tm} 4 A 5$.

Shreve, E.A., and Downs A.C., 2005, Quality-assurance plan for the analysis of fluvial sediment by the U.S. Geological Survey Kentucky Water Science Center Sediment Laboratory: U.S. Geological Survey Open-File Report 2005-1230, 28 p. (also available online at http://pubs.usgs. gov/of/2005/1230/).

Sommer, T.R., Harrell, W.C., and Swift, T.J., 2008, Extreme hydrologic banding in a large-river floodplain, California, U.S.A.: Hydrobiologia, v. 598, p. 409-415, DOI 10.1007/ s10750-007-9159-1.

TIBCO Corporation, 2008, TIBCO Spotfire S+ 8.1 for Windows Users ${ }^{\circledR}$ Guide: TIBCO Software Corporation, $582 \mathrm{p}$.

U.S. Army Corps of Engineers, 2003, Mattawoman Creek Watershed Management Plan, Charles County, Maryland, 40 p., plus appendixes, accessed August 15, 2012, at http:// www.charlescountymd.gov/sites/default/files/pgm/planning/ mattawoman_management_plan.pdf.
U.S. Census Bureau, 2011, State and County Quick FactsCharles County, Maryland, accessed November 7, 2011, at http://quickfacts.census.gov/qfd/states/24/24017.html.

U.S. Geological Survey, 2009, Potential bias in alkaline persulfate analysis of total nitrogen in whole water samples and recommendations for quantifying bias in whole water samples, Office of Water Quality Technical Memorandum 2009.03, accessed May 26, 2011, at http://water.usgs.gov/ admin/memo/QW/qw09.03.html.

U.S. Geological Survey, variously dated, National field manual for the collection of water-quality data: U.S. Geological Survey Techniques of Water-Resources Investigations, book 9, chaps. A1-A9, available online at http://water.usgs.gov/ owq/FieldManual/.

Walsh, C.J., Roy, A.H., Feminella, J.W., Cottingham, P.D., Groffman, P.M., and Morgan, R.P., 2005, The urban stream syndrome: current knowledge and the search for a cure: Journal of the North American Benthological Society, v. 24, no. 3, p. 706-723.

Wagner, R.J., Boulger, R.W., Jr., Oblinger, C.J., and Smith, B.E., 2006, Guidelines and standard procedures for continuous water-quality monitors: station operation, record computation, and data reporting: U.S. Geological Survey Techniques and Methods 1-D3, 96 p. (also available online at http://pubs.usgs.gov/tm/2006/tm1D3/).

Wharton, C.H., Kitchens, W.M., Pendleton, E.C., and Sipe, T.W, 1982, The ecology of bottomland hardwood swamps of the Southeast: A community profile: Washington, D.C., U.S. Fish and Wildlife Service, Biological Services Program, 134 p.

Weller, D., Jordan, T., Correll, D., and Liu, Z., 2003, Effects of land-use change on nutrient discharges from the Patuxent River watershed: Estuaries, v. 26, no. 2A, p. 244-266.

Wilhelm, F.W., 2009, Pollution of aquatic ecosystems I, in Likens, G.E., ed., Encyclopedia of inland waters: Boston, Massachusetts, Elsevier, p. 110-119.

Wilson, J.M., and Fleck, W.B., 1990, Geology and hydrologic assessment of Coastal Plain aquifers in the Waldorf Area, Charles County, Maryland: Maryland Geological Survey Report of Investigations No. 53, 138 p.

Withers, P., and Jarvie, H., 2008, Delivery and cycling of phosphorus in rivers: A review: Science of the Total Environment, v. 400, nos. 1-3, p. 379-395. 


\section{Appendix A1: Relations between Measured Water-Quality Parameters and Constituents Discussed in this Report}

Appendix A1 provides a key relating water-quality parameter codes (rows in the table) to constituents discussed in this report (columns in the table). The concentration of a constituent listed in a column heading is computed by combining parameters in that column's non-blank rows, using plus (“+”) or minus (“-”) signs indicated. For example: Nitrate (first column) = P00631 (fourth row) minus P00613 (fifth row). Waterquality parameter concentrations reported as "less than" ("“") were treated as zero in summations. 


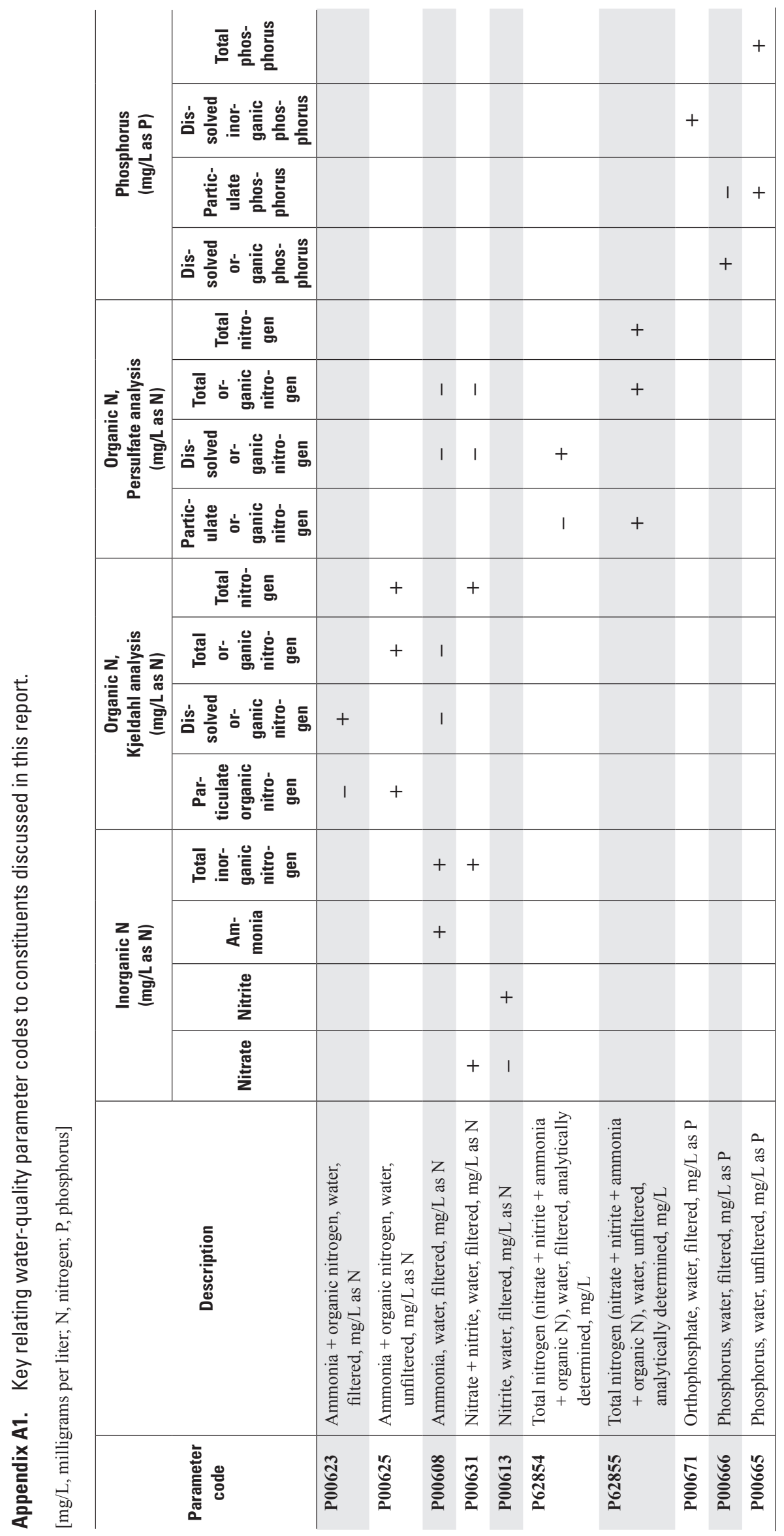


Prepared by USGS West Trenton Publishing Service Center. Edited by Valerie M. Gaine.

Graphics and layout by Timothy W. Auer.

For additional information, contact:

Director, MD-DE-DC Water Science Center

U.S. Geological Survey

5522 Research Park Drive

Baltimore, MD 21228

or visit our Web site at:

http://md.water.usgs.gov 


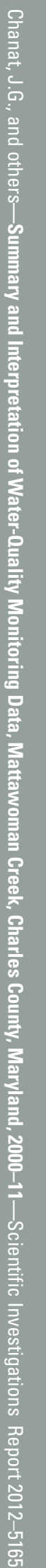

89 Printed on recycled paper

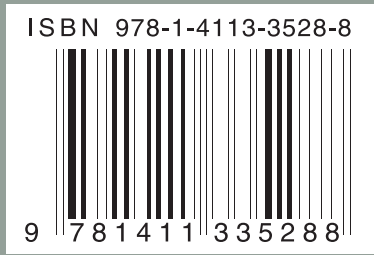

